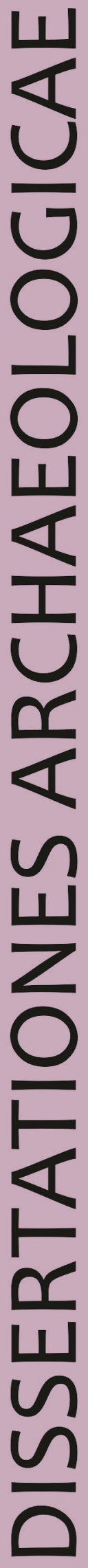

ex Instituto Archaeologico Universitatis de Rolando Eötvös nominatae
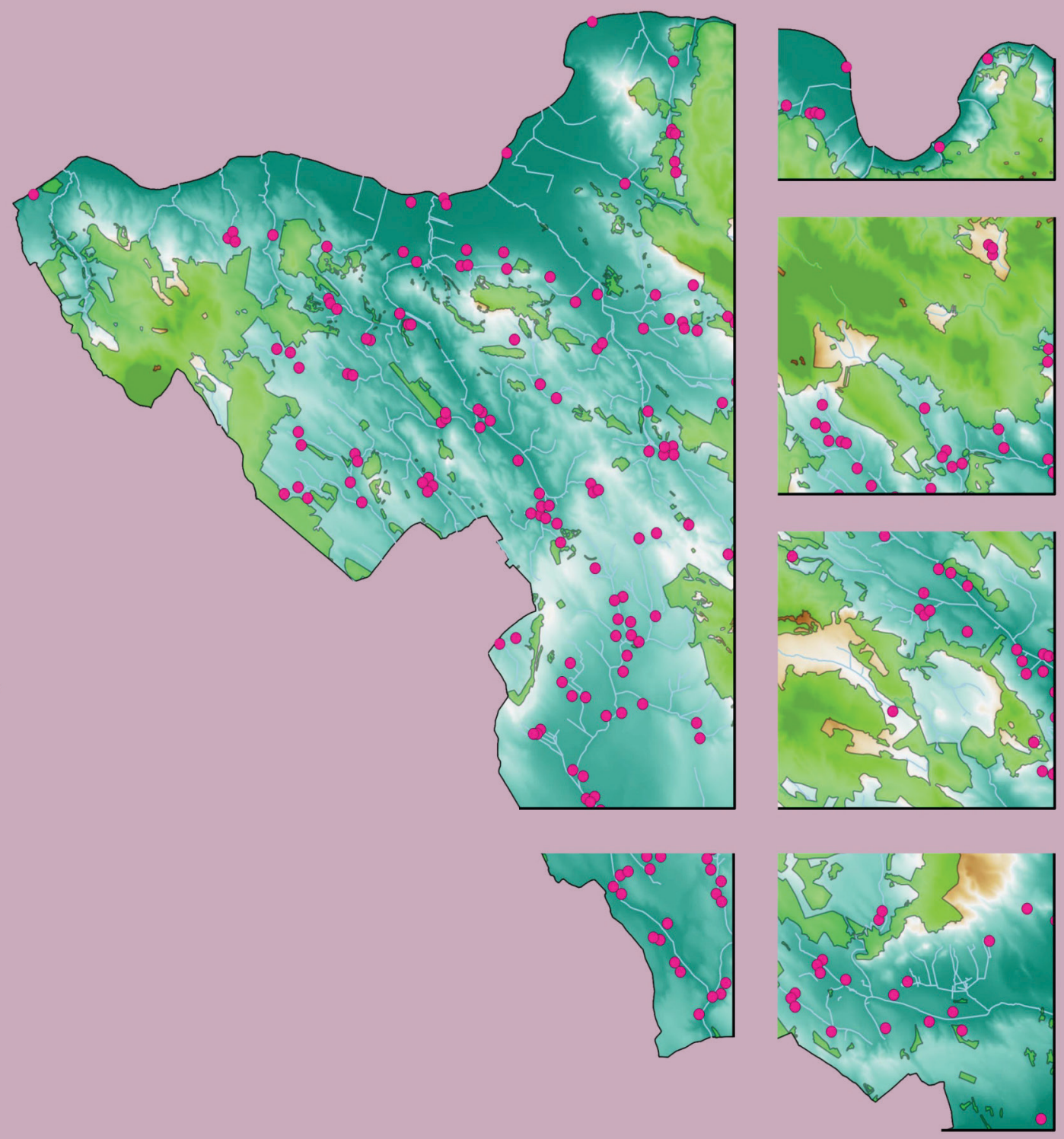

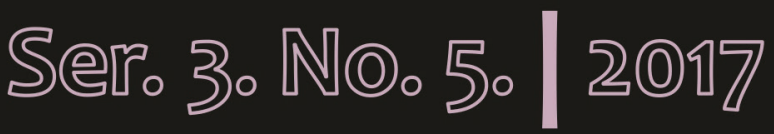




\section{Dissertationes Archaeologicae \\ ex Instituto Archaeologico}

Universitatis de Rolando Eötvös nominatae

Ser. 3. No. 5.

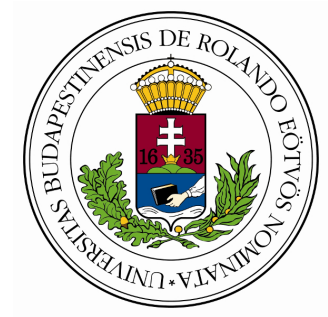

Budapest 2017 
Dissertationes Archaeologicae ex Instituto Archaeologico Universitatis de Rolando Eötvös nominatae

Ser. 3. No. 5.

Editor-in-chief:

DÁvid BARTuS

Editorial board:

LÁsZLó BARTOSIEWICZ

LÁSZLó BORHY

ZoLTÁn CZAJLIK

István FeLD

GÁBOR Kalla

PÁl RACZKY

Miklós SzABÓ

TIVADAR VIDA

Technical editors:

GÁbor VÁcZi

DÁvid BARTus

Proofreading:

SzILVIA SzÖLLősI

ZsófIA KondÉ

Available online at http://dissarch.elte.hu

Contact: dissarch@btk.elte.hu

\section{$\underline{\text { PKP }}$ \\ PUBLIC \\ KNOWLEDGE \\ PROJECT}

( Eötvös Loránd University, Institute of Archaeological Sciences

Budapest 2017 


\section{CONTENTS}

\section{ARTICLES}

András FÜZESI - Norbert FARAGÓ - Pál RACZKY

Tiszaug-Railway-station. An archaic Middle Neolithic community on the Great Hungarian Plain

Zsuzsanna Siklósi - Zsuzsanna M. VIRÁg - Viktória MozgAi - Bernadett BAJNóczi

The spread of the products and technology of metallurgy in the Carpathian Basin between 5000 and 3000 BC-Current questions

Attila KirÁLY

Grd-i Tle knapped and ground stone artefacts, excavation seasons 2016-2017

Tamás Dezső

The arrowheads from Grd-i Tle (Rania Plain, Iraqi Kurdistan)

Bence Soós

Early Iron Age burials from Tihany, Hungary

Abdullah Bakr OTHMAN

The Middle Assyrian Ceramics at Sheikhi Choli Tomb

Katalin VANDLIK

Le renard dans les fables antiques et ses représentations

Lajos JuHÁsz

Burning money - a coin hoard from Brigetio

Bence Simon

Physical landscape and settlement pattern dynamics around Aquincum and Carnuntum A socio-economic approach

Anna Herbst - Ágnes Kolláth - Gábor TomkA

Beneath the Marketplaces. Arpádian Age $\left(10^{\text {th }}-13^{\text {th }}\right.$ century) settlement traces from the city centres of Pápa and Györ, Western Hungary 


\section{FIELD REPORTS}

Zoltán Czajlik - Saša KovačEvić - Georg Tiefengraber et al.

Report on magnetometer geophysical surveys conducted in Hungary, Austria and Croatia in the framework of the Interreg Iron Age Danube project

Tamás Dezső - Gábor KAlla - Barzan Baiz IsmaIl et al.

Preliminary Report on the Hungarian Archaeological Mission (Eötvös Loránd University) at Grd-i Tle (Saruchawa) in Iraq. Second Season (2017)

Márton SzILÁGYI - Kristóf FÜLÖP - Eszter RÁKos - Nóra SzABó

Rescue excavations in the vicinity of Cserkeszölő (fász-Nagykun-Szolnok county, Hungary) in 2017

Dóra Hegy - Gergely Szoboszlay 401

Short report on the excavations in the Castle of Sátoraljaújhely in 2017

\section{Thesis Abstracts}

András RAJNA

Changes in Copper Age Networks of Connections in Light of the Material Excavated in the Danube-Tisza Interfluve

Anikó BózsA

Instruments of beauty care from the Hungarian part of Pannonia

Zsolt KöRÖSFŐI

Die Marosszentanna-Kultur in Siebenbürgen 


\title{
Early Iron Age burials from Tihany, Hungary
}

\author{
Bence Soós \\ Institute of Archaeological Sciences \\ Eötvös Loránd University \\ soos.ben94@gmail.com
}

\begin{abstract}
During 1970-72 two tumuli were excavated near the long-known prehistoric hilltop settlement of Tihany-Óvár. Its significance is reflected by the fact that it was populated from the late Urnfield period to the Hallstatt Age, hence in this sense it is comparable with the most widely known sites of the Early Iron Age in Western Hungary, such as the Somló and the Ság Hill, Szalacska, Zalaszántó, Süttő and Sopron. Contrary to them, however, no burials from Tihany have been entirely published so far. This paper aims to change this situation. The features found under Tumulus I strongly suggest that the comparison between Tihany and the aforementioned sites is well-founded based chiefly on the ceramic vessels and the remarkable structure of the barrow. On the other hand the mound seems to fit into a broader picture of the eastern Hallstatt zone with regard to the burial customs and rituals identified based on tumuli dated to the $\mathrm{Ha}$ C2D1 phases from Styria to the northeastern part of Transdanubia. Secondly, a stone-lined grave is presented. Considering the grave form and the vessels comprising the grave goods it shows an utterly different picture than Tumulus I. Consequently, a certain chronological distance between the two burials seems to be conceivable, i.e. the urn grave seems to date to the $\mathrm{Ha} C 1-\mathrm{C} 2$ phases. In addition, the example of the stone-lined grave raises the question whether other graves besides the tumuli might be reckoned with.
\end{abstract}

\section{The tumulus}

\subsection{Introduction}

In the followings I would like to present an Early Iron Age tumulus excavated during 1970 by András Uzsoki. He, set aside a brief article, never published the results, thus in my BA thesis I endeavoured to evaluate Uzsoki's findings. ${ }^{1}$ The excavations were conducted in Tihany, Veszprém County, situated on a peninsula on the northern coast of Lake Balaton (Fig. 1).

\subsection{The site: Tihany-Óvár alja}

The tumuli under the prehistoric fortification called Tihany-Óvár have been known to researchers since Flóris Rómer firstly reported about them in his letters, however, he misleadingly identified them as "kunhalom", i.e. burial mounds of the Cumans. Although Rómer was the first who labelled them as archaeological phenomena, Viktor Récsey conducted the earliest excavation at the site.

1 Bence Soós: Tihany-Óvár alja I. számú halomsírjának kerámiaanyaga. BA thesis. Eötvös Loránd University, Institute of Archaeological Sciences 2016. I am obliged to my academic advisor, Zoltán Czajlik. I would also like to express my gratitude towards Judit Regenye for her ernormous help. Furthermore, I would like to thank Ágota Perémi and Tímea Ritecz for making the finds available to me. This research was supported by the programme NRDIO 111058. 
One of the major perplexing questions regarding the tumulus cemeteries of the Hallstatt Age is how many mounds they consist of. ${ }^{2}$ As far as I know, at Tihany the first enumeration of the tumuli was made by Bálint Kuzsinszky who also published a more or less accurate map of the fortification and the barrow cemetery (Fig. 3.B) along with a brief report about his excavation at the site and a photo showing four barrows. ${ }^{3}$ In 1929 Sándor Neogrady took aerial photos of the tumuli. ${ }^{4}$ Five mounds could be identified on the pictures, and their topographical situation is ascertainable, which is enormously important because no detailed topographical survey had ever been made before the rescue excavations in 1970-72. On the other hand, Neogrády's photo helps us identifying the tumuli on the picture published by Kuzsinszky. As a result, the tumulus on the left side of the picture could be recognised as the easternmost barrow, which could be still found at the site. In our point of view, the remaining three tumuli are the ones that were demolished during the construction of the parking lot (Fig. 1).
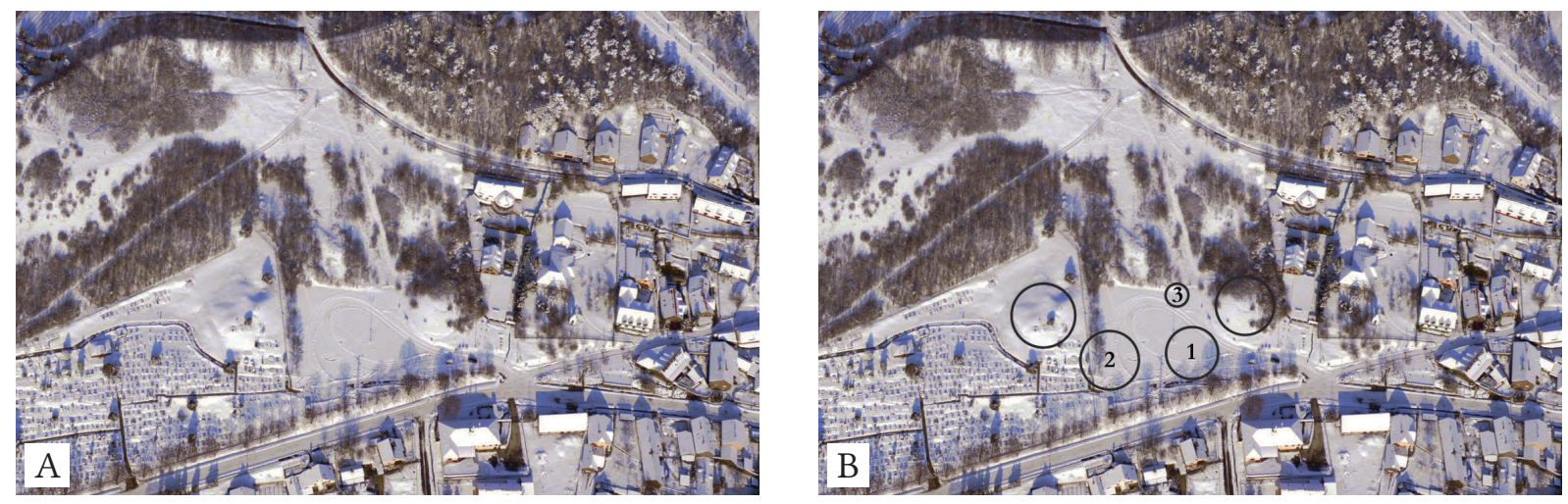

Fig. 1. A - Satellite image depicting the Tihany Peninsula, B - The ASL survey of the Tihany Peninsula. The red rectangular is marking the area covered by Fig. 2. The two still standing tumuli are to some extent visible.

An interesting feature of one of the tumuli under the fortification according to Kuzsinszky is that its top is a bit sunk in. This information could be used to identify the tumulus in question on the aerial photograph taken by Neogrady. At this point, we have to emphasise that a contradiction can be found between the topographical descriptions of the barrows made by Kuzsinszky and the photograph. According to Kuzsinszky, the tumulus in question is located in the nearby cemetery of Tihany. ${ }^{5}$ Contrarily to this, on Neogrady's photo the barrow with the sunk-in top is obviously next to the cemetery. Following this, we assume that this mound might be identified as Tumulus II of the excavation in 1970-72, because Uzsoki himself alludes to the mentioned characteristic of the barrow in question. ${ }^{6}$ Another problematic detail about the descriptions of Kuzsinszky is that he only mentions four tumuli, ${ }^{7}$ although the map of the site he published depicts five barrows.

As earlier mentioned, the first excavation at the site was conducted by Viktor Récsey in the 1890s. ${ }^{8}$ According to him, he sifted through the largest tumulus that was located the nearest

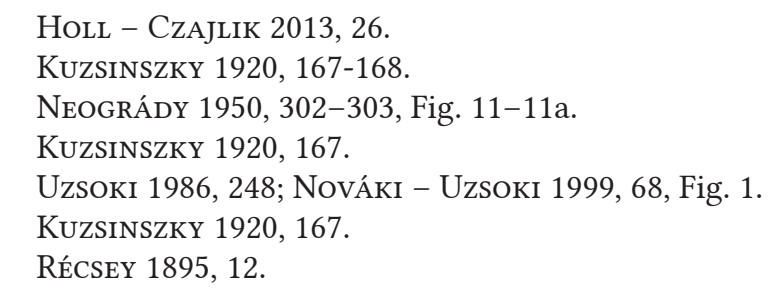




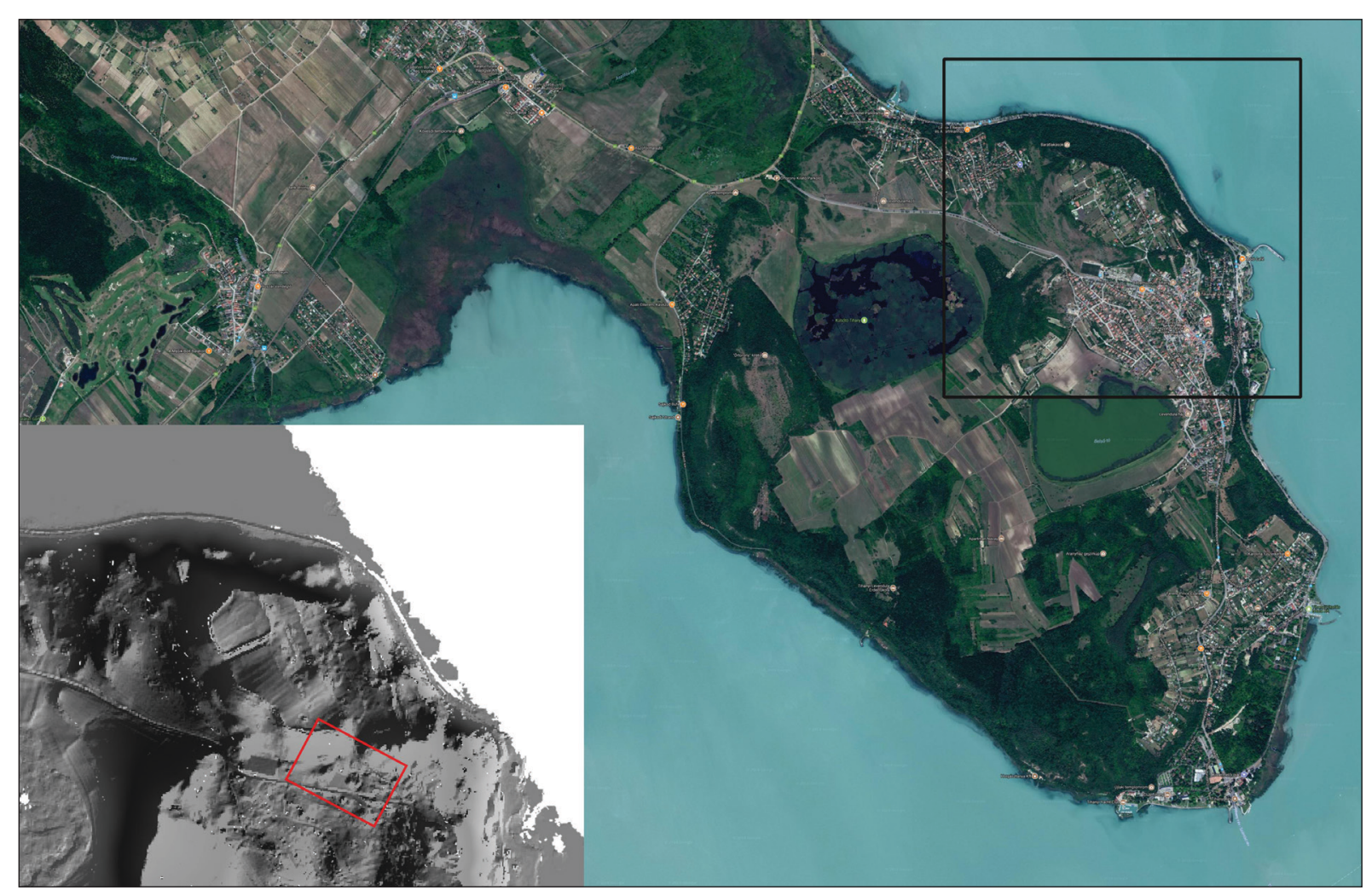

Fig. 2. Aerial photograph of the site, the circles are marking the approximate location of the tumuli according to the survey map made by Gyula Nováki and András Uzsoki (NovÁki - Uzsoki 1999, 68). The numbers are in accordance with the labels used by Uzsoki during the excavation. The tumuli are to some extent visible at each side of the parking lot even today. (The photo was taken by Zoltán Czajlik 2010.02.08.)

to the village of Tihany. Nowadays, due to the very fact that three out of the once five tumuli have been obliterated, we are not able to decide which was the "largest". On the other hand, there is another possible clue to the identification of the tumulus excavated by Récsey. According to him, he searched through the whole mound, which might suggest that the depression on the top of one of the tumuli noted by Kuzsinszky could have been the result of Récsey's work. In my personal view, the most valuable information concerning the location of the tumulus in question is that it was located nearest to the village, however, the question has to remain open.

Kuzsinszky himself also opened one of the tumuli. ${ }^{9}$ The identification of this barrow seems to be less problematic, since during the excavation in 1971, Uzsoki believed to have managed to find the traces of Kuzsinszky's trench in Tumulus I. ${ }^{10}$ This assumption is also supported by the fact that Kuzsinszky's brief description of the inner structure seems to be in accordance with Uzsoki's observations.

Since I will revert to the discussion of the details of the excavation of Tumulus I later, here I would like to briefly summarize the additional results of the rescue excavation in 1970-72. As it is shown on the map published in $1999^{11}$ (Fig. 3.A), and as we have already mentioned, Tumulus

9 Kuzsinszky 1920, 167.

10 Uzsoki 1971a, 17.

11 NovÁki - Uzsoki 1999, 68, Fig. 1. 


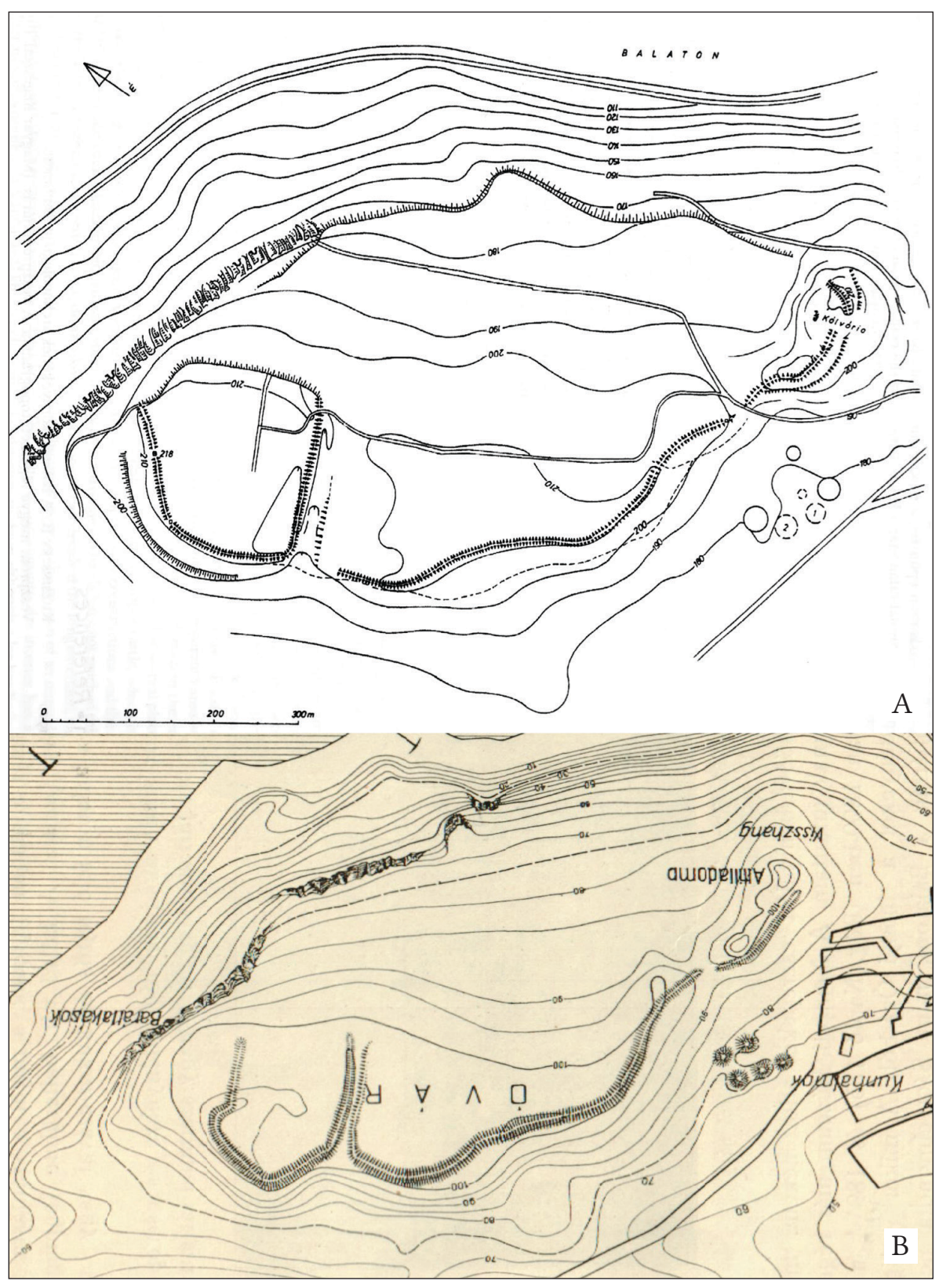

Fig. 3. A - Contour survey of the Óvár made by Gyula Nováki and András Uzsoki (NovákI - Uzsoki 1999, 68), B - Countur-map of the site published by Kuzsinszky (Kuzsinszky 1920, 168).

II was located next to the barrow in the present-day cemetery of Tihany. Uzsoki's preliminary report reads that it was $5 \mathrm{~m}$ in height and it had a diameter of $35-50 \mathrm{~m} \cdot{ }^{12}$ He noted that the mound bore two depression on its top, a characteristic feature that enables us to identify this barrow on the aerial photographs and in the descriptions of Kuzsinszky. The inner structure of this barrow appears to be obscure. The excavator tends to write about two or three beehive-form pits that contained several human remains, but he is not able to date these features.

12 It is a rather perplexing question, on which measurement of the tumuli we can rely. Kuzsinszky writes that one can reckon with a diameter of $10-15 \mathrm{~m}$ and a height of 2-3 $\mathrm{m}$ considering the tumuli. (KuZsinszKY 1920, 167) However, the topographical survey of Tihany in 1965 resulted that the mounds have a diameter of 15-20 m (ÉRI ET AL. 1969, 18) The situation gets even more problematic when we take into account that Uzsoki measured $28 \mathrm{~m}$ for the diameter and $4 \mathrm{~m}$ for the height in the case of Tumulus I. 
In addition to these pits, the mound also hid a small stone-lined grave that could be assigned to the Hallstatt Age population of the hillfort. I will be addressing this grave later in this paper.

We have to devote a few words to the tumulus labelled as third but never excavated by Uzsoki. Unfortunately, this relatively small mound had been obliterated before Uzsoki arrived at the site. Finally, we have to briefly take into account the possibility of a hitherto not identified sixth tumulus at the site. There is an aerial photo taken in 1969 that, according to Nováki and Uzsoki, indicates that a barrow might be located north of the already discussed tumuli ${ }^{13}$ (Fig. 3.A). However, it seems to be unlikely, for Sándor Neogrady's photograph shows a very clear situation with only five mounds. ${ }^{14}$ Recently, an ALS survey was conducted in the region of Lake Balaton including the Tihany Peninsula ${ }^{15}$ (Fig. 1.B), which shows no sign of further tumuli either, however, the question is still open to debate.

\subsection{The excavation of Tumulus 1}

Description:

- Tumulus: Its diameter was approximately $21 \mathrm{~m}$, its average height was around $2 \mathrm{~m}$. The mound consisted mainly of stone blocks quarried presumably in close vicinity of the cemetery. No inner structure was identified, the stones were directly covering the burial.

The rescue excavation of the mound began at the end of March in 1970 under the direction of András Uzsoki. It is worth noting that the financial background was very limited; as a result the only archaeologist present at the excavation was he alone. At the beginning of the work a contour survey of the mound was made. At this time the future four sections of the excavation in the mound were defined by two perpendicular lines with the point of intersection at the highest point of the barrow (Fig. 4).

The work began in Section I at the eastern part of the tumulus (Fig. 5). According to Uzsoki's observations the stone heap in the tumulus at its margins was $20-50 \mathrm{~cm}$ high (Fig. 5-6). Due to the erosion, the stones on the southern side of the barrow had been already visible on the surface before the excavation began. During the works in Section I, a burnt layer abounding in charcoal was found, which also yielded Early Iron Age pottery sheerds as well as calcined bones (Fig. 8). At this point a $1.5 \mathrm{~m}$ broad and $1.9 \mathrm{~m}$ deep pit became observable that was deepening into the stone packing, even cutting the burnt layer (Fig. 9). According to Uzsoki's notes, they found some ' $20^{\text {th }}$ century pottery', possibly suggesting that this pit was made during the excavation of Bálint Kuzsinszky.

After reaching the burnt layer in Section I the work continued in Section II and III, however, the size of the stones was sometimes hindering - stone blocks heavier than $100 \mathrm{~kg}$ often occured. Following the removal of the limestone heap from the surface of the burnt, charcoal-containing layer in Section I, a $4.25 \mathrm{~m}$ long and $1.4 \mathrm{~m}$ wide layer of burnt bone and pottery fragments, charcoal and ash came to light. A problematic aspect of the documentation is that the exact location of each ceramic find was not noted, as a result we cannot be sure

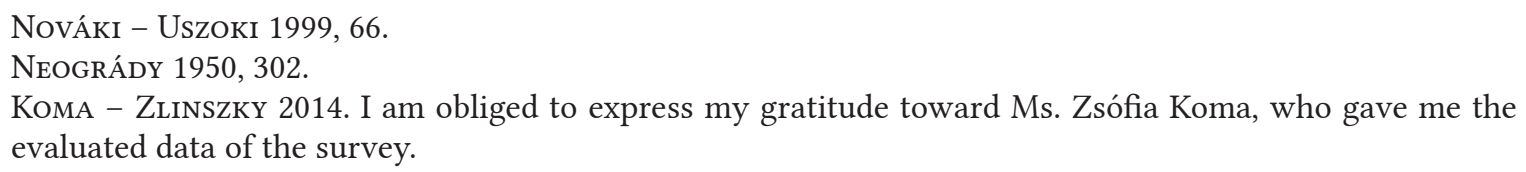




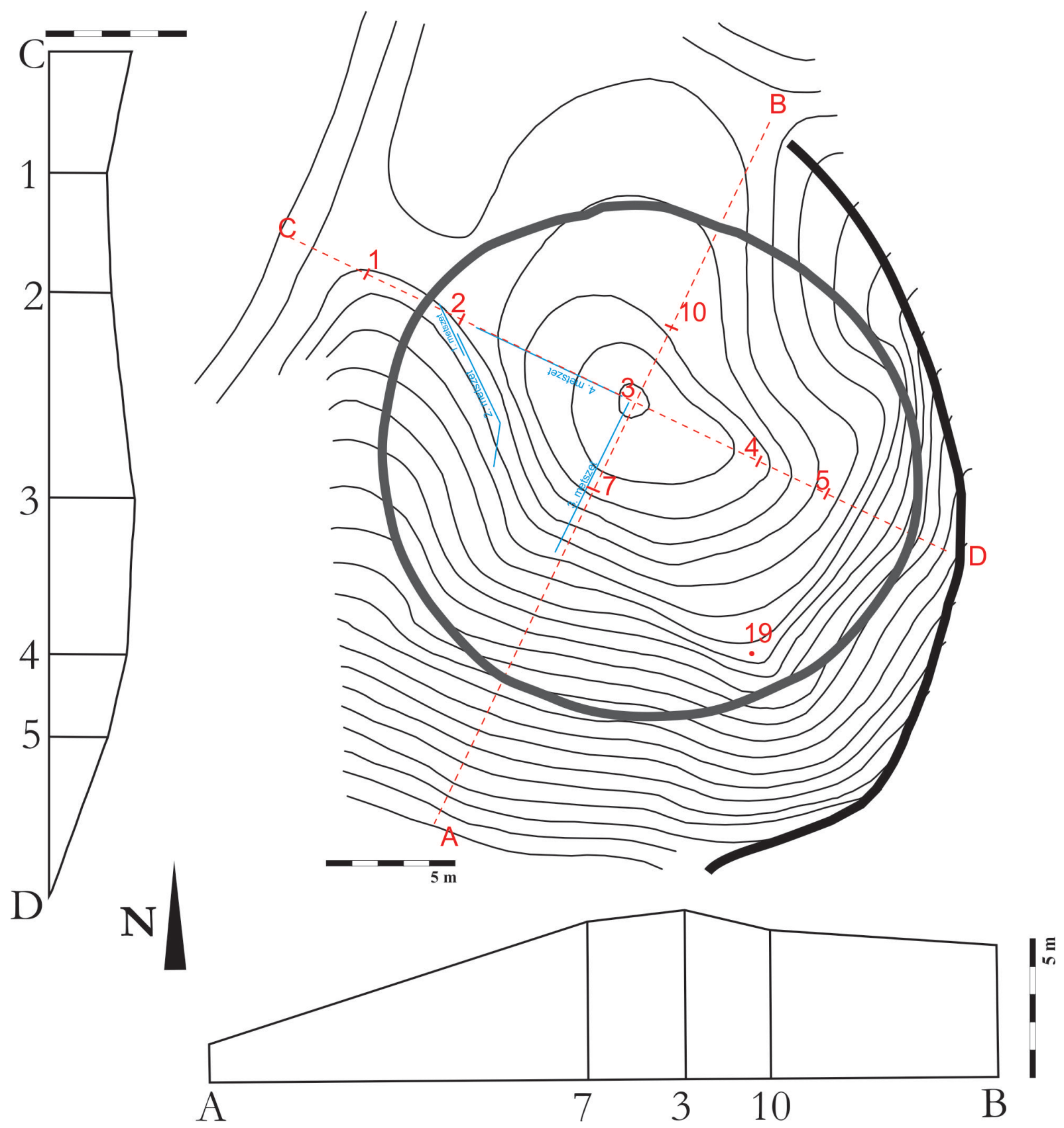

Fig. 4. Contour survey of Tumulus 1. The lines are marking the borders of the sections complemented by the lines of the profile walls. Section I between the A and C points. Section II between the C and D points. Section III between the B and D points. Section IV between the D and A points.

whether the fragments belonging to one vessel formed discrete groups in the grave or not. On the other hand, we learn from Uzsoki's notes that the sherds and the burnt bone remains were mixed. In addition, a small amount of bronze and iron fragments as well as grains occurred in this mixed layer. Next to the layer in question, on the surface of the 1-3 cm thick, burnt red, solid layer, some ash-containing spots were observed, which also yielded ceramic and bronze fragments along with calcined bones.

In Section IV, in a depth of 130-150 cm pottery fragments and animal bones were found, on the other hand, in this part of the tumulus the burnt, charcoal-containing layer was observ- 
able on only a relatively small area. Finds occurred more and more seldom. As the works proceeded and the the stones were removed from larger areas the tumulus revealed burnt spots on the surface with small amount of pottery and animal bones. It is problematic that neither photos nor drawings documented these features, moreover there are no hints regarding which sherds come from these parts of the tumulus.

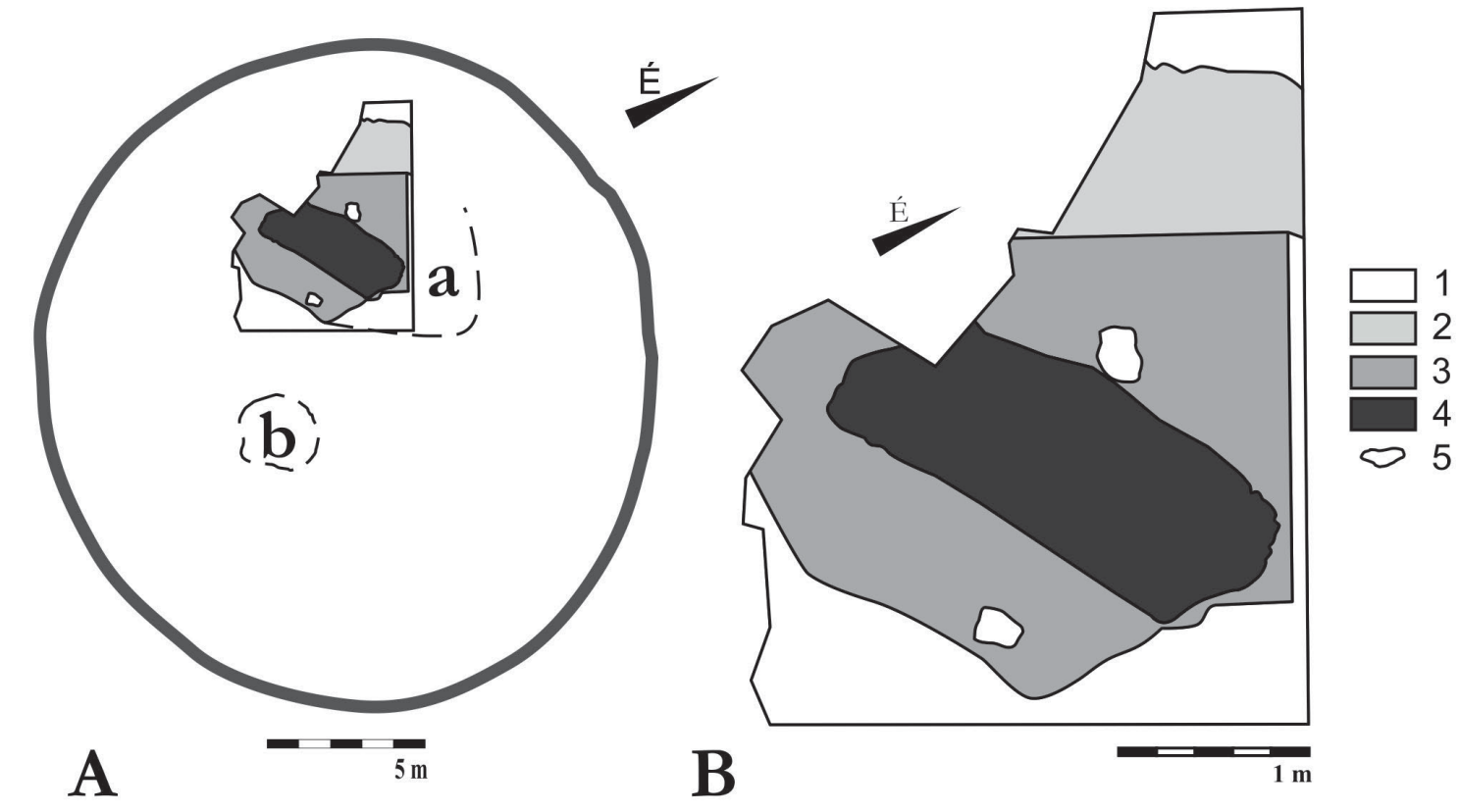

Fig. 5. Tumulus 1. A - The location of Section I in the area of the stone heap. a) - the extension of the burnt layer in Section 2 and 4. b) - sporadic burnt areas with Early Iron Age sherds and animal bones, B - plan of Section I. 1 - brownish-yellow earth, 2 - disturbed part (presumably the dig of Kuzsinszky in 1920), 3 - red burnt layer, 4 - Layer containing ash, calcined bones and pottery sherds, 5 - limestones.

It is also worth mentioning that no circular ditch around the burial mound was found during the excavation. It is noteworthy too, that during the excavation numerous modern graves were found mainly close to the surface of the barrow. The reason for that could be that the cemetery of the village of Tihany is quite near.

\subsection{On the structure of the tumulus}

Set aside that in many cases the exact size of the mound is hardly ascertainable, among the tumuli of the eastern Hallstatt circle - as P. Gleirscher suggests - three categories regarding their size could be defined. ${ }^{16}$ According to the observations and survey of the excavator, the tumulus had a diameter of $28 \mathrm{~m}$, which would let us classify the mound as one of medium size. On the other hand, we learn from the notes of Bálint Kuzsinszky, that the once measurable diameter of the tumuli at Tihany was around 10-15 $\mathrm{m}$ - on which basis the barrow ought to be considered as a tumulus of small dimensions. ${ }^{17}$ In my view, the diameter of the stone packing could be seen as a firm basis to measure the dimensions of the tumulus. According to

16 GLEIRSCHER 2005a, 101.

17 Kuzsinszky 1920, 167. One should bear in mind at this point that Kuzsinszky noted that the tumulus he excavated was the smallest one. 

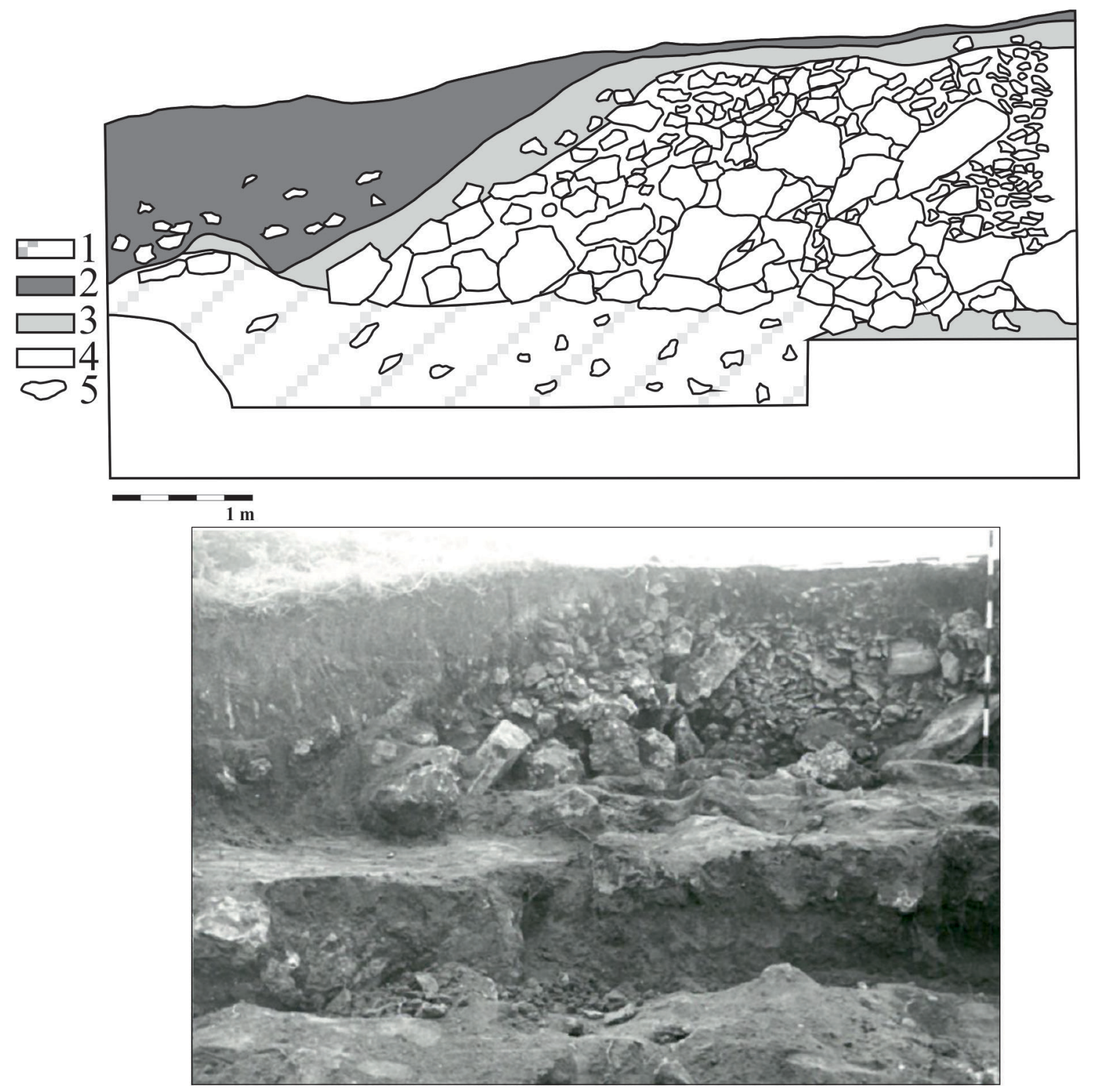

Fig. 6. Profile 3. 1 - Disturbed, mixed earth (?), 2 - Blackish-brown humus, 3 - Brownish-yellow earth, 4 - Yellow sandy clay, 5 - Limestone.

the documentation of the excavation, this diameter is around $21 \mathrm{~m}$. Considering that we might reckon with some amount of earth covering the stone heap, we find it reasonable to classify the tumulus as one of the medium-sized barrows. ${ }^{18}$ On the other hand, we should bear it in mind that these are just estimations, and due mainly to the erosion it is nearly impossible to have clear indications of the original dimensions of the tumuli.

Set aside that we cannot be sure about the exact proportions of the barrow, normally the inner structure of the tumuli could be more or less accurately reconstructed based on the documentation of the excavations. Obviously, this applies mainly to the tumuli that have burial chambers built of stone - often referred to as the graves of the elite of the eastern Hallstatt

18 As Gerhard Tomedi pointed out with the example of the tumulus cemetery of Frög the presence of stone structures do not necesseraly correlate with the dimensions of the tumuli (Tomedi 2002, 101). 

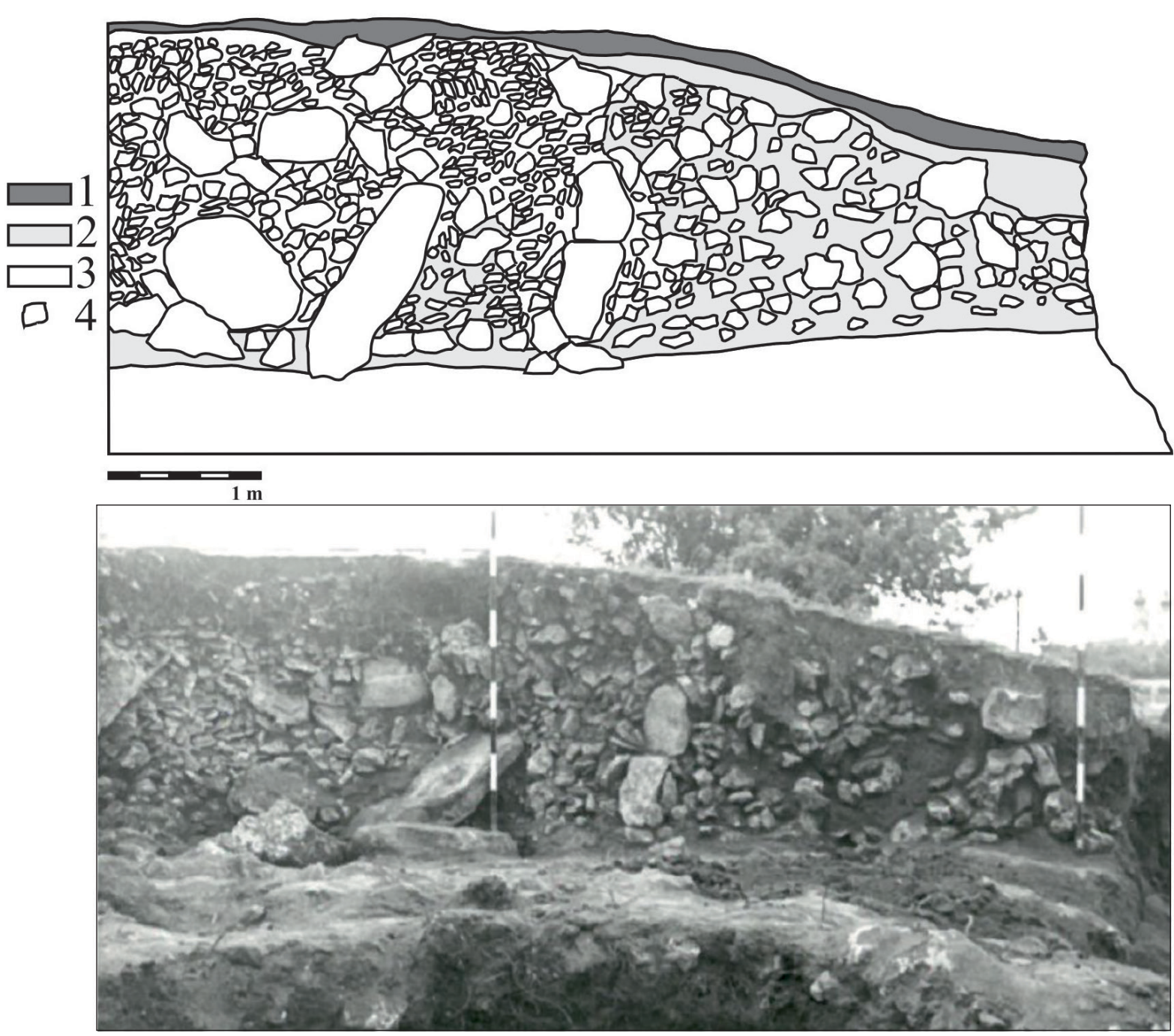

Fig. 7. Profile 4. 1 - Blackish-brown humus, 2 - Brownish-yellow earth, 3 - Yellow sandy clay, 4 Limestone.

circle. ${ }^{19}$ As some relatively questionable ideas state, there might be a correlation between the occurrence of stone-framed burial chambers and the dimensions, ${ }^{20}$ which also points to the necessity of detailed research of the tumuli's inner structure.

Regarding Tumulus I of Tihany, despite the lack of detailed information in the documentation, the followings could be ascertained. During the excavation no structure of any kind alluding to a burial chamber was identified, although at the centre of the stone heap a part with approximately $80 \mathrm{~cm}$ diameter was discovered, which consisted mainly of limestone lumps smaller than the rest of the tumulus' body. Based on the observations documented in the diary of the excavator, this cannot be interpreted as any form of burial chamber. It should be also stated here that most of the finds came from an area situated north of the centre of the tumulus - a burnt, red layer plus a mixed, charcoal- and ash-containing layer, the area of which were both interpreted by Uzsoki as remnants of a funeral-pyre site.

19 Due to this, hitherto the publications dealing with the structural features of the tumuli concentrated chiefly on the ostentatious tombs with burial chamber (DoBIAT 1980, 197; EGG 1996a, 65). It ought to be emphasised that a summary of the characteristic structural elements of the tumuli of the eastern Hallstatt circle is missing yet. Rómer 1878, 115; Pichlerová 1969, 216. 
Among the known tumuli of the eastern Hallstatt circle, barrows consisting chiefly of stone seldom occur (Fig. 10), however, as earlier mentioned there is no published summarising analysis of the inner structure of the tumuli yet. On the other hand, from the area of Transdanubia some instances of such mounds are already known from the literature. At the tumulus cemetery of Zalaszántó several archaeological excavations have been conducted in the $19^{\text {th }}-20^{\text {th }}$ century. These early reports of research state that the body of the barrows consisted mainly of basalt stones, ${ }^{21}$ and that these stone packings were covered with a relatively thin layer of earth. A similar situation was documented by Erzsébet Patek during her excavation at the site at the beginning of the 1970s. The barrow labelled as Tumulus ${ }^{22}$ contained a stone packing of $1.5 \mathrm{~m}$ height, and 26-27 m diameter. However, we should emphasise that this basalt heap, contrarily to the Tumulus I in Tihany, includes a small burial chamber built of slabs. On the other hand, the Tumulus II of the Patek-excavation showed a rather comparable situation with the tumulus in question form Tihany, because the stone packing was built directly above the find-containing layer, and no indication of built structure inside the tumulus was found.

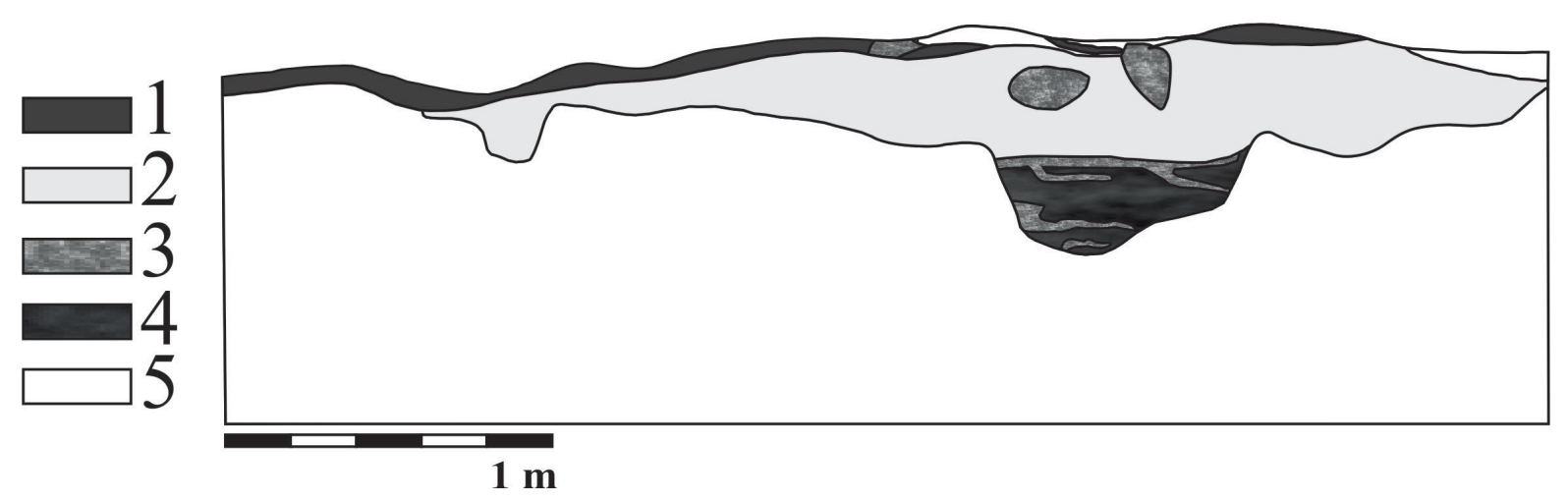

Fig. 8. Profile of the burnt layer. 1 - Red burnt earth, 2 - Loose, brown earth with small amount of findings, 3 - Layer of ash with charcoal, calcined bones and grains, 4 - Solid, ash-containing layer, 5 - Light, yellow clayey sand.

But Erzsébet Patek was not the first who reported about the very fact that the tumuli of Zalaszántó consist mainly of basalt blocks. Towards the end of the $19^{\text {th }}$ century the mounds under the Tátika Hill were disturbed several times. First of the instances that we know of is when Árpád Csák, a local resident, opened the two northernmost tumuli of the Várrét site. ${ }^{23}$ As Vilmos Lipp remembers, these mounds had been erected by heaping up a $2 \mathrm{~m}$ high basalt layer that was subsequently covered with earth. Lipp himself was also interested in the Zalaszántó tumulus cemetery, his workers, however, did not succeed in cutting a way through the stone heap to the assumed burial. ${ }^{24}$ This strongly suggests that the mound of unknown location within the cemetery also contained considerable amount of stone blocks. Thus, we

21 KuZsinszky 1920, 112; DARnay 1899, 277-278. According to the notes of Kuzsinszky at the site Zalaszántó-Várrét the fifth tumulus from south was excavated at the end of the 19th century, thus the inner structure of the barrow became ascertainable. At the same site Árpád Csák examined two tumuli during the 1880s. Based on the available information, the then excavated tumuli consisted fundamentally of basalt blocks the stone heap inside these barrows was $2 \mathrm{~m}$ high.

Lipp 1884, 3. 


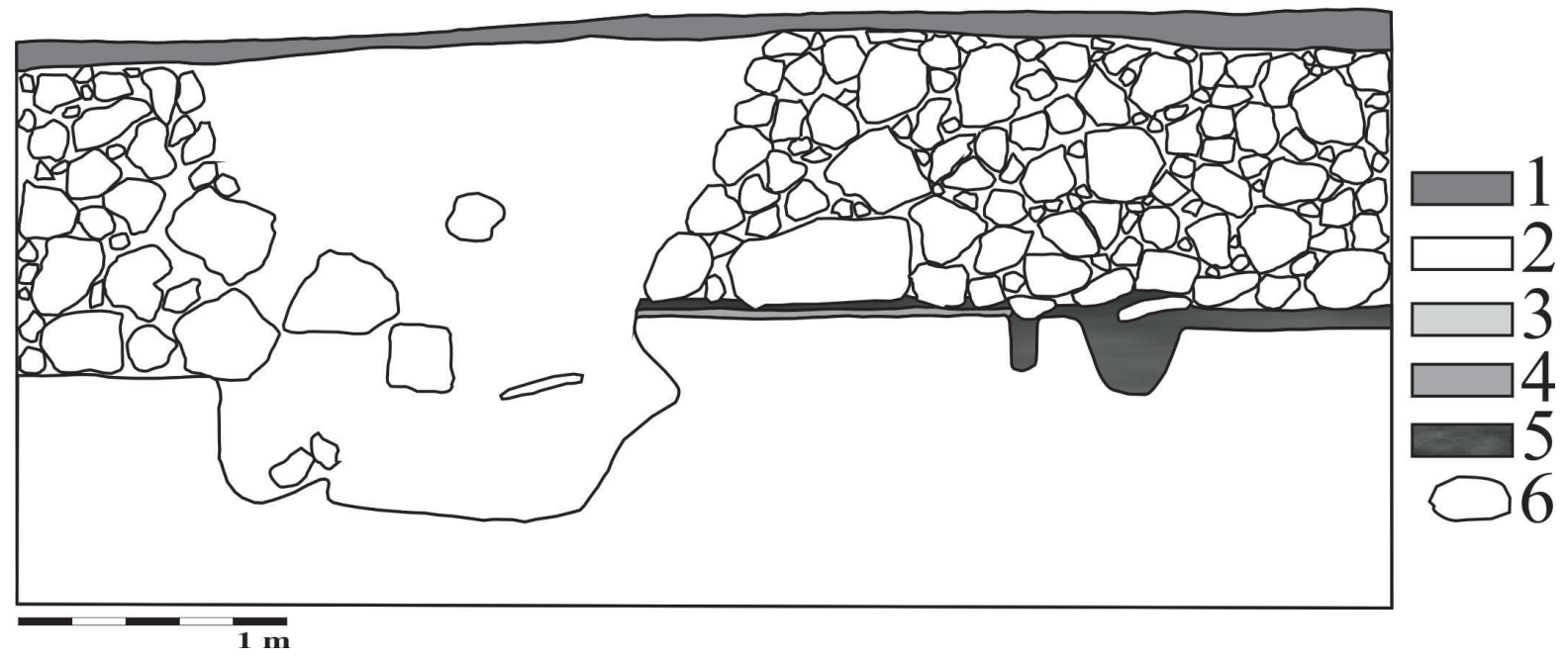

Fig. 9. Profile 2. 1 - Ash and charcoal with a red-burnt layer, 2 - Blackish-brown humus, 3 - Disturbed, mixed earth, 4 - Red-burnt layer with ash, 5 - Yellow clayey sand, 6 - Limestone.

incline to agree with Kálmán Darnay by saying it might be a general phenomenon that the tumuli at Zalaszántó-Várhely were built to some extent of stone. His assumption is also supported by the observation Jenő Lázár made while visiting the tumuli of Zalaszántó. ${ }^{25}$

According to the available information, whoever conducted excavation at the Tihany site, they found stone packings inside the tumuli. As a result, I am convinced to believe that there is a close relationship between the tumulus cemeteries of Zalaszántó and Tihany. (In the following section some additional information supporting the former statement can be read.)

An article written by Iván Ádám in 1880 reports about a noteworthy grave from the Somló Hill. In spite of the fact that the author writes rather briefly about the - from our point of view significant - circumstances of the discovery, he mentions that relatively large blocks of stone scattered in the surroundings of the grave on an area of 0.5 acre. In addition, the article reads that the finds came chiefly from beneath the stones along with a burnt, ash-containing layer. It is tempting to believe that a very similar situation as the known examples from Zalaszántó and Tihany could have been found here ${ }^{26}$ however, we do not possess any further firm indication of such assumption.

Tumulus 115 near Százhalombatta is rather well-known from the literature. According to the available information significant amount of stones were heaped upon the burial chamber. Furthermore, Tumulus 114 and 118 of Százhalombatta also presented stone packings with approximately $10 \mathrm{~m}$ diameter covering their wooden burial chambers. ${ }^{27}$ This structure seems to be also known from Kővágótöttös, from a tumulus-group of 8 barrows under the Late Bronze and Early Iron Age hillfort settlement of Pécs-Jakabhegy. In the late 40's, during the excavation of one of the tumuli a stone covering (d: $10 \mathrm{~m}, \mathrm{~h}: 2 \mathrm{~m})$ was documented, from which the remains of a burial chamber built of wood came to light. ${ }^{28}$

26 Sándor Gallus and Tibor Horváth refer to the described situation as „stone-tumulus” suggesting that the grave could have been covered with a mound consisting mainly of stones. Gallus - HoRvÁth 1939, 129.

27 Holport 1993, 24; Holport 1996, 36.

28 TöRÖк 1950, 5. 
It might be also worth noting that a similar structure have been found in the case of the Late Hallstatt Age princely Tumulus I of Waisenberg..$^{29}$ This remarkable burial mound hid a burial chamber that was covered by a vast stone heap (diameter $20 \mathrm{~m}$, height $4 \mathrm{~m}$ ), upon which a great amount of earth was placed resulting a tumulus with a diameter of $40 \mathrm{~m}$ and a height of $8 \mathrm{~m} .{ }^{30}$

Stone packings covering graves in so-called "flat cemeteries" are also known. In the case of the cemetery near Halimba, Grave I came to light after the removal of a stone heap with a diameter of $2.3 \mathrm{~m}$. As a result the excavator does not rule out the possibility that the cemetery included tumuli too. ${ }^{31}$ In addition, several graves of the cemetery were enclosed or covered by stone blocks to some extent. ${ }^{32}$ On the other hand, we do not know whether any characteristic structure could have been identified.

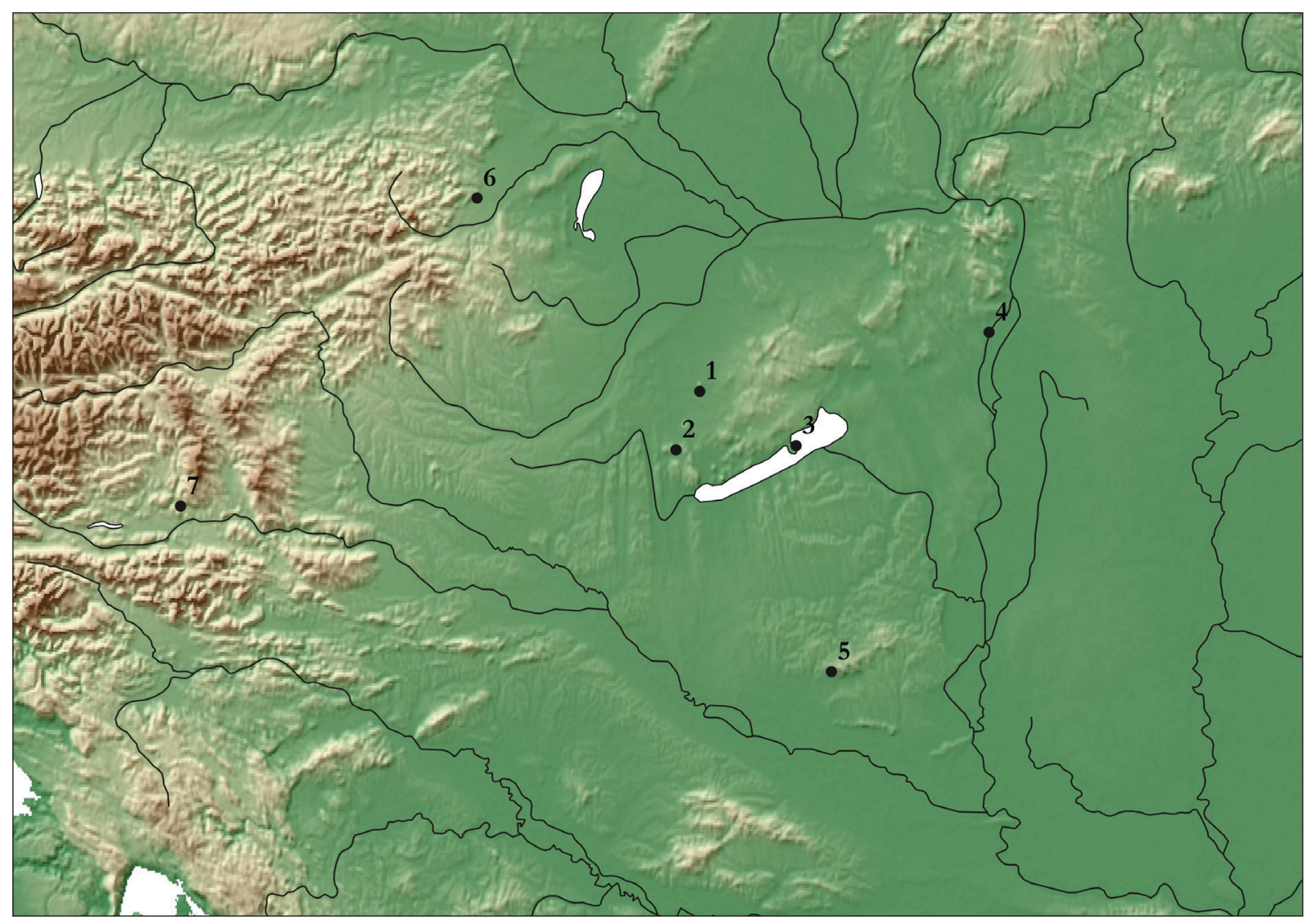

Fig 10. Map showing the location of tumuli comprising great quantity of stone. 1 - Somlóvásárhely, 2 Zalaszántó-Várrét, 3 - Tihany, 4 - Százhalombatta, 5 - Pécs-Jakabhegy, 6 - Bad Fischau, 7 - Waisenberg.

\subsubsection{Pyre}

In the followings we should discuss the excavator's interpretation of an interesting feature found under the stone packing. According to Uzsoki, they found the remains of what he thinks to be the funeral pyre. According to the literature it is not an uncommon occurence in the case of the tumuli of the eastern Hallstatt zone. However, it is significant to distinguish 
between at least two different types of pyre debris based on whether they are in primary or secondary position inside the mound. Our question here is whether we can reckon with an actual funeral pyre under Tumulus I of Tihany.

Both types seem to be common phenomena of the eastern Hallstatt zone. Let us firstly deal with the instances in the vicinity of Tihany. Unfortunately, the publication of the tumulus near Mesteri was not written by the excavator, but Jenő Lázár who was present at some points of the works. He claims that under the tumulus, next to the remarkable wood-stone burial chamber the remains of the funeral pyre might have been discovered. ${ }^{33}$ According to Lázár it was a layer of ash and charcoal $30 \mathrm{~cm}$ thick and $5 \mathrm{~m}$ in diameter, and it also contained considerable amount of burnt metal objects, and even pottery fragments. ${ }^{34}$ Lázár informs us about a similar situation regarding Tumulus I near Csönge. Based on his description, north of the mound's centre a layer of charcoal was found that only yielded pottery fragments. ${ }^{35}$

Unfortunately, we do not know very much about the features of the first Somlóvásárhely tumulus, however, both Erzsébet Patek ${ }^{36}$ and Markus Egg, ${ }^{37}$ based on Rhé's brief description of the situation, ${ }^{38}$ give credit to the assumption that Rhe discovered the actual funeral pyre under the mound.

The Zalaszántó-Várrét tumulus group has already been highlighted because of the characteristic inner structure of the mounds comparable with the Tihany mound, but I would like to emphasise their significance once again. The reason is that the second barrow excavated by Erzsébet Patek showed a situation that reminds us of the feature that Uzsoki suggested to be a pyre, namely a 5-15 cm thick layer containing a large quantity of charcoal. ${ }^{39} \mathrm{I}$ have to emphasise, however, that the available literature on both tumuli of Zalaszántó is yet rather scarce, the doubts about the interpretation above cannot be dispelled.

The situation described by András Figler based on Arnold Börzsönyi's observations about the first tumulus near Győrújbarát is interpreted as it might have been the remains of the funeral pyre, however, Börzsönyi's reports, in which he writes about a layer of ash containing cremated human remains and pottery fragments, raise doubts about Figler's thoughts on the matter, since the report does not specify whether the remains are in a primary or a secondary position, neither specifies the extension and quantity of the remains.

The best-known instance of remains of a funeral pyre in primary position was discovered under the famous tumulus near Süttő. The excavator, Éva V. Vadász gives us a detailed description about the feature discovered under the rammed floor of the burial chamber. Similar to the Tihany tumulus, in the case of Süttő the remains of the funeral pyre laid on a burnt layer, which might be seen as the main evidence that the mound was built where the cremation of the deceased had taken place. However, this burnth earth layer seems to be much bigger than the similar feature discovered in the Tihany tumulus, since V. Vadász writes about an area of 
16 by 9.5 meters. ${ }^{40}$ The amount of the anthropological and archaeozoological remains $(17 \mathrm{~kg})$ heaped next to the burial chamber's wall, presumably the remains of the cremation and pyre goods, ${ }^{41}$ also suggests that this pyre envisaged in a much larger scale than in the case of the Tihany tumulus.

Let us now briefly write about the tumuli, in which the pyre remains were in secondary position, suggesting that the cremation had taken place somewhere else. Tibor Kemenczei gives us a perfect example of this. With reference to the tumuli near Nagyberki, he emphasised that none of the excavated mounds was built on the spot of the cremation of the deceased, the remains of the pyre, found either in the burial chamber or the grave pit, were in secondary position in the grave pits. ${ }^{42}$ During the excavation of the first tumulus' chamber, Kemenczei found the pyre remains and ash on the paved floor, and no traces of burnth layer were found under them. ${ }^{43}$ Another example of pyre remains in secondary position are the tumuli excavated near Vaskeresztes. Mária Fekete reports about remains of charcoal and ash in the corner of the first tumulus' chamber, and similar material covered a small area of the chamber and the dromos in the second mound. ${ }^{44}$ Both of the examples of Szalcska and Vaskeresztes suggest that the spot of the cremation was somewhere else. Similar situation is known in the case of two of the tumuli near Nové Košariska. ${ }^{45}$

Based on the aforementioned examples, it seems likely that the Tihany tumulus was in fact built above the very place of the cremation. ${ }^{46}$ So, to some extent, Uzsoki is right in interpreting the burnt surface and the charcoal-containing layer. Truth to be told, however, in his perception, he did not find a grave under the mound but the site of the cremation belonging perhaps to the cemetery used by the inhabitants of Ovár. ${ }^{47}$ Despite this, he confusingly uses the term 'Hügelgrab', ${ }^{48}$ suggesting that the mound indeed covered a burial. Similarly to Uzsoki, in the case of Tumulus 75 at Százhalombatta Ágnes Holport identifies a funeral pyre under a mound, but no grave, hence the interpretation that it could have been a central location within the cemetery, where the cremation used to take place. ${ }^{49}$ This mound showed features that could be easily compared to the Tihany tumulus. For instance, no sign of any built structure was to be identified, the remains of the pyre were a burnt surface, and a great amount of charcoal and calcined human bones were scattered on the surface. Holport's interpretation is also supported by the analysis of the human remains, according to which the bone fragments are the remains of several people..$^{50}$ Unfortunately, the anthropological finds from the Tihany tumulus have not been analysed yet, thus I am not able to rely on them while evaluating the problem of Uzsoki's interpretation. On the other hand, both of the mentioned tumuli yielded

40 VADÁsZ 1983, 35.

41 VADÁsz 1983, 35.

42 KemenCZei 1975, 165.

43 Kemenczei 1974, 4.

44 FEKETE 1985, 41, 53.

45 Müller 2012a, Tab, 2. tumulus 2: Pichlerová 1969, 32-33; tumulus 6: ibid. 89. The latter mound covered multiple burials: ibid. 90-95.

46 The extensive burnt surface, the layer containing cremated remains, ash and charcoal and the small pit filled by the pyre debris seem to clearly indicate that in the case of the Tihany tumulus, the mound was erected above a funeral pyre. McKinley 1997, 134; Fontijn ET AL. 2013, 131; McKinley 2013, 152

47 Uzsoki 1986, 248.

48 Uzsoki 1986, 248-249.

49 Holport 1985, 27; Holport 1993, 24.

50 HolPORT 1985, 27. 


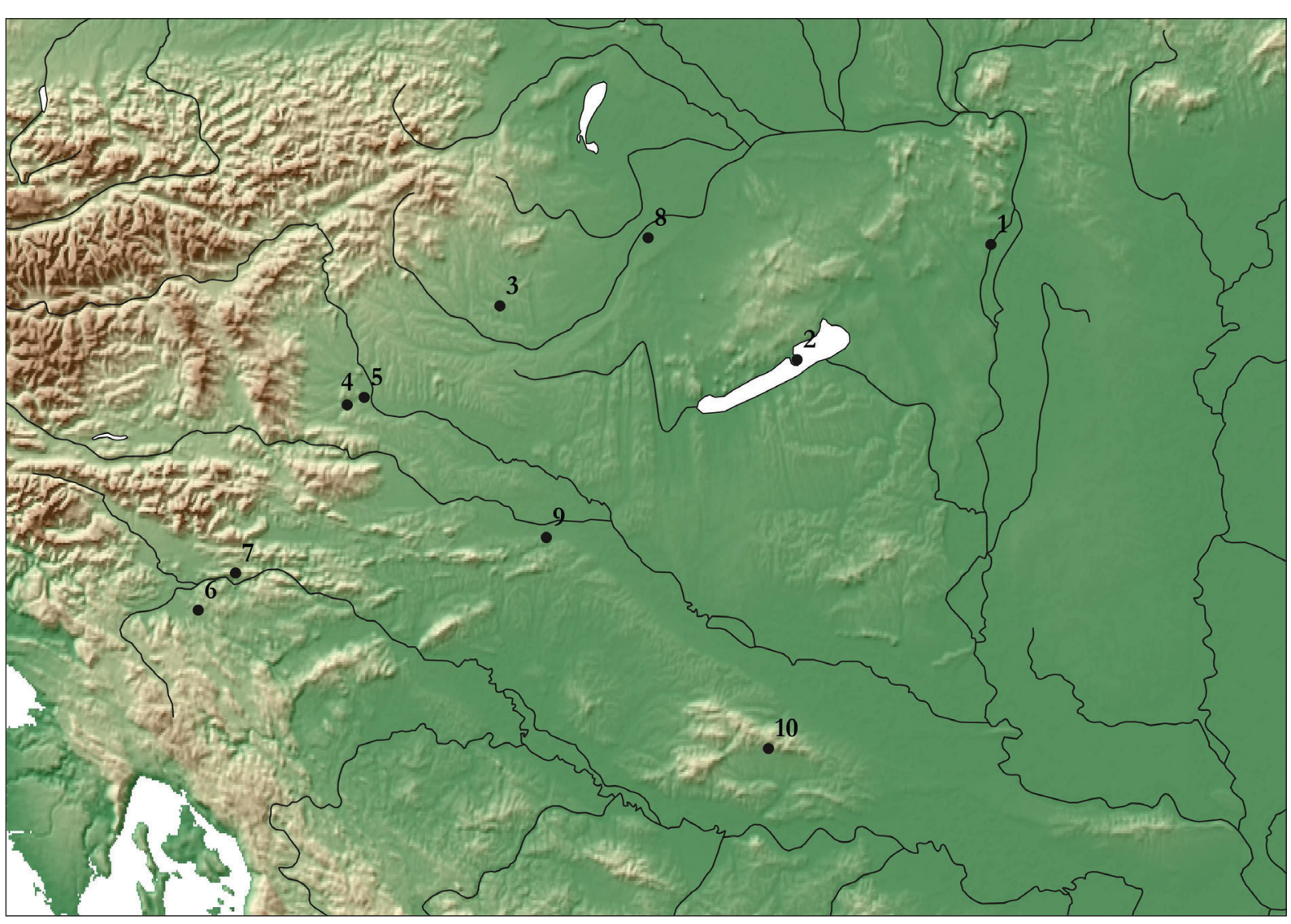

Fig 11. Map showing the distribution of the so-called Henkelfußtassen. 1 - Százhalombatta, 2 - Tihany, 3 - Vaskeresztes, 4 - Kleinklein, 5 - Leibnitz-Altenmarkt, 6 - Magdalenska gora, 7 - Vače, 8 - Csönge, 9 - Martijanec, 10 - Kaptol.

ceramic finds, consisting chiefly of strongly fragmented vessels that cannot be reconstructed. ${ }^{51}$ According to the authors, this might also support the mentioned interpretation. ${ }^{52}$ In general, central cremation places of cemeteries of the Hallstatt Age are scantly known. An example could be the so-called Verbrennungsplatz der Höchsunterwaldgruppe of the Sulmtal cemetery.

Of course, there are several instances of tumuli from other regions, in which the excavators incline to identify the remains of the funeral pyre in primary position. Firstly, in the case of the tumulus cemetery at Bad Fischau we are informed that under some of the mound, an extensive burnt layer was found under a heap of stone blocks, a feature that is to some extent comparable with the inner structure of the Tihany tumulus..$^{53}$ In addition, burnt surfaces under several tumuli in Slovenian Styria were to be found. Biba Teržan believes these indicate that the cremation took place at the place of the mound. ${ }^{54}$ Furthermore, the preliminary reports about the hitherto unpublished tumuli near Goričan in the Mur valley, in Croatia also suggest that these mounds were also erected above the remains of the burnt down pyre. ${ }^{55}$

51 Holport 1985, 26. Interestingly, during the excavations of the tumulus cemetery between Százhalombatta and Érd in 1847, the found ceramic assemblage was also in very fragmentary state. LUCZENBACHER 1847, $288-289$.

52 Uzsoki 1986, 248-249; Holport 1985, 27; Holport 1993, 24.

53 Bad Fischau 1: Szombathy 1924, 166; tumulus 2: ibid. 168; tumulus 3: ibid. 172; tumulus 4: ibid. 174; tumulus 5: ibid. 177; tumulus 7: ibid. 181; tumulus 8: ibid. 182-183; tumulus 9: ibid. 183; tumulus 10: ibid. 184-185; tumulus 11: ibid. 190-191; tumulus 12: ibid. 191; tumulus 14: ibid. 193.

54 TERŽAN 1990, 57.

55 ŠIMEK 2004, 107. 


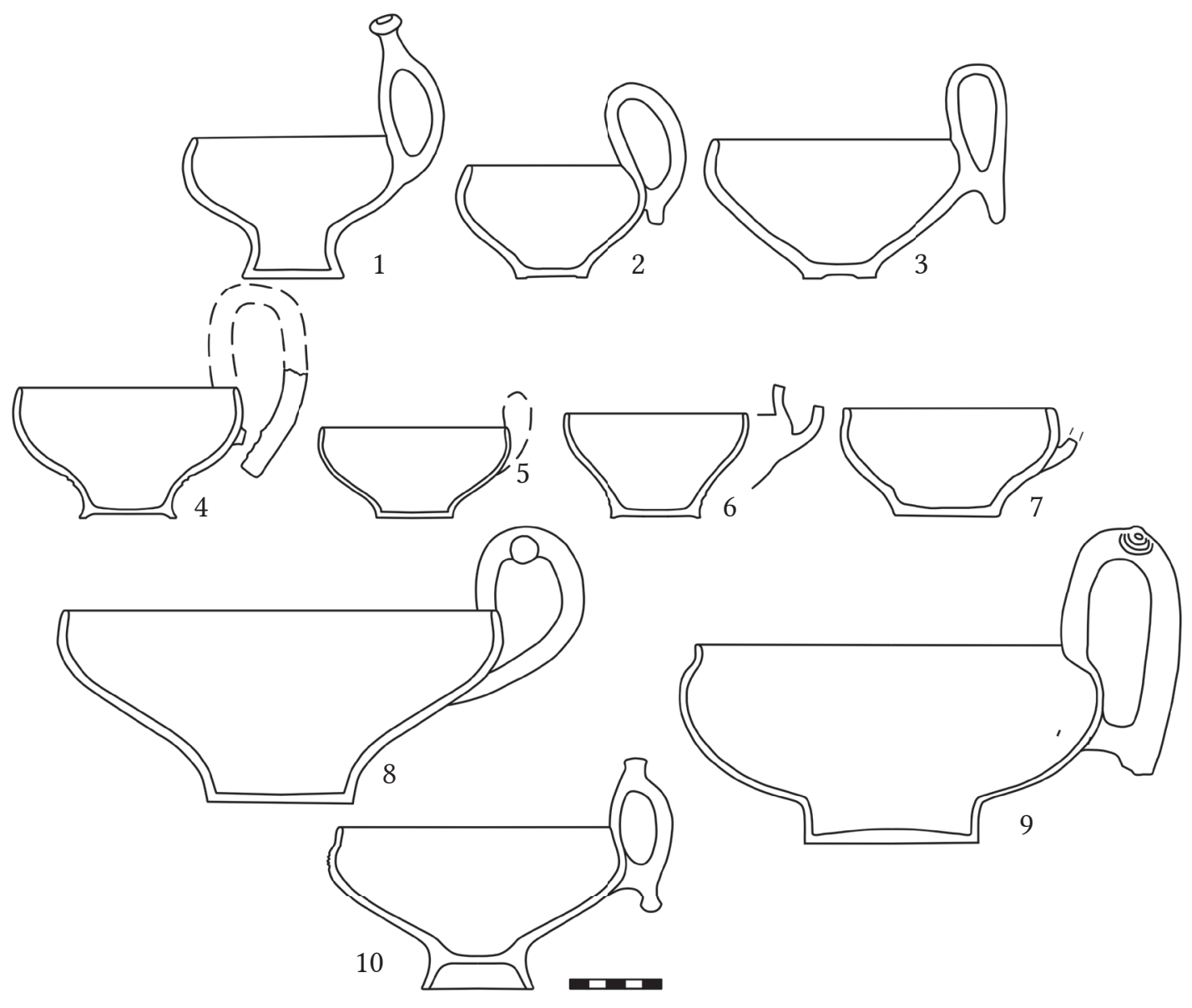

Fig 12. Henkelfußtassen from the eastern Hallstatt circle. 1 - Kröllkogel (EGG - Kramer 2013, Taf. 72.1-2), 2 - Kröllkogel (EGG - Kramer 2013, Taf. 72.3), 3 - Leibnitz-Altenmarkt 2/92 (HAMPel 2005, Taf. 6.27), 4 - Tihany Tumulus I, 5. Vaskeresztes Tumulus II (Fekete 1985, Abb. 20.1), 6 - Vaskeresztes Tumulus II (Fenete 1985, Abb. 20.3,6), 7 - Szombathely-Reiszig erdő alatt (ILoN 2004, Tab. 62,7), 8 - Vaskeresztes Tumulus II (Fekete 1985, Abb. 17.2), 9 - Százhalombatta Tumulus 114 (Holport 1985, Fig. 23.2), 10 - Magdalenska gora-Preloge Tumulus 13, Grave 138 (Hvala ET AL. 2004, Taf. 112.C)

If we take the Kleinklein cemetery into consideration, some examples of pyres under the tumuli could also be taken into account. For instance, similarly to the Sütto mound, in the so-called Tschoneggerfranzltumulus 2 the place of the cremation was identified next to the chamber. ${ }^{56}$ According to Claus Dobiat's classification, a group of the so-called Brandflächengräber could be circumscribed. ${ }^{57}$ This burial type appears in the younger phases of the cemetery. ${ }^{58}$ One of the most characteristic features of these graves is a more or less extensive burnt surface. Some of the examples listed by the author, however, cannot be seen as the place of the cremation, since a pyre that should support the deceased and the pyre goods as well as it should provide sufficient heat could not have been as small as an area of $30 \times 70$ $\mathrm{cm}^{.59}$ In this regard I have to mention that the burnt surface found in the Tihany tumulus satisfies this condition, hence it could be seen as the actual place of the burnt down pyre. 


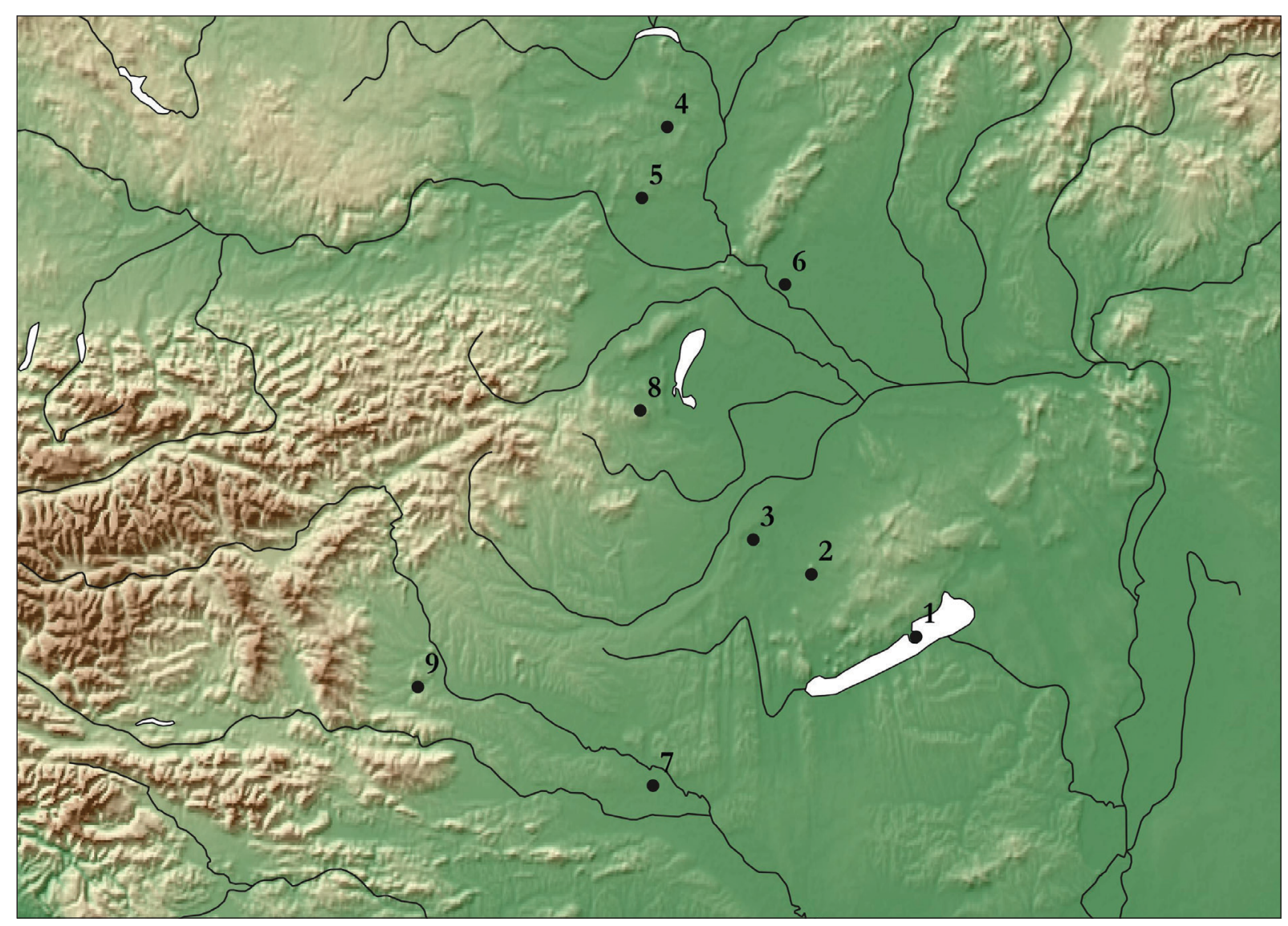

Fig. 13. Distribution of ceramic bird figurines on vessels. 1 - Tihany, 2 - Somlóvásárhely, 3 - Mesteri, 4 - Bullendorf, 5 - Pillischdorf, 6 - Nové Kosariská, 7 - Dvorišče, 8 - Sopron-Várhely, 9 - Kleinklein.

An interesting development is that in the early 1990's a new tumulus was excavated in the Kleinklein cemetery that had not been known earlier. The Wiesenkaisertumulus 4 will be mentioned later too, here I would like to write only about the form of its burial. It is an exceptional example, because of the fact that contrary to the majority of the so far published tumuli, it was excavated quite recently with remarkable care. ${ }^{60}$ Although the tumulus was nearly entirely levelled, the main features seemed to be observable. ${ }^{61}$ As a result, already Gerhard Tomedi took the view, that the strongly burnt layer of earth under the tumulus represents the place of the cremation. ${ }^{62}$ Later, Silvia Hack agreed with this, and argued that the mound in fact covered the pyre remains in primary position. ${ }^{63}$ Although the burial seems to resemble the main characteristics of the so-called Brandflächengräber, neither Tomedi nor Hack uses the term. According to them, the strongly burnt layer on which ceramic fragments exposed to high temperature and some human and botanical remains scattered ${ }^{64}$ suggests that a Bustumgrab had been discovered. ${ }^{65}$ In the case of a more recently excavated tumulus in SouthEast Styria, Andreas Lippert also assumes that the burial could be seen as a Bustumgrab,

60 TOMEDI 1992; HACK 2002.

61 Tomedi 1992, 212; HACK 2002, 99-104.

62 TOMEDI 1992, 212.

63 НАCк 2002, 104-105.

64 ToMEdi 1992, 212; HACK 2002, 99-102.

65 Tomedi 1992, 212; НАCK 2002, 104. 

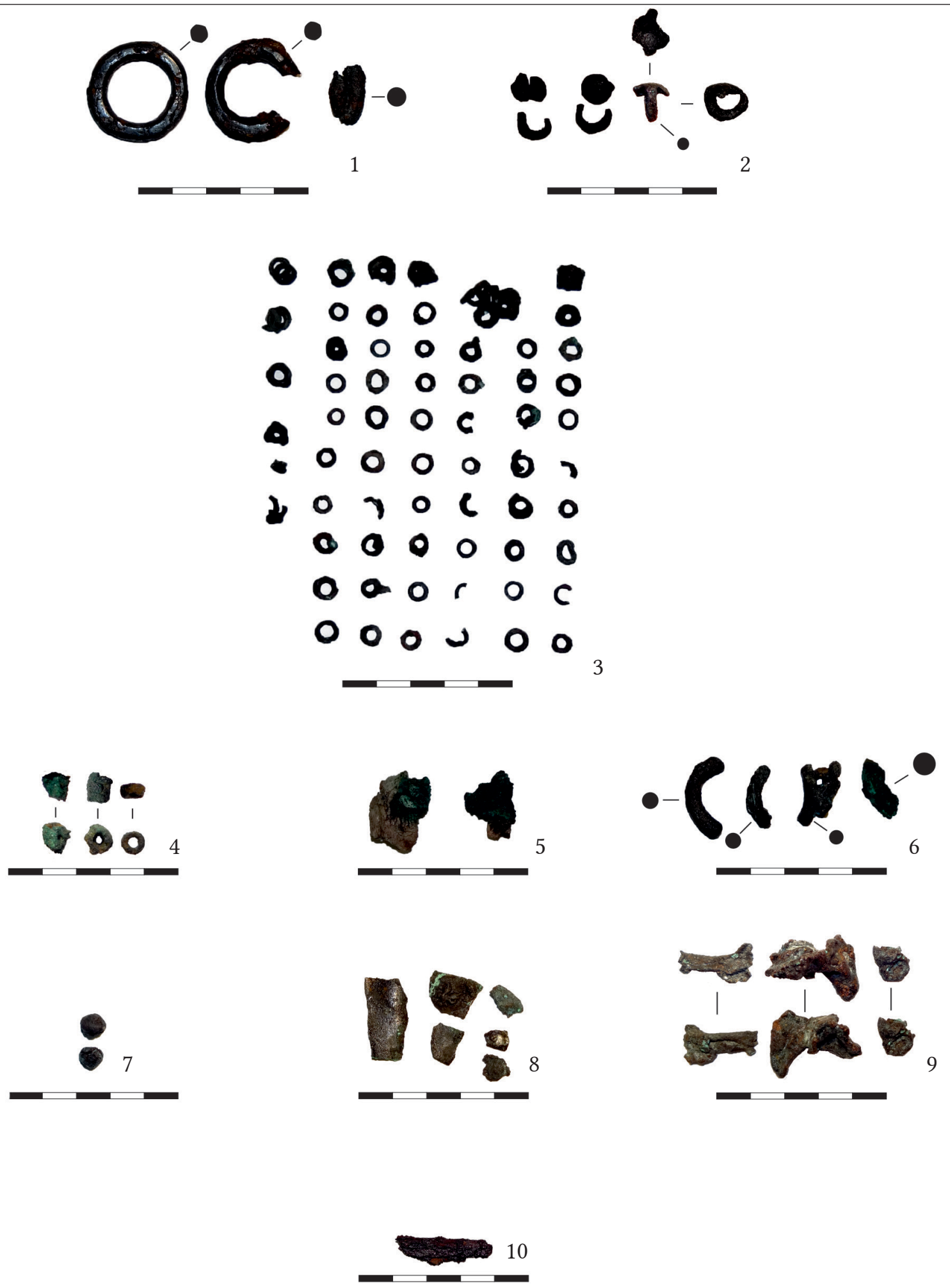

Fig 14. Metal finds of Tumulus 1.

based on the hard, strongly burnt layer of earth, ${ }^{66}$ a feature that had been highlighted in the case of the Wiesenkaisertumulus 4, too. In fact, by definition, every tumulus could be a Bustumgrab where the grave is located at the place of the cremation. ${ }^{67}$ Yet, it should be kept

66 LIPPERT 2008, 83.

67 Sørensen - Rebay 2005, 154. 
in mind that in this case the human remains were found in a bronze vessel, i.e. an urn, which seems to suggest a dissimilar situation compared to the Tihany tumulus. I have to emphasise that based on the available information here the human remains scattered over a relatively large area shows no sign of previous intention of collecting them.

As a conclusion, it cannot be ruled out that under the Tihany tumulus in fact the actual place of the cremation, the pyre remains in primary position have been found. However, I would not agree with A. Uzsoki, that there was no grave. Based on the examples of the so-called Brandflächen- and Bustumgräber in Styria and Northern Croatia, it is conceivable that under the Tihany mound a similar burial form was found. Truth to be told, based on Uzsoki's notes a surface of $2.5 \times 3 \mathrm{~m}$ area was found under the stone heap, south of the aforementioned hard, red burnt layer, on which several sporadic burnt remains scattered along with sherds and animal bones. Unfortunately, there is no photo nor drawing of this feature, that could help us ascertain whether it was a part of the burial, and how it should be interpreted. Frankly, based on the burial forms featuring remains of the pyre, it is not unusual to find various burnt surfaces under a tumulus, and this does not necessarily suggest that the mound covered multiple burials. ${ }^{68}$

\subsection{Discussion of the ceramic assemblage from the tumulus}

\subsubsection{Comments on the inventory and the restoration of the ceramic assemblage}

The finds of the tumulus are stored at the Laczkó Dezső Museum of Veszprém under the inventory numbers $72.10 .13-81$. We must emphasise that this system needs a revision, especially when the identification of the adjoining fragments was not supported by the motives of the decoration. This is most obviously showed by the group of fragments labelled as 72.10.67-71. that contained several adjoining sherds of different vessels already distinguished and labelled with an own inventory number. As a result, we had the opportunity to entirely reconstruct the profile of some vessels, for instance the V03 bowl and the situla-shaped vessel (V06). Thus we are convinced that in this case a new system of the inventory is necessary. The easily distinguishable vessels, considering their decoration, material, surface treatment and shape were assigned to a label (V00), then the fragments that might have belonged to the same vessel were also enumerated, even though the fragments could not have been joined together (V00F00 marking the possible fragments of a (V00) vessel) ${ }^{69}$ Specimens marked with a label like this $\mathrm{IF} 00$ can be identified as fragments of a lid. The sherds of rims ( $\mathrm{rF} 00)$ and bottoms (bF00) have been labelled similarly. The same labels identify the potteries on the plates and in the catalogue, too.

\subsubsection{The technological characteristics of the ceramics}

The potteries are all hand-made without exception. As for their material, it is chiefly fine-levigated and fine-tempered clay. Grits seldom occur in the matrix of the sherds. Polishing and graphite-coating can frequently be observed as surface treatment, suggesting also that the vessels were mainly of fine quality. In some cases graphite painting was used for the decoration of the interior and less frequently the exterior. Interestingly, there is only one vessel that can be categorised as coarse ware (V07). 


\subsubsection{Vessels}

\subsubsection{Bowls with handle}

Considering their shape and decoration there are three vessels of the type in question among the grave goods of the tumulus (labelled as V01, V02 and V03), however, the V03 specimen should be considered as a distinguishable variant of the type. Neither of them could be entirely reconstructed. We were able to find traces of secondary burning mainly in the case of the V02 and V03 bowls; the adjoining fragments have different colour, which may suggest that the vessels were on the funeral pyre, and they were broken at some point of the cremation.

To begin with, we discuss the V01 and V02 vessels that bear fundamentally similar shape and decoration, and both of them were made with the same surface treatment (Fig. 19). During the excavation of Tumulus I near Somlóvásárhely fragmented specimens of this type have been found. On the other hand, regarding their decoration they represent dissimilar vessel to the two specimens in question. ${ }^{70}$ These fragments presumably belonged to bowls similar to the specimen found in one of the tumuli near Vaszar by Gyula Rhé. ${ }^{11}$ Characteristic common features of these are the followings: they have funnel-like rims, conical necks, and their bulging middle part is decorated by densely spaced vertical cannelures. On their handles we can see three vertical ribs as decoration, a feature that also occurs in the case of the specimens found in Tumulus I of Tihany. The handled bowls from Somlóvásárhely and Vaszar remind us of the specimens of the type found in the tumuli of Pécs-Jakabhegy. ${ }^{72}$

The characteristic vertical channelled decoration appears on a specimen found in Tumulus $1 / 57$ of Hurbanovo ${ }^{73}$ and on the two - almost identical - bowls belonging to the type in question from the tumulus near Mesteri. ${ }^{74}$ However their shape is more similar to the specimens found in the Tihany barrow, as they have slightly everted - instead of funnel-like - rims, and conical necks. In addition, analogous vessels are known from the funeral mound near Kismező, ${ }^{75}$ from the tumuli at Fehérvárcsurgó-Eresztvényi-erdő ${ }^{76}$ and a significantly fragmented specimen came to light from Tumulus 13 near Vaszar. ${ }^{77}$ Tumulus II of the cemetery near Vaszar excavated by Gyula Rhé yielded according to Attila Horváth a bowl belonging to the type in question that bears elements of decoration - knobs and the oblique lined cannelures - along with graphite painted, " $\Lambda$ "-shaped ornaments on the neck dissimilar to the V01, V02 specimens. An exceptionally richly decorated specimen was discovered in Tumulus 3 of the Vaszar-Pörösrét cemetery, ${ }^{78}$ which represents the bowl type under discussion, although its proportions are slightly different from the formerly mentioned examples.

HoRvÁTH 1969, 111.

HoRvÁth 1969, 119.

MARÁz 1996, Abb. 2, 4; Abb. 3. 7.

PAUlí́ 1958, 362, Tab. 3.4.

LÁzÁr 1951, 36, Tab. 26. Fig. 1.a,c.

LÁzÁr, 1951, 40, Tab. 30. Fig. 1; Fig. 2.c.

The detailed publication of the tumuli near Fehérvárcsurgó is not yet accomplished, however, the majority of the grave goods is exhibited in the Szent István Király Museum of Székesfehérvár. PETres - JunGBERT 1997.

Mithay 1980, 64; Patek 1993, 107. Abb. 86.10.

PAtek 1993, Abb. 77. 17. 
Considering that the V02 bowl has a strongly bulging shape, we believe its closest analogies - regarding shape and decoration - could be the specimens found in the tumuli near Csönge ${ }^{79}$ and Vaszar. ${ }^{80}$ Similar bulging shape and comparable decoration can be observed in the case of a bowl found in the mound of Sütto" ${ }^{81}$ This characteristic, strongly bulging shape leads us to mention a bowl found in Tumulus II near Réca which is significantly comparable with the V02 specimen, however instead of "V"-lined cannelures it possesses painted "V"-shaped ornaments on its shoulder. ${ }^{82}$

We might also briefly touch upon the handled bowls known from the tumulus cemeteries of the Kalenderberg group. Normally these specimens have handles raised above the rim as we see - for instance - in the case of Sopron-Burgstall, ${ }^{83}$ Loretto $^{84}$ Bad-Fischau $^{85}$ and Statzendorf. ${ }^{86}$ It is also worth mentioning that among the funerary equipments of the graves in the North-Eastern pre-Alpine region, this vessel type does not appear as frequently as it does in the case of Transdanubia. ${ }^{87}$

Furthermore, we should take into consideration the bowls of the type in question found in graves of the so-called "flat cemeteries". We find such handled bowls among the - to some extent fragmentary - vessel set from the Halimba-Cseres cemetery, ${ }^{88}$ however they are more or less dissimilar to the specimens of the Tihany barrow considering their shape and decoration. Other examples are the cemeteries Tatabánya-Dózsakert, ${ }^{89}$ Tatabánya-Alsó vasútállomás, ${ }^{90}$ and Nagydém-Középrépáspuszta. ${ }^{91}$ Two similar undecorated handled bowls - potentially belonging to the type under discussion - came to light from the site Tokodaltáró-Erzsébet akna. ${ }^{92}$ Further examples can be mentioned in the case of the cemeteries of Nové Zámky ${ }^{93}$ and Modrany, ${ }^{94}$ which also bear the "V"-shaped cannelures on the shoulder as well as the knobs as decoration. A bowl belonging to one of the graves of the cemetery near Bajč decorated only with knobs could be also classified among the type in question.

It has been mentioned earlier that among the funerary equipment of the tumulus only two specimens of the variant - represented by the V01 and V02 specimens - could be found, although we cannot rule out the possibility that a third one was also part of the assemblage.

80 Tumulus 2 of the cemetery near Vaszar. Mithay 1980, Fig 6. 3; PATEK 1993, Abb. 77. 14.

81 VADÁsz 1983, Fig. 18.

82 ChropovsKÝ 1955, 771.

83 Eibner-Persy 1980, 44; Patek 1993, Abb. 36.

84 NeBELSick 1997a, Abb. 11.

85 Klemm 1996, Taf. 4.3,2.

86 ReBAy 2006, 101.

87 VADÁsz 1983, 46.

88 Grave 7: Lengyel 1959, 159, Tab. 34. 7; Grave 10: ibid. 160, Tab. 35. 8; Grave 12: ibid. 161, Tab. 36. 4; Grave 14: ibid. 161, Tab. 37. 8; Grave 17: ibid. 161, Tab. 39. 6; Grave 21: ibid. 161, Tab. 42. 2a-c; Grave 36: ibid. 163, Tab. 48. 11; PAtek 1993, Abb. 73. 8 - the accuracy of this depiction is to some extent questionable.

89 There is a great variability among the vessels of the type under discussion from this cemetery regarding their shape and decoration, also noteworthy that they are scarcely analogous to the bowls from Tihany. VADÁsz 1986a, Abb. 4, Abb. 5.

90 Groma 2015, Abb. 7.2.

91 Grave 3: Nagy 1939, Tab. 1. 12; Grave 5: ibid. Tab. 2. 7; Grave 16: ibid. Tab. 4. 11; Grave 19: ibid. Tab. 5. 9; Grave 1B: ILON 1992, Fig. 7. 4.

92 PAтек 1982/83, Taf. 18. 15, 17.

93 Stegmann-Rajtár 2009, Tab. 4. 6; Tab. 5. 2; Tab. 9. 6; Tab. 15. 3; Tab. 18. 9.

94 DušEk 1976, Abb. 3. 4. 
Some of the vessel fragments labelled as V01F01 might have been pieces of the V01 bowl considering their shape, surface treatment and decoration, however, based on the spacing of the channelled ornamentation we estimate that the V01F01 shreds could have belonged to a different vessel yet very similar to the V01 specimen, patently not the V02 bowl. The fragments belonging to the vessel distinguished as V08 resemble to some extent the specimens discussed above, however, they bear a different feature regarding its slightly profiled rim-neck section (Fig. 23). Considering this, the bowls from Tumulus I at Csönge ${ }^{95}$ and Süttő ${ }^{96}$ could be mentioned as analogous vessels. To sum up, we think that although the above enumerated specimens bear certain dissimilar features - regarding either shape or decoration -, their fundamental functional attributes could have been analogous.

On the other hand, V03 represents an utterly different variant among the handled bowls considering its proportions ${ }^{97}$ and the shaping of its handle. However, at this point we should emphasise that currently it is somewhat hypothetical whether the fragment V03F02 could be considered as the handle of the V03 vessel, since it cannot be adjoined directly to the rest of the vessel ${ }^{98}$ (Fig. 20). Thus when seeking for parallels of this bowl we cannot take the characteristic handle fragment into consideration.

Distinctive features of the vessel are the sharply profiled section of the bulge and the shoulder, and the wide foot of the vessel, based on which analogous handled bowls could be enumerated, mainly from the regions of Styria and Slovenia. For instance a bowl bearing some of the characteristic features seen on the V03 vessel came to light from a burial context at Kasmatec pri Preski. ${ }^{99}$ A noteworthy specimen found at Libna seems to support our assumption that the V03 vessel had a handle raised high above the rim. ${ }^{100}$ On the other hand, the best analogy of the vessel under discussion comes from the Kleinklein cemetery, from Tumulus 34 of the Grellwald group ${ }^{101}$ however, it should be pointed out that it is considerably more decorated. Ch. Dobiat classified this specimen among the so-called 'profilierte Henkelschalen'. According to the literature, this bowl type seems to be frequently shaped with an ansa lunata/ansa cornuata handle, which also makes it conceivable that the fragment V03F02 - as earlier mentioned - could have belonged to the vessel.

Another significant feature about the bowl under discussion is its decoration recognisable on the vessel's bulge and shoulder, consisting of channelled lines forming so-called 'Negativrauten' ornaments. ${ }^{102}$ According to the collection and classification of Hallstatt Age ceramic ornamentation made by Ursula Brosseder, this specific motive is rare and its easternmost occurrence can be found among the vessels known from the tumuli of Sopron-Burgstall. ${ }^{103}$ However, we would like to note that in the case of bowls, this motive mainly occurs in the

99 Dular 1982, Tab. 22. 198.

100 Dular 1982, Tab. 22. 201.

101 Dobiat 1980, Taf. 74. 1.

102 BRosseder 2004, 182.

103 For instance Eibner-Persy 1980, Taf. 93. 7; Brosseder 2004, Abb. 122. 
Northern pre-Alpine regions. Anyway, in our view the V03 bowl is a peculiar vessel considering the handled bowls from Transdanubia.

As for the handle fragment V03F02 an additional aspect should also be taken into consideration, namely the typology of the ansa lunata handles, worked out by Károly Tankó. Based on the analogous examples known from the cemetery of Kleinklein, ${ }^{104}$ the fragment in question could be classified among the variant ' $a$ '. ${ }^{105}$

\subsubsection{Vessels with conical neck}

Among the sherds found in the barrow, the fragments of two big vessels of the type could be discerned. Interestingly, the joining fragments of the V05 vessel (Fig. 21) frequently have different colour. This, along with the fact that only fragments are known, could be interpreted as according to the literature an evidence suggesting that the vessel, already broken, was secondarily burnt. From a typological point of view, this specimen in question represents the common so-called Kegelhalsgefäß type in the pottery assemblage of the grave. In addition, numerous fragments are missing, thus we cannot be sure about the exact form of the entire vessel. This is, however, not a seldom occurring phenomenon among the potteries of the tumulus.

Due to the fact that the vessel in question is rather incomplete, hardly anything could be said about its - often discussed ${ }^{106}$ - function either in context of the funerary ritual or in context of the grave. It is worth mentioning however, that among the vessels from the tumulus a number of cups and little bowls can be found, which might have been used as a dipper. There are some documented instances, when such dipper was found inside of the Kegelhalsgefä $\beta,{ }^{107}$ which may allude to a possible function of these vessels in context of the grave, namely that they might have contained some kind of alcoholic beverage. On the other hand, this vessel type might have functioned as urns in the graves.

Although we were not able to reconstruct the vessel, an assumption could be made according to which the fragments labelled as V05F03 might be considered as the bottom of the Kegelhalsgefä $\beta$ in question, due to mainly the fact that the fragments under discussion possess comparable colour, material and size. The fragments V05F01 and V05F02 may be also parts of the vessel, considering their material, graphite-coated surface and similar bulging shape. As a consequence, it is rather a perplexing situation that we cannot surely link the different fragments of the Kegelhalsgfä $\beta$ because only the latter mentioned fragments bear any ornament, hence we are not in the position of being certain whether the V05 vessel had any decoration. As a result, it is problematic to estimate exactly how many vessels of this type were placed in the grave. On the other hand, considering the sherds coming from the mound it is highly probable that the aforementioned fragments belonged to only one Kegelhalsgfäß-type vessel.

The vessel type in question is extant since the Urnfield period, and in the following Hallstatt period it frequently appears in the assemblages of the eastern Hallstatt circle. Almost every excavated grave from the tumulus cemetery of Sopron-Várhely included at least one specimen of the type. ${ }^{108}$ In general, it is similarly frequent among the grave goods of the burials of the

104 Dobiat 1980, Taf. 67. 5-8.

105 Tankó 2005, Fig. 1.

106 Nebelsick 2000, 220; Preinfalk 2003, 67; Rebay 2006, 64; Müller 2007, 634-636; GutJahr 2015b, 178.

107 This phenomenon seems to be present already during the late Urnfield perid. TiEfENGRABER 2005, 29.

108 Eibner-Persy 1980, 36; Patek 1982a 12, 162; PAtek 1991, 280. 
Kalenderberg-group, ${ }^{109}$ furthermore, the Kegelhalsgefäßen occur equally frequently among the grave assemblages in the region of Styria. ${ }^{110}$

According to the literature, we can reckon with considerably different variants and distinct features from region to region. ${ }^{111}$ As a result, in the case of the V05 specimen we cannot solely rely on typochronological systems based on ceramic assemblages of distant cemeteries, ${ }^{112}$ for instance the cemetery of Kleinklein or Statzendorf.

In the Northern pre-Alpine region characteristic features of the vessel type are the high conical neck and the sharp shoulder-neck section frequently pronounced by a horizontal fluted line, in addition, they bear an extent and rich decoration. ${ }^{113}$ In the case of the V05 vessel only the fluted line can be recognised out of the aforementioned features.

Considering the representatives of the vessel type from the Kleinklein cemetery, we may argue that the V04 could be comparable with the specimens of Type 3 distinguished by Claus Dobiat, ${ }^{114}$ however - as earlier emphasised - we cannot take into account the chronological aspects worked out by the author.

In our view, it is more expedient to take into consideration the Kegelhalsgefäßen from the adjacent regions of Tihany. Firstly, the vessels of the type from the 'flat cemetery' near Halimba are worth highlighting. One can observe similarly modest decoration - confined to fluted lines and knobs on the shoulder - on these vessels, and their profile is mainly continuous, their neck is relatively short and a further comparable feature is the horizontal fluted line pronouncing the shoulder-neck section. In addition, analogous vessels have been found in graves of partly excavated cemeteries around Keszthely, however, these specimens bear somewhat more extensive decoration that the V05 vessel. ${ }^{115}$

Let us now discuss the V04 vessel (Fig. 20). There was no possibility of entirely reconstructing the vessel, however, it seems to be beyond any doubt that from a typological point of wiev it represents a variant with shorter neck than the V05 vessel. Hence, it could be taken into consideration that the vessel, although we cannot be sure about its exact dimensions, shoud be assigned to the type Kegelhalsgefäße mit niedrigem Hals defined by Katharina C. Rebay based on a metrical classification of the Statzendorf cemetery's potteries. ${ }^{116}$ Similar vessels, bearing similarly short neck seldom occur among the grave assemblages of the Sulmtal-group, neither tend to appear among the potteries of the Sopron-Burgstall cemetery. ${ }^{117}$

The vessels with short, conical neck mainly occur in Lower Austria, Moravia, and South Germany, ${ }^{118}$ and compared to the vessel from Tihany, they bear dissimilar features. The specimens

109 NeBELSICK 1997a, 54; REBAy 2006, 64.

110 Dobiat 1980, 70; EgG - Kramer 2013, 309.

111 Klemm 1992, 38; Preinfalk 2003, 54.

112 ReBAy 2006, 274; ToMEdi 2002, 224.

113 Eibner-Persy 1980, 36-37; Klemm 1996, Taf. 1; Nebelsick 1997a, 71.

114 Dobiat 1980, 68.

115 Keszthely-Árpád street: Honváth 2014, Fig. 10.7; Keszthely-Fenékpuszta Grave 1: ibid. Fig. 14.1; Keszthely-Fenékpuszta Grave 3: ibid. Fig. 17.2; Keszthely-Fenékpuszta Grave 5: ibid. Fig. 20.2.

116 REBAY 2006, 71.

117 Hitherto only one such vessel has been discovered. Alexandre Eibner-Persy defines it as a bombenförmiges Gefäß. EIBNER-PERsy 1980, 39.

118 Dobiat 1980; Rebay 2006, 71; Schumann 2012, 43; EgG - Kramer 2014, 310. 
known from for instance the Statzendorf ${ }^{119}$ and Grafenwörth ${ }^{120}$ cemeteries contrary to the V04 specimen tend to be entirely undecorated and have a more bulging body. Another dissimilar feature is that the largest diameter of the vessels tend to be situated farther than in the case of the V04 vessel.

As for V04's decoration, it can be stated that the vertical, narrow fluted lines are not the most common decoration elements of the Hallstatt Age in Transdanubia. Although not many examples are known, some could be enumerated here. Firstly, a bowl with similar decoration came to light from tumulus 89 of the Sopron-Burgstall cemetery. ${ }^{121}$ Another example is a vessel discovered in the Kismezo tumulus, ${ }^{122}$ furthermore, the same decoration can be seen on bowls with handle of the tumuli near Fehérvárcsurgó. ${ }^{123}$

\subsubsection{Situla-shaped vessel}

Due to considerable amount of missing fragments, there was no opportunity to entirely reconstruct the vessel V06 (Fig. 20). According to our observations this vessel's quality is worse than the average among the set placed into the grave; the surface shows traces of secondary burning, the once polished surface is cracked off and flaked off at several points.

The situla-shaped vessels began to spread at the beginning of the Hallstatt period. ${ }^{124}$ As for the region of Transdanubia, and above all in the area around Sopron, this vessel type is a characteristic and often-occurring piece of the grave goods, ${ }^{125}$ however the specimens there represent more profiled shapes than the vessel from the Tihany tumulus. Additionally, ceramic situlas are known from the excavated burial mounds near Vaskeresztes, which also resemble the typical shape that we see in the graves around Sopron. Moreover, the graves from Vaskeresztes pose the opportunity to compare situla-shaped ceramic vessels with a typical bronze situla. ${ }^{126}$ As a result we find it reasonable to believe that the specimens made of pottery might be copies of the bronze vessels. ${ }^{127}$ As earlier mentioned, the specimen from the Tihany tumulus - contrarily to the former examples - has a gently curving profile, based on which we consider it questionable whether it could also be seen as a copy of a bronze situla. ${ }^{128}$

Among the ceramic situlas known from the cemetery of Sopron-Burgstall, the specimens from Grave $81^{129}$ and Grave $224^{130}$ can be seen as exceptions, considering that they lack the typical profiled shape as well as any kind of ornamentation. On the other hand, the best analogy - regarding shape - of the vessel V06 might be the specimen from Grave 83. ${ }^{131}$

119 Grab A009: Rebay 2006, Taf. 7. PA38259; Grab A010: ibid. Taf. 8. PA56170; Grab A049: ibid. Taf. 41. PA42685; Grab A091: ibid. Taf. 63. PA42869; Grab A103: ibid. Taf. 77. PA42961.

120 Grave 4: Lochner 1988, Taf. 8.1; Grave 6: ibid. Taf. 10.1; Grave 11: ibid. Taf. 11.2.

121 Eibner-Persy 1980, Taf. 5.5.

122 LÁzÁr 1951, Tab. 2.a-b.

123 Petres - Jungbert 1997.

124 Hack 2002, 134; Preinfalk 2003, 59.

125 Dobiat 1980, 102; Eibner-Persy 1980, 39; PAtek 1982/83, 66; Fekete 1985, 60. It is not a seldom occurring situation that more than one ceramic situla is present among the vessels of a grave: PreINFALK 2003, 59.

126 FeKeTE 1985, Abb. 5.4; Abb 9.1-2.

127 Dobiat 1980, 102; Rebay 2002, 43.

128 Klemm 1992, quoted by Nebelsick 1997a, 67; Preinfalk 2003, 58; EgG - Kramer 2014, 316.

129 PATEK 1982a, Abb. 17.11.

130 PATEK 1982a, 148, Abb. 20.28,30.

131 PATEK 1982b, Fig. 10.15. 
The ceramic situlas occur rather seldom among the grave goods in the cemeteries around Kleinklein, ${ }^{132}$ hitherto only nine specimens are known. ${ }^{133}$ On the other hand, it is worth mentioning that the vessels of this type are mainly discovered in the most ostentatious graves of the cemetery. ${ }^{134}$ Another observation is that this type only occurs among the finds from the cemetery, there is no specimen from the Burgstallkogel of Kleinklein, which may suggest that the function of ceramic situlas is closely related to the burial rituals. ${ }^{135}$

The potteries of the Early Iron Age settlement of Szajk also include situla-shaped vessels, one of which has a gently curving shoulder and neck, ${ }^{136}$ similar to the V06 vessel. However, according to Csilla Gáti it is rather a pot considering its function than a situla-shaped vessel, which - as earlier mentioned - rather might have been a characteristic part of the funerary vessel sets.

\subsubsection{Henkelfußtasse}

This type is represented by only one of the tumulus' vessels, labelled here as V09 (Fig. 22). On the fragments of the vessel the graphited layer remained in a good state, however, on the outer surface of the sherds hardly can be any trace of graphite observed, due presumably to the secondary burning of the vessel. ${ }^{137}$ Similar to the other vessels, it was not possible to entirely reconstruct the vessel from the remaining fragments. In our view, this characteristic surface treatment on the inner side of the fragments might allude to the function of the vessel. According to the literature the graphite coating insulates the pottery to some extent, which suggests that the vessel was mainly used to contain - supposedly alcoholic - beverages. ${ }^{138}$

One of the most problematic circumstances regarding this vessel is that its handle is almost entirely missing - only a short stump can be seen on the widest part of the vessel. The missing handle would be a significant typological feature of the vessel. Nevertheless, the Henkelfußtasse from Tumulus 117 near Százhalombatta might offer a possible solution to this question, ${ }^{139}$ since its handle reminds us of one of the fragments among the ceramic assemblage of the Tumulus I of Tihany (F46). Based on the specimen from the Tumulus 117 we find it very probable not just that the fragment in question could have been a piece of the V09 vessel, but also that it could have had a handle raised high above the rim. This assumption is supported by the specimens found in Vaskeresztes, Krögelkogel and other sites from Styria.

The Henkelfußtasse found in the Vaskeresztes II tumulus can be divided into two distinct groups (tall and law) based on the ratio between the width and height of the cups. However, my assumption is that they had a similar function in the tumuli. The short, flat-handled cups can be found in both Vaskeresztes I and II but only the latter ones bear buttonlike plastic decorations on the handles that have high-drawn ansa lunatas.

132 Dobiat 1980, 102; HACK 2002, 134.

133 HACK 2002, 134; EgG - Kramer 2014, 316-321.

134 EGG - KRAMER 2014, 321.

135 SMOLNíK 1994, 29.

136 GÁti 2009, 66.

137 Not only the secondary burning could be responsible for removing the grapithe coating - KREITER ET AL. 2014, 130 - since this kind of surface treatment is also susceptible to the chemical conditions of the soil VADÁsz 1986a, 223.

138 Preinfalk 2003, 67; Rebay 2006, 48; MÜller 2007, 635.

139 Holport 1985, Fig. 23.2. 
According to the hitherto published information, the tall (deep) variation of the cups does not occur among the vessels of the Vaskeresztes I tumulus, ${ }^{140}$ and only broken cups were found in tumulus II of the site. Despite their fragmented state, it is obvious that they are comparable with the V09 specimen, especially the ones decorated with horizontal channelled lines on their lower part and "V"-shaped three-lined channelled motives under the rim. Moreover, we find it very probable that the tall (deep) Henkelfußschalen from the Vaskeresztes tumuli could also have possessed a high above the rim raised handle. As a result, the specimens in question are very good analogies of the V09 vessel.

Relatively near to Vaskeresztes a fragmented example of the vessel type has been unearthed at the Szombathely-Reiszi erdő site. ${ }^{141}$ In terms of shape it seems to be similar to the specimens from Vaskeresztes as well as from Tihany, however, it lacks any kind of decoration and the exact form of its handle is unknown. As far as I know this is the only specimen found in a settlement context.

In spite of the aforementioned - possible - similarities between the cup found in Grave 117 of Százhalombatta and the vessel from the Tihany tumulus, the former is considerably bigger and has a cylindrical lower part, which is clearly separated from the widest part of the vessel. ${ }^{142}$ However, perhaps we should also mention here a specimen of very peculiar shape with a short pedestal found in Tumulus II of Csönge, which could only be compared with the V09 vessel due to its size and handle. ${ }^{143}$ Among the potteries of the Csönge barrow, the cup in question represents a rather well-decorated specimen - this is also true in the case of the vessel set of the tumulus from Tihany. Thus we find it reasonable to believe that not just a typological category is to be distinguished, but these cups might also represent a distinct functional category among the vessels in context of the graves ${ }^{144}$ (Fig. 11).

In addition, the disturbed tumulus near Lovászpatona yielded a few two-handled cups according to the reports of the excavator, which also have graphite-coated inner surface. On the other hand, on the published pictures of the vessel set from the burial mound only the lower parts of such vessels are depicted. We can see fragments that possess decoration of horizontal channellings, which also remind us to the V09 vessel, however, considering their shape they are rather comparable with the low (one might rather represent the tall variant) ${ }^{145}$ Henkelfußschalen. Another problematic aspect of these vessels found in the tumulus near Lovászpatona is that the author remains silent about the dimensions of the cups in question, and does not mention why they should be considered to be two-handled specimens (we cannot see any indication on the published figures). ${ }^{146}$

Among the vessels of the Kröllkogel two cups with size and shape comparable to the V09 specimen can be found. In the case of these cups, the decoration consists of dotted lines and meander motives under the rim and around the narrowest part (above the bottom) of the vessel. ${ }^{147}$

140 FeKete 1985, 35-36.

141 ILON 2004, Tab. 62.7.

142 Holport 1985, Fig. 23.2.

143 LÁzÁr 1955, 207, Tab. 35.4.

144 Metzner-Nebelsick 2002, 135.

145 Mithay 1983, 55, Fig. 4.15.

146 Mithay 1983, 55, Fig. 4.11,14,15.

147 EGG - Kramer 2013, Taf. 72.1-2. 
Another example of the vessel type from Styria supports the possibility that the F46 fragment once belonged to the V09 cup. This specimen was discovered in Grave 2/91 at the site of Leibnitz-Altenmarkt. ${ }^{148}$ On the one hand its shape resembles the low variants of the tumuli near Vaskeresztes, and on the other hand the form of its handle shows similarities with the cups from the Kröllkogel and the Tumulus 117 of Százhalombatta (Fig. 12). It is worth mentioning that a similar handle fragment was found in Tumulus 31 of the Grellwald group of the Kleinklein cemetery, which pertains to a - fragmentary - cup, however, a different type. ${ }^{149}$

It might be worth mentioning that this cup type also occurs among the vessel sets of the burials of the Slovenian Hallstatt groups. Grave 8 of Vače excavated in 1878 yielded a specimen of low variant with a short conical pedestal. ${ }^{150}$ Another instance of the occurrence of such vessel type in the Slovenian region is known from Grave 138 of Tumulus 13 in the Preloge cemetery near Magdalenska gora. ${ }^{151}$ A common feature of both is that they possess knob-decorated, high-raised "horn-handles", and that they both stand on a short conical pedestal, a feature that the best analogies of the V09 vessel normally lack. On the other hand, the aforementioned specimens might also support the assumption that the F46 fragment belonged to the vessel in question as a piece of its handle, since they represent the characteristic shaped handle that we know from Leibnitz, the Kröllkogel as well as from Tumulus 115 of Százhalombatta.

However, it should also be mentioned that handled cups are in general popular among the vessel sets in various regions. They appear in various forms, some of them might to some extent resemble the cup from the Tihany tumulus. ${ }^{152}$

\subsubsection{Fußschüssel}

The only specimen of this type among the vessels in the tumulus is the one labelled as V15 (Fig. 26). As usual, there was no possibility of entirely reconstruct the vessel, on the other hand some features - indicating that the vessel was exposed to secondarily burning in broken state - could be identified, mainly adjoining but different coloured fragments. Among the vessels two types have characteristic conical shape - lids and the pedestal bowl, however, the rim of lids has considerably smaller diameter. We must emphasise on the other hand that the exact shape of the vessel under discussion is not known, since the supposedly conical lower part is missing. On the other hand, based on the short fragmented cylindrical part of the vessel, and considering that the diameter of this part rules out the possibility of being a handle - like in the case of the fragments IF23 and IF24 - we find it reasonable to believe that this specimen is rather a bowl - resembling a vessel type that is very frequent in the burial sets of the Kalenderberg-group, ${ }^{153}$ than a lid. At this point we cannot remain silent about the very fact that the vessel in question possesses quite extended decoration on its outer surface, which is a characteristic feature of the lids among the vessels of the tumulus. On the other hand we should remark that the so-called Kalenderbergfußschale possesses normally a profiled widening mouth contrarily to the V15 vessel that has a simple conical shape.

148 Artner 1996, 50, Abb. 2.; Hampel 2005, 241.

149 Bernhard - WeiHs 2003, Taf. 8.5.

150 Barth 1970, Taf. 40.2.

151 Hvala ET AL. 2004, Taf. 112.C.

152 Kaptol Tumulus 4, Grave 2: Vejvoda - Mirnik 1971, Tab. 3.10; Martijanec: Vinski-Gasparini 1961, Tab. 7.1.

153 The bowls with conical pedestals of the Kalenderberg group represent a certain typological variability to some extent nevertheless. 
This shape reminds us of the two pedestal - however undecorated - bowls from the Tumulus of Mesteri. Here the conical pedestal bowls from the Tumulus IX near Marz should also be mentioned, which are decorated with V-shaped channelled lines on their inner and outer surface, ${ }^{154}$ however, they are considerably smaller than the specimen of the Tumulus I of Tihany. Analogies are also known from the Tumuli near Langenlebarn, which represent the characteristic conical form with conical pedestal. These - similarly to the V15 vessel - are decorated only on their outer surface. ${ }^{155}$ It appears that the analogies of this vessel type occur predominantly northeast of the Alps - for instance, based on our present knowledge, no representative of it is known from the cemetery near Kleinklein in Styria.

\subsubsection{Lids}

In spite of the fact that neither of the lids could be entirely reconstructed, it can be highlighted that considering the funerary equipment of the tumulus, the lids represent the most decorated type among the vessels. The adjoining fragments bearing considerably different colour - as already noted several times - may suggest that the broken vessel they belonged to was exposed to secondary burning.

As for the function of the lids, it is frequently stated in the literature that this vessel type pertains to the situla-shaped vessels in context of the graves,${ }^{156}$ this, however, mainly applies in the case of the burials of the so-called Kalenderberg group. ${ }^{157}$ In the case of the vessels identified by the fragments from the Tihany tumulus one can easily perceive that much more lids were placed among the grave goods than situla-shaped vessels, which strongly suggests that no strict functional link could be assumed between ceramic situlas and lids in this burial context. On the other hand, we cannot even be sure whether any lid belonged to the V06 vessel. ${ }^{158}$ We would like to draw attention to the north-eastern part of Transdanubia, where - based on not too many instances - the lids are seemingly combined with bowls in burial contexts. ${ }^{159}$ Further regions, where the lids do not seem to be functionally related, are Styria and Slovenia, ${ }^{160}$ in addition, we can mention the Martijanec-Kaptol group that also provides instances when the lids rather covered vessels with conical neck than the seldom-occurring situlas. ${ }^{161}$

From a typological point of view we can generally distinguish two main categories among the lids, based on whether they are shaped with a knob or a handle. ${ }^{162}$ In our case this distinction

154 HEGER 1887, 44.

155 Preinfalk 2003, Taf. 8; Taf. 11.

156 Eibner-Persy 1980, 39; Dobiat 1980, 104; Klemm 1996, 190; Rebay 2006, 112.

157 Rebay 2006, 112.; EgG - Kramer 2013, 357. It is worth mentioning, though, that the lids almost entirely missing from the cemetery near Statzendorf, for instance.

158 Considering the diameter of the rim of the V06 vessel and the estimated diameter of the fragmented lids, only the V16 and V17 specimens could be taken into account as having belonged to the ceramic situla.

159 VADÁsz 1983, 48; VADÁsz 1986b, 252; VADÁsz 2003, 98. Although it is not exclusive, for instance a pottery situla came to light together with a lid from a tumulus excavated in the first half of the 20th century: VÉKONY - VADÁsz 1982, 4.

160 Dobiat 1980, 104.

161 Martijanec: Vinski-Gasparini 1961, 41; Kaptol Tumulus 2, Burial 2: VejvodA - Mirnik 1971, Tab. 3.8; Kaptol Tumulus 7: ibid. Tab. 10.7; It may also be worth noting that Tumulus 1 of Nagyberki-Szalacska might be another example, since among the vessels two lids as well as two fragmented Kegelhalsgefäße were found, although, located separately. Kemenczei 1974, 4. In the case of Grave 1 of Tumulus 1 near Dvorišce the lid covered a pot Vidović 1990, Fig. 6.

162 Eibner-Persy 1980, 40. However, it should be mentioned that there are other, less common forms of lids 
among the lids did not turn to be expedient because of the fragmented state of the lids among the grave goods of the tumulus under discussion, however, we would like to point out that only knobs of lids are known among the sherds (lF23, lF24).

In our view another distinction could be made among the lids based on the shape of the vessel, thus we can discern conical specimens (V19, V21, V22) and ones shaped as a spherical segment (V16, V17, V18, V20) among the lids found in the tumulus, ${ }^{163}$ although, there are flat disc-shaped specimens too (Fig. 25-26). An additional information regarding their function could be that in Tumulus 177 of Sopron-Várhely two lids representing different variants of the vessel type were found and each of them belonged to a pottery situla.

To begin with, we would like to discuss two fragments (IF23 and lF24) that belonged to different lids, in addition, we were not able to find any adjoining sherds, which also points out the remarkably fragmentary state of the ceramic assemblage from the tumulus (Fig. 27). On the other hand, these knob fragments represent easily identifiable variants. Based on the typological approaches of Dobiat and Eibner-Persy, the two fragments could be identified as lids with 'Griffknopf. ${ }^{164}$ It is noteworthy, nevertheless, that the lids of this variant at Sopron-Várhely are solid, ${ }^{165}$ contrary to the fragments in question. Based on the lF24 fragment we can say with some confidence that among the lids of the tumulus there were specimens open from the knob. Such vessels are known from Transdanubia. ${ }^{166}$ As for the closed variant, in our case just two fragmentary lids could be mentioned - V22 and lF23.

Based on our present knowledge the best analogies of the IF23, IF24 knob fragments could be discovered among the vessels from Slovenia listed under the Type 4 of lids by Janez Dular. ${ }^{167}$ It may be worth mentioning that not just the shape of the Slovenian specimens resemble the ones from the Tihany tumulus, but they bear similar fluted decoration on the knob. On the other hand, we should point it out that the lids for instance from Stična, albeit they have similar knobs, cannot be taken into consideration as analogous vessels because of their straight or slightly inverted rims.

We are not in the position to say anything further about the typological characteristics of most of the lid fragments, since in general it is not possible to ascertain what kind of handle they had or whether they were closed or open to the upper part. On the other hand, we are able to conclude that none of the lids have a shape that is not hitherto known from the Early Iron Age assemblages of Transdanubia. Their decoration, however, include interesting features. One of the most significant motives can be seen on the fragments of the V18 vessel that may be led back to a basic swastika motive. Similar - in this case plastic - motives can be recognised on the firedogs found on the Poštela hillfort. ${ }^{168}$ Moreover, it seems to be obvious that the swastika motives on ceramics concentrate predominantly in the area of

found in grave context, i.e. Szalacska 1: Kemenczei 1974, Fig. 2.5-6; Sopron-Várhely 177: Patek 1991. Abb. 6.2/b; Abb. 7.5.

163 EGG - KRAMER 2013, 357

164 Eibner-Persy 1980, 40; Dobiat 1980, 104.

165 Eibner-Persy 1980, Taf. 10.6, Taf. 12.5.; Eibner-Persy 1980, Taf. 98.6.

166 Keszthely-Vadaskert Grave 6: Horváth 2014, Fig. 5.10; Tumulus 114 at Százhalombatta: Holport 1985, Fig. 8.2; Tumulus 2 near Csönge: LÁzÁr 1955, 207, Tab. 34.15.

167 Dular 1982, 79-80, Tab. 27.275-280. Magdalenska gora-Preloge Tumulus 2, Grave 47: HvalA ET AL. 2004, Tab. 46.A,23; Magdalenska gora-Voselca Tumulus 2, Grave 14: HvalA ET AL. 2004, Tab. 136.B,1.

168 TeRŽAN 1990, Tab. 26.3; TERŽAN 1990, Tab. 29.1. 
today's Slovenia. ${ }^{169}$ In the case of the shreds of the V17 lid the fluted and graphited, crossed lines remind us of the decoration of the exceptional specimens found in Tumulus I of Nagyberki-Szalacska. ${ }^{170}$ Another analogous motive can be observed in the case of an undefined vessel from an Early Iron Age settlement excavated at Ordacsehi ${ }^{171}$ and on a lid found in the burial mound near Nové Dedinka. ${ }^{172}$ As for the decoration on the rim of the V21 lid, similar motives appear on a vessel with conical neck found in Tumulus 2 near Wetzelsdorf. Nevertheless, in this case they are not composed of shallow, fluted lines, but they are incised. ${ }^{173}$

\subsubsection{Storage vessel}

It is possible that the only vessel to be entirely reconstructed is the one labelled as V07 (Fig. 22 ). Its broken pieces could be easily detected among the ceramic fragments of the tumulus, due mainly to the rather bad quality of its material, however, the final reconstruction of the vessel is going to need a restorer's attention. Based on our observations this storage vessel is exceptional among the funerary equipment of the tumulus considering that it could have been placed into the grave in complete form.

From a typological point of view, the vessel has some characteristic features, for instance its slight S-profile side and the cordon on its neck decorated with finger-tip impressions. Another noteworthy trait about it is the coarse quality of the vessel.

A good analogy of the V07 vessel - regarding shape and the characteristic decoration on the neck - have been found in Tumulus VI of Nové Košariská. ${ }^{174}$ Secondly, among the spectacular potteries of Tumulus I near Vaskeresztes we can also identify the vessel type in question - among the vessels of rather good quality the representatives of this storage vessel type appear to be coarse-tempered, and they bear a very similar decoration as the V07 vessel. This vessel type also occurs among the funerary equipments of Tumulus 34 of Sopron-Burgstall. However, a vessel known from the Tumulus of Kismező possesses a slightly different shape. With regards to its decoration and bad quality, we would like to consider it as an adequate analogy, in a similar sense should be mentioned the Tumulus I of Nagyberki-Szalacska, since the grave in it also contained at least one coarse storage vessel with shape similar to the V07 specimen. ${ }^{175}$ Among the specimens from the tumulus of Vaskeresztes, Kismező and Tihany another similarity - beside their characteristic decoration - could be ascertained; they appear to be coarse ware among pottery made of high quality.

Set aside that the specimens of this type occur in tumuli, there are known instances when such vessels are included among the funerary equipment of so-called Flachgräber, as we can see in Grave 8 of the cemetery near Tatabánya-Dózsakert. ${ }^{176}$ This vessel could be also considered as coarse pottery and is decorated with finger-tip impressed cordon. Fragments bearing this characteristic decoration are also known from the cemetery near Halimba; ${ }^{177}$

169 Brosseder 2004, 297; Abb. 190.

170 Kemenczei 1974, Fig. 2.5-6. It is noteworthy that we do not have any indication that we should reckon with such ring-shaped handles that can be seen on these vessels from Szalacska.

171 KulCSÁr 2007, 189.

172 StudeníkOvá 1994, Obr. 7.1.

173 Bernhard - Fuchs 2004, Taf. 7.1.

174 Pichlerová 1969, Tab. 33.1.

175 KemenCZei 1974, 4.

176 Groma 2015, Abb. 5.12.

177 Lengyel 1959, Taf. 36.7; Taf. 47.16. 
according to the description of the fragments, they could have belonged to storage vessels similar to the V07 specimen.

In addition, it is worth noting that the vessel type appears already in the Ha B2-3 phases; instances could be found among the cremation graves of the cemetery Hadersdorf am Kamp, and it is also worth mentioning that specimens of the vessel type frequently occur in Transdanubia in the Urnfield period. ${ }^{178}$ Furthermore, unlike most of the aforementioned vessel types, storage vessels are known among the potteries of settlements. Biba Teržan published several fragments found on the settlement of Poštela; these sherds often bear the same cordon decoration and resemble a very similar shape as the V07 specimen. We can name several Iron Age settlements in Transdanubia from which fragments of this vessel type are known, just to name some instances: Szajk, ${ }^{179}$ Letenye, ${ }^{180}$ Sé-Doberdó, ${ }^{181}$ and Gór-Kápolnadomb. ${ }^{182}$

Due to the very fact that these storage vessels mentioned above can be dated from the $\mathrm{Ha}$ B2-3 to the Ha D phases, we cannot take the V07 specimen into consideration regarding the chronological situation of the tumulus I of Tihany.

\subsubsection{Small bowls}

Besides the so-called Kegelhalsgefäße the small bowls are considered to be the most frequently occurring vessel type among the ceramic assemblages of the burials of the eastern Hallstatt circle. ${ }^{183}$ Basically, the fundamental definition of cups (small bowls) and bowls are the same (i.e. the diameter of the rim is substantially larger than the height of the vessel). Considering the vessels among the grave goods of the tumulus there are two - regarding size - easily distinguishable groups of vessels that meet that definition: the above discussed handled bowls and cups.

Although this system could be more thoroughly elaborated, in this case we would like to distinguish between two basic variants of cups. The globular shape of the V11 and V12 cups is rather well-known among the funerary vessel sets of the eastern Hallstatt circle's graves (Fig. 23).

The Tumulus I of Csönge yielded four globular cups that also have similar omphalos-shaped bottom. Their inner surface is decorated with graphited lines constituting geometrical motives. Due to the fragmentary state of the V11 vessel, we cannot give a detailed comparison with regards to the constituent motives of their decoration.

Several analogous vessels are known among the vessel assemblages of "flat-cemeteries", for instance the cemetery excavated near Nagydém. ${ }^{184}$ Similar shape could be observed in the cases of several cups found in the graves found near Halimba, however, remarkably they bear the graphite lines on their outer surface. ${ }^{185}$

178 PATEK 1968, 111-112; KAlicz-Schreiber Et AL. 2010, 254.

179 GÁti 2009, Fig. 4.8-9.

180 Horváth 2012, Fig. 3.37.

181 GÁL-MolnÁr 2004, 179.

182 ILON 2001, Taf. 8.3. We should also mention that the ceramic assemblage from the settlement could not be dated more accurately in the Ha B-D periods. ILON 2001, 248.

183 Klem 1996, 190; Rebay 2006, 51. An interesting fact is that in the case of the Halimba cemetery these vessels were the most numerous: LeNGYEL 1959, 163.

184 Grave 12: NAGy 1939, 41; Grave 20: ibid. 43; Grave 21: ibid. 43; Moreover, among the stray finds of the cemetery there are two omphalos-bottom globular cups decorated with comparable motives: ibid. Fig. 4.5,15.

185 Grave 12: LeNGYEL 1959, Tab. 36.10. 
Based on the profiled side of the vessels another type of cups apparent in burial sets and among settlement finds since the Urnfield period ${ }^{186}$ is discernible, represented by two cups (V13, V14) in the assemblage (Fig. 24). An analogous, undecorated specimen was found in Tumulus $4^{187}$ and Tumulus $224^{188}$ of Sopron-Burgstall, and the upper part of several pedestal bowls found during the excavations of E. Patek also resemble the fragments' shape. ${ }^{189}$ The assumed link between these vessels and the fragments under discussion is also supported by the fact that the enumerated pedestal bowls from Sopron bear the decoration consisting mainly of flutes between the rim and carination on their side, similar to the V13 and V14 specimens. Similar profiled side is observable on cups that came to light from Tumulus $5^{190}$ and $14^{191}$ at Vaszar-Pörösrét.

On the other hand, we might also propose another identification of these fragmentary vessels. We have already pointed out that the ceramic assemblage discovered under the tumulus also comprises two fragments which seem to resemble a characteristic handle type of lids known mainly from today's Slovenia. ${ }^{192}$

Due to its horizontally faceted rim and decoration on the inner surface, the V10 vessel should be assigned to a different type of the cups ${ }^{193}$ (Fig. 23). This type along with the horizontally faceted decoration is also in use in Transdanubia and the adjacent regions from the beginning of the Urnfield period to the Early Iron Age, ${ }^{194}$ although, based on the the analysis of the ceramic tradition in South Pannonia, North-Eastern Slovenia and Eastern Austria this type of small bowls is considered to be particularily wide-spread only from the Early Iron Age. ${ }^{195}$ In the case of the Sulmtal cemetery small bowls with horizontal faceted, inverted rims are characteristic of the first phase. ${ }^{196}$

\subsubsection{Clay pearl}

Since it is made of clay, we should briefly discuss the clay pearl among the ceramic finds of the tumulus (inventory no. 72.10.35). It is a globular, vertically pierced pearl decorated with densely spaced vertical ribs. There is no firm indication whether only one piece of this type was placed among the grave goods, however, we find it reasonable to believe that it certainly had a different function than the disc-shaped bone object (inv. no. 72.10.34) that could be considered with greater likelihood to be a spindle whorl. ${ }^{197}$

With regard to shape, size and decoration, analogous objects came to light from Tumulus I of Vaszar, ${ }^{198}$ from Grave XXXIV of the cemetery near Halimba ${ }^{199}$ and from several graves of

186 Rebay 2006, 57.

187 Eibner-PERsy 1980, Taf. 1.2.

188 PATEK 1982a, Abb. 20.12.

189 PATEK 1982a, Abb. 20.19,21-25

190 PATEK 1993, Abb. 79.3.

191 PATEK 1993, Abb. 87.7.

192 See note 165.

193 ReBAy 2006, 59.

194 Tiefengraber 2005, 127; Rakvin 2015, 84.

195 Metzner-Nebelsick 2002, 136; Hellerschmid 2006, 259; Dular 2013, 57.

196 Dobiat 1980, 115.

197 However, in the case of the cemetery near Statzendorf similar objects were described as spindle wohrls, the author - due to the decorated specimens - does not rule out the possibility that they had another function, namely, they could have been pearls. ReBAy 2006, 113.

198 Mithay 1980, Abb. 4.5.

199 Lengyel 1959, 163. This grave also yielded a similar but undecorated pierced clay pearl. 
the cemetery of Nagydém-Középrépáspuszta. ${ }^{200}$ These were defined - contrary to our opinion - as spindle-whorls, however, László Nagy in some cases writes about clay pearls. ${ }^{201}$ The similar, decorated and pierced objects form the Early Iron Age grave of Keszthely-Árpád utca have been also defined as pearls; truth to be told, they bear more delicate features with regard to shape and decoration as the specimens enumerated above. ${ }^{202}$ Considering the surrounding region of the tumulus under discussion, it can be stated that clay pearls are common among the grave goods.

\subsubsection{On the ceramic fragments from the tumulus}

Here we would like to present some of the fragments that could not be assigned to either of the vessels, nevertheless, they bear noteworthy features. First of all, the horizontal fluted decoration of the rF28 seems to be characteristic enough to let us meet the conclusion that it represents the only fragment of the vessel among the pottery finds of the tumulus (Fig. 27). Although it is only one fragment, it appears to be a part of a vessel similar to one found in one of the tumuli of Zalaszántó. ${ }^{203}$ This exemplar and that found in a grave on the slopes of the Somló Hill ${ }^{204}$ came from undocumented and rather uncertain situations. It should also be mentioned that the horizontal fluted decoration on the necks of the vessels is a common feature of the pottery production of the Sulmtal group. ${ }^{205}$ Moreover, this fragment deserves attention also because it is generally assumed that the horizontal cannelures on the vessels' neck seem to be a characteristic feature of the Ha C2-D phases. ${ }^{206}$

One of the most remarkable fragments of the tumulus is F48, shaped as a bird's head (Fig. 30). This kind of plastic decoration is not an uncommon occurence among potteries of the tumuli of the eastern Hallstatt circle (Fig. 13). In our view, the best analogy of this piece came to light from the tumulus I of Somlóvásárhely, ${ }^{207}$ unfortunately, this is also a fragment, and so it cannot be any help to us finding what kind of vessel it belonged to. On the other hand, the Mesteri tumulus, and the barrow near Bullendorf offer a possible answer to this question, as they both yielded lids decorated with a bird-shaped handle. ${ }^{208}$ Thus it is conceivable that the F48 fragment could have also belonged to a lid, ${ }^{209}$ but we lack direct evidence. This assumption is also supported by the tumuli of Nove Košariska and Pillischdorf, in which some of the lids bear plastic decoration of similar shape. ${ }^{210}$ There are, however, contradictory instances. In the case of the burials of the Martijanec-Kaptol group, similar bird-shaped figures are frequent decoration on the shoulder of the vessels with short conical neck. ${ }^{211}$ Form Tumulus 27 at Sopron-Burgstall a bowl came to light, whose rim bears plastic decorations featuring bird

200 Grave 14: NAgY 1939, 41; Grave 20, Grave 22: NAGY 1939, 43.

201 NAGY 1939, 43.

202 HoRvÁth 2014, 85

203 MÁrton 1933, Tab. 26.1.

204 Gallus - Horváth 1939, Taf. 57.1.

205 Bernhard - Weihs 2003, 218.

206 Hellerschmid 2006, 244.

207 Horváth 1969, Fig. 2.4; Patek 1982/83, Taf. 23.7.

208 LÁZÁr 1951, Tab. 26.4.

209 Siegfried-Weiss 1979, 82.

210 Nové Košariska, Tumulus 6: Pichlerová 1969, Tab. 32; Pillischdorf: Barth 1970, Taf. 6.

211 Šimek 2004, 107. For instance: Dvorišče 1: Vidović 2003, Tab. 3.1; Tab 3.4. 
figures. ${ }^{212}$ Based on vessels from the Kröllkogel ${ }^{213}$ and the Tschoneggerfranzltumulus $2,{ }^{214}$ the bird-shaped plastic decoration might be linked to bowls and cups too. It is also worth mentioning that all of the above enumerated analogies suggest that originally the entire body of the bird must have been formed.

The bF40 fragment (Fig. 29) is considered to be a remarkable piece since this is the only sherd based on which it could be convincingly deduced that among the grave goods of the tumulus we might reckon with at least one bowl with a conical pedestal. ${ }^{215}$ Its form and the horizontal fluted lines on its upper part strongly suggest that the vessel to which it once belonged to might find its best analogies among the pedestal bowls of the Kleinklein cemetery. ${ }^{216}$

The sF43 and sF44 fragments are both made of well levigated clay and have black burnt surface (Fig. 30). Despite the fact that both have decoration consisting of graphited, wide angular lines (possibly rhombus motives), there is good reason to believe that they belonged to different vessels, since the $\mathrm{sF} 43$ - contrary to the $\mathrm{sF} 44$ - fragment bears the decoration on its inner surface. However, it is not easy to assign the former fragment to either of the above discussed types, and it is only an assumption, based on the inner decoration, that it is a piece of a bowl or a cup. ${ }^{217}$ It is not less problematic to determine the type of the vessel the fragment sF44 once belonged to. Due to the horizontal fluted line marking the border of the vessel's shoulder and the neck, it is conceivable that we are dealing with a specimen comparable with the above discussed big handled bowls. However, similar decoration has not been encountered on either of the vessels of the type, neither in the case of the Tihany tumulus, nor any of the burials in Transdanubia. On the other hand, north of the Danube, there are several tumuli that yielded vessels bearing this characteristic motive. In fact, some believe, that the rhomboid pattern was mainly used as part of the vessels' decoration in the northern and northeastern pre-Alpine regions. ${ }^{218}$

As for the fragments labelled as F47 (Fig. 31), one could argue that these horn-shaped applications could have belonged to a conical vessel similarly to the example from the Csönge tumulus ${ }^{219}$ or from the Grellwald 20 mound. ${ }^{220}$ On the other hand, the possibility should not be ruled out that they once decorated the handle of a bowl like the one found in Grave 3 of the Keszthely-Fenékpuszta cemetery. ${ }^{221}$ There are, however, other possibilities as well. Just to name one, the horns of the bull-heads on the widely-known vessels from Vaszar seem to be quite similar. ${ }^{222}$

Based on their various spectacular decoration the fragments labelled as F49 should be considered as an exceptional piece among the ceramic finds form the tumulus (Fig. 31). The

212 PATEK 1982/83, 68.

213 EgG - Kramer 2013, 359.

214 Dobiat 1980, Taf. 55.2; Hansen 2007, 200.

215 In the case of the above dicussed V15 vessel, it is not sure whether it had a conical or a cylindrical pedestal. Conical pedestals frequently occur in the tumuli at Sopron-Várhely.

216 Dobiat 1980, 89-90.

217 For instance, a black burnt bowl with graphited inner decoration is known from Nyergesújfalu, the basic motive - hence is swastika - consists of angular lines. PAtek 1993, Abb. 106.5.

218 Studeníková 1994, 43; Bosseder 2004, 159.

219 LÁzÁr 1955, Tab. 32.6.

220 Dobiat 1980, Taf. 66.1.

221 Horváth 2014, Fig. 18.7.

222 HoRváth 1969, Fig. 19; Fig. 26. 
most characteristic one is the rectangular lined, plastic spiral motive; a similar decoration could be identified on one of the fragments found in the first tumulus at Szalacska. ${ }^{223}$ The spiral seems to have been a fashionable element of the ceramic decorations in the case of the Szalacska hillfort's community. ${ }^{224}$ Plastic, rectangular spiral motive can be seen on one of the vessels with conical neck found in Grave 4 of the cemetery excavated near Maissau, in Lower Austria. ${ }^{225}$ Plastic spirals are also known from regions north as well as south of Tihany, for example the vessel with conical neck found in Grave C054 of the Statzendorf cemetery, ${ }^{226}$ or the Kragenhalsgefä $\beta$ found in tumulus 12 of the Goričan cemetery ${ }^{227}$ The latter vessel bears a plastic decoration comparable with the one known from Szalacska. ${ }^{228}$ Beside the above presented spirals, the F49 fragment's decoration consists of triangular patterns to which incised spirals connect. Obviously, similar decoration mainly appears on the potteries of Sopron-Burgstall. ${ }^{229}$ It has been mentioned that decorations including spirals often appear on vessels with conical neck, however, the F49 fragment could not have belonged to this type since two parts of the rim closing an angle of nearly 90 degrees is observable on the adjoining fragments, suggesting that the fragments rather belonged to a pedestal with openwork decoration. This kind of pedestal is well-known among the potteries of the Sopron-Burgstall cemetery ${ }^{230}$ and some of the tumuli near Nové Kosariška also yielded such specimens. ${ }^{231}$ But it should be taken into consideration that such dense and rich decoration does not tend to appear on pedestals but usually on lids. If we consider the potteries of the Tihany tumulus it appears to be truth, too, the F49 fragments seem to be exceptions in this regard.

\subsubsection{Thoughts on the fragmentary state of the pottery finds of the tumulus}

Having been working with the ceramic fragments, I am prepared to agree with Uzsoki's belief that no vessel could be entirely reconstructed, ${ }^{232}$ on the contrary, there are considerable number of vessels represented by only a handful of sherds. I would like to address this matter in detail, since Uzsoki devoted special attention to this fact when he expressed his opinion according to which in the case of the Tihany tumulus one cannot reckon with a burial. ${ }^{233}$ But can we rule out the possibility that the main reason for the lack of entire vessels should be sought among the circumstances of the excavation? Certainly not. The most problematic is that a great part of the mound was removed by a bagger. It is therefore

223 Kemenczei 1974, Fig. 3.7.

224 The plastic spiral on the sherd to some extent resembles the painted meander motive on the vessel with conical neck discovered in tumulus 3: KeMENCZEI 1976, Abb. 1. This motive also appears for instance on two vessels of the Martijanec mound: VInSKi-GASPARINI 1961, Tab. 5.6. It is noteworthy, however, that this characteristic, painted meander motive is distributed through the eastern Hallstatt circle. BROSSEDER 2004, Abb. 192.

225 Pescheck 1948, Abb. 8.

226 Rebay 2006, Taf. 179. PA45274

227 Vidović 2003, Tab. 3.5.

228 Kemenczei 1974, Fig. 8.

229 Tumulus 34: Eibner-Persy 1980, Taf. 41.3, ibid. Taf. 42.7; Tum. 59: ibid. Taf. 56.8; Tum. 89: ibid. Taf. 63.1-2; Tum. 137: ibid. Taf. 78. 4; Tum. 147: ibid. Taf. 88.3; Tum. 215: РAтEK 1982a, 150.

230 Eibner-Persy 1980, 41; PAtek 1982a, 166.

231 Tumulus 3: Pichlerová 1969, Tab. 14.1-3,5; Tum. 6: ibid. Tab. 38.3-4, ibid. Tab. 39.6,12.

232 Uzsoki 1986, 248. It is worth mentioning again that the assemblage needs the expert attention of a restorer, nevertheless.

233 Uzsoki 1986, 248. 
not possible to ascertain whether there were pottery fragments in the fill of the mound. ${ }^{234}$

However, according to the literature, it is not an isolated phenomenon that the potteries from Early Iron Age tumuli are in fragmentary state and cannot be entirely reconstructed. It has been already mentioned that a very similar situation was met during the excavation of Tumulus 75 of the Százhalombatta cemetery, and no vessels could be reconstructed. ${ }^{235}$ Sándor Gallus reached a similar conclusion about the tumuli of the Szalacska cemetery excavated by him. ${ }^{236}$ According to Tibor Kemenczei entire vessels seldom occurred among the grave goods during the excavation of the mounds in the early 1970's. ${ }^{237}$ Kemenczei also argues that some of the vessels had been already broken into pieces by the time they were placed into the chamber grave of Tumulus $1 .{ }^{238}$ Sándor Mithay also believes that some of the vessels of the Vaszar tumuli broke into pieces perhaps during the funeral. ${ }^{239}$ It has also been observed in the case of Tumulus 114 near Százhalombatta. ${ }^{240}$ Several tumuli in the North-Eastern and Eastern pre-Alpine region also revealed similar examples of the phenomenon. ${ }^{241}$ That this characteristic feature of the potteries placed in graves do not confine to the tumuli is clearly shown by the burials of the "flat" cemetery of Keszthely-Vadaskert. ${ }^{242}$ Based on the aforementioned examples I would like to disagree with Uzsoki's opinion, explained above. I would not conclude that the Tihany tumulus contains no grave based on the fragmentary and incomplete state of the potteries.

Now, I would like to discuss another characteristic feature of most of the potteries found under the Tihany tumulus, which is not entirely unrelated to their fragmentary state. In the case of the great majority of the sherds signs could be observed alluding to that the potteries were exposed to high temperature. This is mainly suggested by the fact that in many cases the adjoining pieces have entirely different colours. There is also reason to believe that the vessels were broken during this secondary burning. There is a piece among the sherds, on the fracture of which a fragment of bronze can be seen, that possibly attached to the ceramic due to the exposure to heat that to some extent melted the piece of metal. Interestingly, regarding the pottery fragments found in the Szalacska tumuli, Tibor Kemenczei mentions that some of them shows clear signs of secondary burning, suggesting that the vessels they once belonged to might have been placed onto the pyre, next to the deceased. ${ }^{243}$ It is generally believed that

234 There are several cases, where it was noticed that sherds occured outside of the grave itself, in the fill of the mound. In Transdanubia, such cases are known from Szalacska: Kemenczei 1976, 204. But if we consider a wider region we can encounter other instances of the phenomenon, like Poštela-Lepa Ravna: TERžAN 1990, 316, 323; Saazkogel tumulus 106: LIPPERT 2008, 80; there are tumuli of the Kalenderberg group as well as of Upper Austria presenting examples of this phenomenon NeBELSICK 1997a, 60; EGG 1985, 300. It is worth noting, however, that the reason for this might be sought elsewhere than the rites of the funeral. The plunderings of the graves should be reckoned with, as well as there is a possibility that the ceramic fragments in the fill of the mound originate from a former settelement, like it was observed in case of the tumuli near Fürholz: WeDENIG 1997, 119.

235 Holport 1985, 26

236 KABAY 1960, 47, 50.

237 KemenCZei 1974, 11; KemencZei 1976, 204.

238 Kemenczei 1973, 329; Kemenczei 1974, 4; Kemenczei 1976, 204.

239 Mithay 1980, 66.

240 Holport 1986, 95.

241 For instace: Badersdorf: Kromer - Pescheck 1957, 56; Langenlebarn tumulus 3: Preinfalk 2003, 51; Pillischdorf: Heger 1879, 236; Pinkafeld tumulus 2: BARB 1937, 104.

242 HoRváth 2014, 65.

243 Kemenczei 1976, 204. 
some of the grave goods were placed next to the dead before the cremation. ${ }^{244}$ As for Szalacska, this assumption is supported by the fact that the fragmentary vessels came to light, in several cases, from a context including burnt remains and great quantity of charcoal, and this seems to be comparable with the situation found under the stone heap in the Tihany tumulus.

Do we encounter similar phenomena in the tumuli of what is thought to be the largest tumulus cemetery of the eastern Hallstatt circle? There are a number of cases when, similarly to the Tihany tumulus, the vessels are only represented by some sherds on which signs of secondary burning can be deciphered. An example could be the Grellwald 31 tumulus. ${ }^{245}$ Claus Dobiat also noticed that in several cases the potteries were intentionally broken to pieces during the funeral. ${ }^{246}$ This rite and the custom of throwing pottery fragments onto the tumulus during its building are supposed to be frequent and in close relationship with the Brandflächergräber of the Sulmtal group in Stryia. ${ }^{247}$ This statement is also supported by the excavated tumuli of the Saazkogel. ${ }^{248}$ But possibly one of the best examples comparable with the Tihany tumulus from this point of view is the Wiesenkaisertumulus 4. Interestingly, among the potteries found under the mound two groups could be distinguished. Firstly, next to the remains of the funeral pyre stood two Kragenhalsgefäße; contrary to the other ceramic finds, it was possible to fully reconstruct them. The second group is formed by vessel fragments scattered over the area of the Bustum; sherds belonging to the same vessel were found away from each other, and they display signs of secondary burning. ${ }^{249}$

Above I focused merely on emphasising the existence of fragmentary ceramics in tumulus graves, however it must be also mentioned that usually entire or restorable vessels are also present in these contexts. Thus, it seems reasonable to believe that in certain cases a dual custom of ceramic grave offerings can be envisaged. During 1991-92, a Hallstatt Age "flat" cemetery was excavated at Leibnitz-Altenmarkt. Interestingly, in a pit nine, to some extent fragmentary vessels came to light, some of the sherds were missing, and similarly to the above mentioned instances the pieces bore signs of secondary burning. ${ }^{250}$ According to Ulli Hampel's interpretation it was not a grave but a ceramic depot in context of the cemetery. ${ }^{251}$ In addition, a similar situation was found in the Masser-Kreuzbauer cemetery in the Sulmtal; the finds were fragments from which the vessels could not be restored. ${ }^{252}$ It seems to be a proper explanation that these depots seem to represent customs of the funeral rituals that cannot be linked to the grave goods. There are tumuli where a similar situation is visible. It seems to be a general feature of the tombs with dromos that pyre remains in secondary position mixed with burnt ceramic fragments and to some extent melted bronze object could be found in the

244 Kemenczei 1976, 204; Nebelsick 1997b, 384; Rebay 2006, 49; Novinszki-Groma 2017, 163. If the vessels had presumably been on the pyre during the cremation, it would be reasonable to believe that nearly all of the fragments of a vessel should be the remains of the funeral pyre discovered. Therefore, the question is how it could be interpreted when the pyre remains are found, however none of the vessels exposed to the fire could be entirely reconstructed. Maybe the vessels had already been broken at an earlier point of the funeral ritual.

245 Bernhard - Weihs 2003, 215. Since it was a relatively recent excavation, I am inclined to believe in the justness of this observation.

246 Dobiat 1980, 71.

247 LIPPERT, 2008, 89.

248 Lippert 2008, 78-79.

249 HACK 2002, 131.

250 HAMPEL 2005, 237.

251 HAMPEL 2005, 239.

252 BernhARD - WeiHs 2003, 94. 
corridor leading to the chamber, while in the chamber a set of to some extent intact vessels tend to be discovered. ${ }^{253}$ This leads to the concept of two different types of ceramic grave offerings in the tombs of the eastern Hallstatt circle. ${ }^{254}$ According to this, one vessel set is placed into the grave, hence they are considered to be grave goods, ${ }^{255}$ on the other hand, there are vessels that were to some extent destroyed - along with different elements of attire, perhaps tools and weapons - during the cremation, and as a result they seem to be more linked to the event of the funeral than the tomb itself, ${ }^{256}$ (hence the term: Scheiterhaufenkeramik ${ }^{257}$ ) thus it is reasonable to deem them as pyre goods. ${ }^{258}$

This duality among the vessels is obviously not visible in the case of the Tihany tumulus, in fact, it seems more likely - based on my present knowledge - that all of the ceramics found under the tumulus under discussion can be seen as Scheiterhaufenkeramik. This assumption is also supported by my interpretation of the burial form, as it might be a so-called Bustumgrab. Based on the example of the Bustumgrab of the Wiesenkausertumulus 4 this concept seems to be likely, since here only two vessels were restorable, only they displayed no burning marks, contrarily the great majority of the potteries. ${ }^{259}$ In the case of the Tihany tumulus some 40 vessels could be distinguished, among which only a few are represented by considerable amount of sherds.

\subsection{The metal finds of the tumulus}

As it has been already pointed out, although in Uzsoki's reports metal finds of considerable number are mentioned, only a small amount is present in the museum's inventory. Again, it is problematic that there is no indication why the chiefly broken metal pieces have been assigned to the same or to different inventory number, hence we cannot be sure whether the fragments under the same number might have belonged to the same tool or decoration element/jewellery. We do not know anything about their position under the tumulus either.

\subsubsection{Iron rings}

First of all, at least two similar iron rings have been found among the metal finds that came to light from the tumulus (or to be more precise, three can be found among the objects in the museum ${ }^{260}$ (Fig. 14.1). The most important question regarding these iron rings is whether they were parts of a horse harness. It should be noted that among the metal finds no pieces of horse bit can be found, which would strongly suggest that elements of horse harness had also been placed among the grave goods.

253 One of the best documented examples is the Kröllkogel, although, this pattern could be ascertained in case of Vaskeresztes: Fekete 1985, 41; Sütő: VAdÁsz 1983, 32; Novinszky-Groma 2017, 162-163; Kaptol: PotreBICA 2011, 104; Strettweg 2: Tiefengraber - Tiefengraber 2015, 256-257; Jelžabet 2: ŠimeK 1998, 497-498. However, it must be noted, it appears that this kind of duality of the ceramic grave offering does not confine to the tombs with dromos. For instance, this duality seem to occur in case of Tumulus 1 of the cemetery at Nagyberki-Szalacska and the Wiesenkaisertumulus 4 of the Sulmtal cemetery.

254 Egg - Kramer 2013, 404; Tiefengraber - Tiefengraber 2015, 256-257.

255 MCKinley 2013, 150-151.

256 Potrebica 2012, 20; Potrebica - Mavrović Mokos 2016, 47-48.

257 Schumann 2015, 251.

258 MyKinley 2013, 150-151.

259 НАCK 2002, 131.

260 Claus Dobiat points out that such rings frequently occur in similar amount in graves of the Sulmtal cemetery. Dobiat 1980, 145. 
Iron rings of such dimensions are tend to be percieved as parts of horse harness, however, various other functions are also presumable, for instance that they were part of the attire. ${ }^{261}$ Once again, it should be emphasised that no object could be identified without any shadow of doubt as part of horse harness. There are several examples of grave assemblages in close vicinity of Tihany, comprising iron rings but no horse bit or other parts of harness. ${ }^{262}$ These (or at least some of them), however, might be seen as iron bracelets, which can be obviously ruled out as a possibility in the case of our rings due to their small diameter. Similarly small rings with angular cross-section have been found in context of the grave assembalges of the Győrújbarát I tumulus ${ }^{263}$ and the Vaskeresztes II tumulus, ${ }^{264}$ thus they indicate that these rings could have been part of a horse harness. However, it must be noted that among the metal finds of the Vaskeresztes II tumulus two bronze ring $\mathrm{s}^{265}$ came to light quite similar to the iron pieces under discussion, ${ }^{266}$ according to Mária Fekete and Claus Dobiat they might have been parts of belt garnitures. ${ }^{267}$ It might be noteworthy to mention that from the recently excavated tumulus of Regöly, similar rings have been unearthed, ${ }^{268}$ however, their function is yet highly duobtful.

\subsubsection{Basket-shaped buttons}

The basket-shaped buttons (Fig. 14.2) should also be addressed here, since the similar specimens ${ }^{269}$ that have been found in context of the grave assemblage of the tumulus near Kismezo are considered to be part of the horse harness, or to be more precise, Éva Vadász believes that these buttons could have belonged to the bridle. ${ }^{270}$ We can also read about two similar items in the preliminary report of the excavation of Tumulus I at Nagyberki-Szalacska, however Tibor Kemenczei does not express his opinion about the presumable function of these objects. ${ }^{271}$ Buttons of the same type along with several fragmented metal finds came to light from Tumulus 118 at Százhalombatta. ${ }^{272}$ Unfortunately, Carola Metzner-Nebelsick does not write about these specimens in her fundamental monography while classifying the bridle ornaments of the Early Iron Age Southern Pannonia, but she agrees with Éva Vadász's opinion, that the cross-shaped button also found in the Kismezö tumulus should be taken into account as an adornment of the bridle. ${ }^{273}$ Mária Fekete also assignes this type to horse harness when she writes about the specimen found in the Vaskeresztes I tumulus. Hence it seems to be conceivable that the specimens found under the Tihany tumulus might also have been part of a horse harness. Here, I would like to present three further instances that support this

261 Dobiat 1980, 145; Rebay 2006, 161.

262 For instance: Nagydém-Középrépáspuszta - Grave 1: NAGY 1939, 39; Grave 19: ibid. 42; Halimba - Grave 1: LeNGYel 1959, 159; Grave 6: ibid. 159; Grave 36: ibid. 163.

263 Two of them have hexagonal cross-section similarly to the pieces from the Tihany tumulus. FigLER $2010,16$.

264 FeKete 1985, 52.

265 Similar pieces can be recognised in the grave assemblage of the Vaszar 7 tumulus. Mithay $1980,61$. A quite similar specimen has been found in Tumulus 177 of the cemetery at Sopron-Burgstall; Erzsébet Patek supposes that it could have been a part of the string of beads found in the tumulus too. PATEK 1991, 295. The grave assemblage of Tumulus 2 near Janíky also included an analogous specimen. STUDENIKová 1995, Obr. 16.6 .

266 FeKeTE 1985, Abb. 23.31-32.

267 Dobiat 1980, 145; FeKete 1985, 68.

268 Szabó - Fekete 2014, 20; Tab. 127.10,23.

269 VADÁsz 1997, Abb. 2.

270 VADÁsz 1997, 29.

271 Kemenczei 1974, Abb. 6.7-8.

272 Holport 1985, Fig. 5.1-4.

273 MetZner-Nebelsick 2002, 331. 
assumption. To begin with, fifteen such buttons have been unearthed from Tumulus $\mathrm{K}$ of the Frög cemetery and interpreted as adornments of the harness. ${ }^{274}$ Secondly, similar items have been unearthed from a really exceptional grave of the Salzburg-Maxglan cemetery (Grave 400); these buttons are also considered to be parts of the horse harness. ${ }^{275}$ Finally, Grave 52 and Grave 61 of the late Hallstatt cemetery of Szentlörinc comprises an entire harness assemblage that also includes a set of basket-shaped buttons. ${ }^{276}$ The 'Hlásnica' mound in Bohemia near Horákov might be taken into consideration as an interesting example. In the discovered grave assemblage bucket-shape buttons and rings appear together in one context, ${ }^{277}$ although, their presumable function is not touched upon. ${ }^{278}$ The mentioned rings with regard to their shape are similar to the specimens found in the Tihany tumulus, although, they are made of iron. This, however, might provide reason to think that a horse harness consisting of similar elements could have been part of the grave assemblage of the Tihany tumulus' grave. One should bear in mind nevertheless, that the possibility according to which these buttons might have belonged to the costume of the deceased should not be ruled out. ${ }^{279}$

\subsubsection{Small bronze rings / links of chain}

Let us now discuss the small bronze rings (Fig. 14.3). Their diameter seldom exceeds 8 milimeters. Similar rings melted together have been discovered in Grave $9^{280}$ and Grave $21^{281}$ of Halimba, however, contrary to the Tihany tumulus only a small amount of such rings is present in these graves. Hence, Tumulus 6 of Vaszar-Pörösrét seems to be a better analogy, since among the grave goods 59 rings were detectable. ${ }^{282}$ Tumulus 7 of the same cemetery also yielded similar bronze rings, ${ }^{283}$ and some rings have been discovered in Tumulus $11 .{ }^{284} \mathrm{~A}$ chain formed by five such rings has been discovered during the excavation of the Vaskeresztes I tumulus. ${ }^{285}$ This type of bronze rings frequently occurred in the graves of the Statzendorf cemetery. ${ }^{286}$ According to Katharina C. Rebay their function is questionable, but most probably they were adornments of attire. ${ }^{287}$ Sebastian Müller argues with this opinion claiming that the small bronze rings could have been costume decorations. ${ }^{288}$

\subsubsection{Fragmented coils of bronze wire}

As for the coils made of bronze wire (Fig. 14.4). They are not uncommon occurence among the grave assemblages of the Early Iron Age burials in Transdanubia. ${ }^{289}$ Also, they can be found in

274 Tomedi 1994, 373.

275 Moosleitner 1996, 324.

276 JEREM 1968, Fig. 26.52/4.

277 Stegmann-RajtÁr 1992a, Taf. 19.8-17.

278 Stegmann-Rajtár 1992a, 16.

279 Rebay 2006, 179. A similar basket-shaped button has been discovered during the excavation of the pre-scythian Grave 1 of Dédestapolcsány. Farkas Márton Tóth suggests in the publication of the burials that this item should be taken into account as a button, i.e. part of the clothing. Tóтн 2012, 70.

280 LENGYEL 1959, 160.

281 LENGYEL 1959, 161.

282 Mithay 1980, 61.

283 Mithay 1980, 64.

284 Mithay 1980, 64.

285 Fekete 1985, Abb. 11.13.

286 ReBAy 2006, 178.

287 ReBAy 2006, 178.

288 MÜLlER 2012b, 220.

289 For instance Halimba - Grave 9: Lengyel 1959, 160; Vaszar 6: PATEK 1993, Abb. 83.7; Vaszar 11: Mithay 1980, 64. 
tumuli and graves of the Slovakian Plain. ${ }^{290}$ Their function is uncertain.

\subsubsection{Melted bronze fragments attached to calcined bones}

Briefly I would like to touch upon the two melted bronze fragments attached to calcined bones (Fig. 14.5). They seem to indicate that the bronze objects had been placed next to or onto the deceased before the cremation. ${ }^{291}$ Hence, it might be reasonable to belive that the metals of the tumulus' grave assemblage consist (at least partly) of costume decoration.

\subsection{Remarks on the chronology of the tumulus}

Uzsoki published only a few preliminary reports about the tumulus, in which, however, he expresses his opinion about the chronological position differently. Firstly, in the documentation of the excavation as well as in the first preliminary report he writes that the date of the finds is the Ha C phase, ${ }^{292}$ on the other hand, in the most accessible report of the excavation (published in 1984) a different date appears - the Ha B phase. ${ }^{293}$ In the followings, I would like to endeavour to resolve this confusion.

Unfortunately, the grave goods lack finds with considerable dating value, the metal finds are scarce and in fundamentally fragmentary state. However, there are identifiable types among the metal items, one of them is the basket-shaped buttons, although they cannot be much of help, since they seem to have been in use from the early $\mathrm{Ha} C$ phase to the transitional period between the Late Hallstatt and Early La Tène Ages.

This is rather problematic, since the pottery tradition of the eastern Hallstatt circle and especially of Transdanubia lacks vessels with rich decoration and great dating value. ${ }^{294}$ Furthermore, the Hallstatt Age of Transdanubia in fact lacks systematically examined and excavated extensive cemeteries with great sequences of graves and finds enabling us to ascertain accurate chronological relations in a certain region. ${ }^{295}$ Such cemeteries are present quite distant from Tihany, thus there is a limited opportunity to use them while ascertaining the chronological position of the tumulus under discussion. ${ }^{296}$

Let us now discuss the vessels found in the mound. Due to the general and continuous presence of the Kegelhalsgefäße in graves from the late Urnfield phase and during the Early Iron Age, they are very useful from a typochronological point of view in the case of extensive cemeteries. ${ }^{297}$ However, under the Tihany tumulus fragments of only one specimen have been found. Its decoration is rather frequent on the vessels of the Ha C2 phase, ${ }^{298}$ although, there is reason to think that it appears already during the Ha C1 phase. ${ }^{299}$ In the case of the big

290 For instance Nové Zámky Grave 14. Stegmann-RajtÁr 2009, 65. Janíky tumulus 2. StudeníkovÁ 1995, Obr. 16.5. Chotín Grave 131: DušEK 1966, 53. Grave 160: DušEK 1966, 56.

291 FEKETE 1985, 54; НАCK 2002, 140.

292 Uzsoki 1971a, 17.

293 Uzsoki 1986, 248.

294 VADÁsz 1986b, 252.

295 Dobiat 1980; Eibner-Persy 1980; Patek 1982a; Rebay 2006.

296 ReBAy 2006, 274.

297 Dobiat 1980, 70-71; Patek 1982a, 162; PArzinger - Stegmann-Rajtár 1988, 168; Kramer 1996, 210, StegMANN-RAJTÁR 1992b, 143.

298 VADÁsz 1983, 46.

299 For instance the vessels from the tumulus near Kismező: VADÁsz 1997, 31. 
bowls with one handle, it is worth mentioning that the specimens found in the tumuli of Somlóvásárhely and Vaszar bear a decoration consisting of vertical fluted lines considered to be archaic. ${ }^{300}$ The specimens that came to light from the Tihany tumulus are dissimilar to them; they display decoration comparable with the V05 vessel, and as a result, it is reasonable to link them to the Ha C2 phase. ${ }^{301}$ Among the bowls, due to its form the V03 vessel is considered to be exceptional, one of its closest parallels was found in the Grellwald 34 tumulus that belongs to the $3^{\text {rd }}$ phase of the Sulmtal cemetery. ${ }^{302}$ On the other hand, the vessel's horn-handle seems to be a very valuable feature, since this kind of handle with ansa lunata can be cearly linked to the Ha C2-D1 phases. ${ }^{303}$

Ceramic situlae in Central Europe appear at the beginning of the Hallstatt Age. ${ }^{304}$ Characteristic feature of the early examples are the gentle lined profile and the slightly outcurving rim; ${ }^{305}$ this suggests that the specimen from Tihany might be also an early variant. The best analogy of the vessel came to light from Tumulus 83 of the Sopron-Burgstall cemetery that belongs to the $2^{\text {nd }}$ phase of the cemetery. ${ }^{306}$ Situlae with similar shape have been found in Tumulus 2,4 and 6 at Nové Kosariška. ${ }^{307}$ These suggest that ceramic situlae with shape similar to the V06 specimen are present during the Ha C1-D1 phases.

From a chronological point of view, the V09 vessel is considered to be one of the most valuable among the finds of the tumulus. Its closest analogy, the specimen found in the Vaskeresztes 2 tumulus indicates a dating to the end of the Ha C2 phase ${ }^{308}$ However, based on the vessels of this type found in the Kröllkogel, it is presumable that such handled cups were present during the Ha D1 phase, too. ${ }^{309}$ The dating of the vessel to the Ha C2-D1 phases is also supported by the specimens found in Tumulus 114 of Százhalombatta ${ }^{310}$ and Grave 2/92 of the cemetery at Leibnitz-Altenmarkt. ${ }^{311}$ The hF23-hF24 handle fragments have analogies chiefly from the territory of Slovenia; they resemble a handle type that is dated from the Stična-Novo mesto I horizon. ${ }^{312}$ The F48 fragment is also worth mentioning. In Transdanubia vessels bearing animal figures as decoration are generally dated from the end of the Ha C period. ${ }^{313}$ The closest analogies of the F48 fragment came to light from Tumulus 2 of Somlóvásárhely ${ }^{314}$ and from the tumulus near Mesteri ${ }^{315}$ which seems to support the aforementioned statement. However,

300 Metzner-Nebelsick 2002, 155; Lippert 2008, 89. This assumption is also supported by the Ha C1 dating of the Somlóvásárhely tumulus: PARE 1992, ; EGG 1996b.

301 VAdÁsz 1983, 46; MEtZner-Neblsick 2002, 122.

302 Dobiat 1980, 170.

303 TANKó 2005, 154. This dating is also supported by similar handles found near Letenye: HoRvÁTH 2012, 128; and from Grave 3 at Keszthely-Fenékpuszta: HoRvÁtH 2014, 71.

304 Nebelsick 1997a, 71; Hack 2002, 134; Preinfalk 2003, 59.

305 Nebelsick 1997a, 71.

306 Patek 1982b, Fig. 10.15; ibid. Tab.1.

307 Pichlerová 1969, Taf. 11.6-8; ibid. Taf. 21.1-2; ibid. 33.4-5. These tumuli can be dated from the late Ha C1 phase (Tumulus 2) to the end of the Ha C2 phase (Tumulus 4 and 6): Müller 2012a, 344.

308 FEKETE 1985, 76.

309 EGG - KRAMER 2013, 392.

310 Holport 1985, 34; Holport 1986, 95.

311 HAMPEL 2005, 244.

312 The fragments could be assigned to Janez Dular's Type 4: Dular 1982, 79-80.

313 PATeK 1982/83, 68.

314 Contrary to Tumulus 1 of Somlóvásárhely, this mound is harder to date, despite this, it is very likely that it can be linked to the Ha C2 phase: TeržAn 1990, 165; Stegmann-Rajtár 1992b, 100.

315 Based on the metal finds of the mound Éva Vadász suggests a dating to the end of the Ha C: VADÁsz 1996/97, 34 
some believe that the similar animal figures found in Croatia should be dated from the end of the Urnfield period. ${ }^{316}$ On the other hand, the specimens from the Sulmtal cemetery also suggest a dating to the Ha C2-D1 phases. ${ }^{317}$ If we are right to assume that the F49 fragment once belonged to a pedestal with openwork decoration, it also might suggest a similar dating. ${ }^{318}$

The burial form is also important. In the case of the Sulmtal cemetery Claus Dobiat states that the Brandflächengräber are typical during the late phases of the cemetery. ${ }^{319}$ This has been supported by the Wiesenkaisertumulus $4^{320}$ as well as - if we consider a wider region - Tumulus 106 at Saazkogel. ${ }^{321}$ In addition, Tumulus 2 of Zalaszántó represents a grave whose burial form seems to be comparable with the Tihany tumulus, and can be dated to the transition of the $\mathrm{Ha} \mathrm{C}$ and $\mathrm{D}$ periods. ${ }^{322}$

Another aspect one should bear in mind is that neither of the tumuli hitherto investigated around the Somló and Ság Hills, near Nagyberki, Százhalombatta, ${ }^{323}$ Vaskeresztes $^{324}$ and $\operatorname{Vaszar}^{325}$ could be dated after the Ha D1 phase. Moreover, it has been proposed several times that this statement applies for entire Transdanubia. ${ }^{326}$

To sum up, it is thus reasonable to believe that the Tihany tumulus can be linked to the Ha C2 and Ha D1 phases, however we should bear in mind that based on the ceramic material the chronological position of the tumulus could only be ascertained in broad terms.

\subsection{Concluding remarks regarding the tumulus}

The main aim of this paper was the description of the finds, however, considering the hitherto published to some extent dubious, partly questionable information regarding the burial form and the grave itself, it seemed reasonable to evaluate the available documentation of the excavation as well. Firstly, it can be concluded that the assemblage found under the tumulus consisted chiefly of pottery sherds, a characteristic feature that resembles the typical funerary customs appearing in context of the tumuli in the North-Eastern pre-Alpine regions. ${ }^{327}$ There are comparable examples from Transdanubia and the Sulmtal group, although this custom seems to be in strong contrast to the observed customs of the mounds at Nagyberki-Szalacska. ${ }^{328}$ It is also worth mentioning, however, that according to Uzsoki's notes, a considerable

316 Vidović 2003, 84; ŠimeK 2007, 136; Potrebica 2012, 10.

317 Dobiat 1980, 93; HANSEN 2007, 200.

318 Similar pedestal bowls have been dated in case of Nové Kosariška to the Ha C2 phase: MüLLER 2012a; and the specimens found in Tumulus 215 of the Sopron-Burgtall cemetery can be linked to the late phase of the burials: PAtek 1982a, 165. This phase seem to be parallel with the beginning of the Ha D: ibid. 168; PATEK 1982b, Tab. 1. It must be mentioned, however, that among the vessels of Tumulus 83 a pedestal bowl with similar decoration was also present, and this is linked to the early phases of the cemetery: PATEK 1982b, Tab. 1.

319 DoBiat 1980, 170.

320 Tomedi 1992, 212; HACK 2002, 140.

321 LiPPERT 2008, 88-89. This tumulus is parallel with the transition of the $2^{\text {nd }}$ and $3^{\text {rd }}$ phases of the Sulmtal cemetery.

322 PAтEK 1974/75, 207.

323 Holport 1985, 34.

324 It must be noted that the Schandorf-Vaskeresztes cemetery comprises at least of 5 tumulus-groups, and only three mounds have been excavated yet. SAUER 2015, 58-59

325 PATEK 1982a, 167; TERŽAN 1990, 166.

326 Stegmann-Rajtár 1992b, 107; TerŽAn 1998, 519; VAdÁsz 2003, 95. EgG - Kramer 2013, 473.

327 Pittioni 1954, 587; Egg 1996a, 58.

328 In Tibor Kemenczei's view, among the grave goods of the tumuli at Szalacska, contrary to the metal finds, potteries played a secondary role. Kemenczei 1974, 11. 
amount of bronze and partly iron fragments has been discovered. ${ }^{329}$ Due to their extensively fragmentary state, it is nearly impossible to evaluate them.

As it proved to be presumable earlier, despite their partly deficient and fragmentary state, the ceramics found under the tumulus do not rule out the possibility that an actual burial has been found. The interpretation occurring most in the literature regarding the fragmentary potteries links them to the funeral rite, to a possible funeral banquet, suggesting that these vessels were broken to pieces during such events. ${ }^{330}$ This might be also supported by the considerable amount of animal bones also found in the mound. ${ }^{331}$ On the other hand, it is worth questioning whether the vessels could be taken into account as pyre goods as there is reason to believe that the vessels had been placed onto the pyre. ${ }^{332}$ And it is also likely that they were already in pieces at that time. As a result, the vessel set could be only precautiously and with proviso compared to the grave goods of any other Hallstatt Age tumulus. ${ }^{333}$ In this regard, special attention should be paid to the tumuli of Nagyberki-Szalacska and Vaszar-Pörösrét in the future, whose ceramic sets based on the preliminary reports seem to be similarly fragmentary as in the case of the Tihany tumulus. ${ }^{334}$

On the other hand, it can be said with confidence that in general the ceramic assemblage of the Tihany tumulus is comparable with the vessel sets found in the burial mounds around the Ság Hill, especially the Kismező tumulus, ${ }^{335}$ as well as near the Somló Hill. In addition, it should be admitted that the vessel types present in the case of the Tihany mound generally occur in the vessel sets of the burial mounds of Transdanubia and even of the eastern Hallstatt circle. Contrary to the similarity between the assemblages found in the tumuli in Veszprém County from a typological point of view, due to the presumably intentionally fragmentary state of the vessels of the Tihany tumulus, the differences regarding the funerary customs might be emphasised as well. Another fact supporting this idea is that, contrary to the burial mound under discussion, among the grave goods of the aforementioned tumuli near the Ság and Somló Hills metal artefacts e.g. weapons and horse bits play a significant role. ${ }^{336}$ These objects could be personal belongings of the deceased, ${ }^{337}$ which is less probable in the case of the ceramics of the Tihany tumulus. On the other hand, this personal character of these objects - linked chiefly to male burials ${ }^{338}$ - is partly suggested by the fact that these had been placed next to the deceased before the cremation, ${ }^{339}$ which is quite similar to what has been supposed in the case of the Tihany tumulus' vessels, hence the term pyre goods was used.

329 It is rather confusing that contrary to Uzsoki's description only a small amount of metal finds can be found in the Laczkó Dezső Museum's inventory.

330 Nebelsick 2000, 221; Bernhard - Weihs 2003, 94; Lippert 2008, 89; Potrebica 2012, 20.

331 BERTHOLD 1998, 41-42.

332 McKinley 1994, 133; McKinley 1997, 130; McKinley 2013, 150-151.

333 Unfortunately, in the $19^{\text {th }}$ and in the first part of the $20^{\text {th }}$ centuries excavations of tumuli did not tend to be careful with ceramics, as a result, in most cases the grave goods of Transdanubia's tumuli must be considered deficient.

334 However, it should also be mentioned that here the ceramic grave goods of the burial mounds at Nagyberki seem to have played a secondary role compared to the metal artifacts. KEMENCZEI 1974, 11.

335 It is somewhat questionable, to what extent the vessels could be found in this chamber linked to one burial, since the divided structure of the chamber presupposes the possibility of at least two burials within. LÁzÁR 1951, Tab. 22.1.

336 NeBELSick 1994, 335; VADÁsz 1996/97, 29; VADÁsz 1997, 27.

337 MetZner-NeBelsick 1997, 94.

338 TERŽAN 1986, 234; KeLler 2015, 166.

339 FeKete 1985, 54; Dobiat 1980, 50. 
I have already dealt with the question raised by Uzsoki's interpretation. There is no possibility to evaluate the ceramics in order to define a detailed chronological sequence of the pyre that could be seen as an evidence for the multiple use of the place for cremation, in this regard, unfortunately, the metal finds cannot be any help either. In my view, however, it is beyond any doubt that under the tumulus the actual place of a funerary pyre has been found. Based on chronological position, the fragmentary state of the ceramic assembledge, etc. among the burial mounds including the funeral pyre the Wiesenkaisertumulus 4 can be most successfully compared to the Tihany tumulus, which leads us to believe that the latter one could also be seen as a Bustumgrab. However, there is also a significant difference between the funerary customs considering the position of the human remains. Contrary to the Tihany tumulus, in the case of the Wiesenkaisertumulus 4 the calcined bones were carefully collected from the pyre remains and deposited into an urn, a bronze Kreuzattaschenbecken. ${ }^{340}$

What can be said about the deceased? No anthropological analysis of the remains have been conducted so far, however, based on the finds and other features of the burial, some assumption could be made that might be compared to the future results of the analysis. To begin with, Biba Teržan believes that the Brandflächengräb burial form can chiefly be linked to graves of women. ${ }^{341}$ In the case of the Tihany tumulus a spindle-whorl might also suggest that the buried deceased was female. ${ }^{342}$ Furthermore, despite the entirely fragmentary state of the metal finds it seems to be sure that among the discovered objects no weapon is present, which might be seen as an indirect evidence suggesting that the burial of a woman has been excavated.

\section{Stone-lined grave}

\subsection{The discovery of the grave}

Excavations proceeded at the site in the autumn of 1971. This time the main interest of the investigations was the tumulus with the sunk-in top as it was earlier referred to. Following the last year's practice the reference point remained to be the electricity pylon, which stood next to Tumulus 1 and, unfortunately, was removed during the subsequent construction works. It is also problematic that set aside two drawings of the profile of Tumulus 2 and Uzsoki's notes, neither a plan nor other documentation remain to be found in the museum that could help defining the locations of the different features found during the excavation.

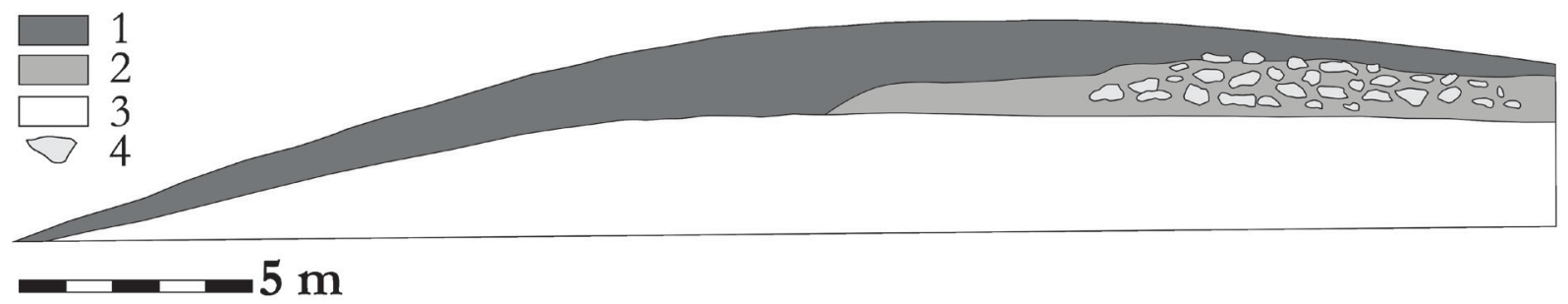

Fig. 15. Profile 1. 1 - Greyish-brown mixed layer, 2 - Dark grey layer, 3 - Yellow subsoil, 4 - Limestone blocks.

340 HАCK 2002, 98.

341 In case of the region of Slovenian Styria: TeRžAn 1990, 57. In case of Styria in Austria: TERŽAN 1990, 128-129.

342 KeLLer 2015, 165. 


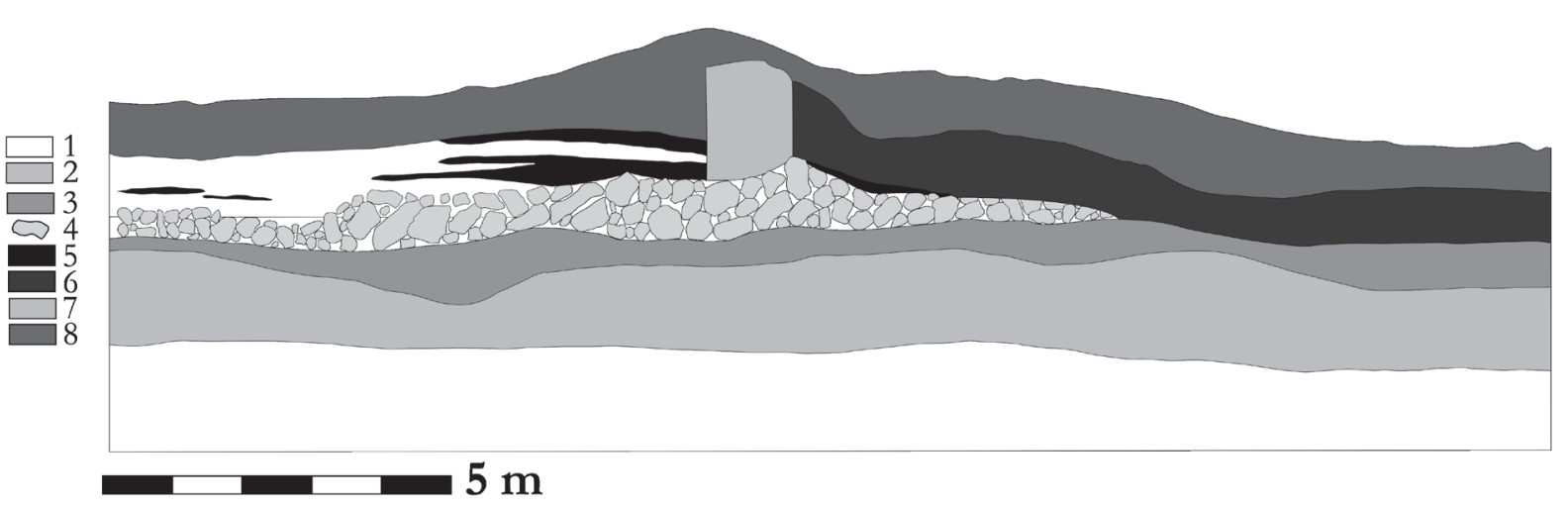

Fig. 16. Profile 2. 1 - Yellow subsoil, 2 - Brown mixed layer, 3 - Yellow layer mixed with gravel, 4 - Limestone blocks, 5 - Greyish-black layer, 6 - Dark grey layer, 7 - Disturbed part, 8 - Brown soil.

The works started on October $7^{\text {th }}$, and the stone heap inside the tumulus was hit by October $13^{\text {th }}$ at a point located $10 \mathrm{~m}$ to south and $2.5 \mathrm{~m}$ to west of the pylon. One of the drawings showing the cross-section and the stone heap inside the tumulus was made two days later, but I could not find any exact reference suggesting where this profile was drawn. I just assume that somewhere southwest of the pylon in a SW-NE direction. On November $9^{\text {th }}$ the machines reached a disturbed part of the structure, a deep shaft dug into the tumulus. According to Uzsoki's notes this should have been located some $8 \mathrm{~m}$ to northwest of the reference point. It may not be surprising that this shaft appears in the section just when the excavator reached the edge of the sunk-in part of the tumulus. On the other hand, it bears significance that the stones are missing under this part of the barrow. It might be a robbing shaft or, and this seems to be more probable, it could be the trench opened by Viktor Récsey during his investigations of the tumuli I mentioned earlier.

The works paused for December, and continued in the middle of January. By that time it was obvious that the shaft was an intentionally dug trench aiming for the centre of the tumulus. As they were reaching the northern part of the tumulus, remains of the stone heap reappeared, and here another drawing of the cross-section was made. In this case the notes contain enough information to enable us to place this drawing, but unfortunately the dimensions and exact location of the tumulus still remains unknown.

Just like during the excavation of Tumulus 1 , several modern age burials have been unearthed. ${ }^{343}$ These, however, are less exciting than the skeletons found in a layer under the fill of the tumulus. In Uzsoki's notes and report he writes about three bee-hive-shaped pits containing the remains of several individuals. ${ }^{344}$ It is rather unfortunate that I did not manage to find any documentation of these graves apart from his notes, mainly because Uzsoki was not always present while they were unearthed. The finds in the museum allow a vague dating to the beginning of the Late Bronze Age. ${ }^{345}$ In context of this paper I will not address these graves in detail.

343 Récsey also reported about graves he dated to the $18^{\text {th }}$ and $19^{\text {th }}$ centuries. He found these during the excavation he conducted in the early 1890s, which might also suggest that the trench observed by Uzsoki might be identical with the one Récsey opened nearly a century ago.

344 Uzsoki 1971b, 22; Uzsoki 1986, 249.

345 During the most recent excavation in Óvár one pit was identified containing material of the late Tumulus culture, (REgenye 2004, 190; MARTON - REgenye 2005, 50) however, an earlier settlement phase of the site is also conceivable. BónA 1975, 198; KISS 2012, 304. 


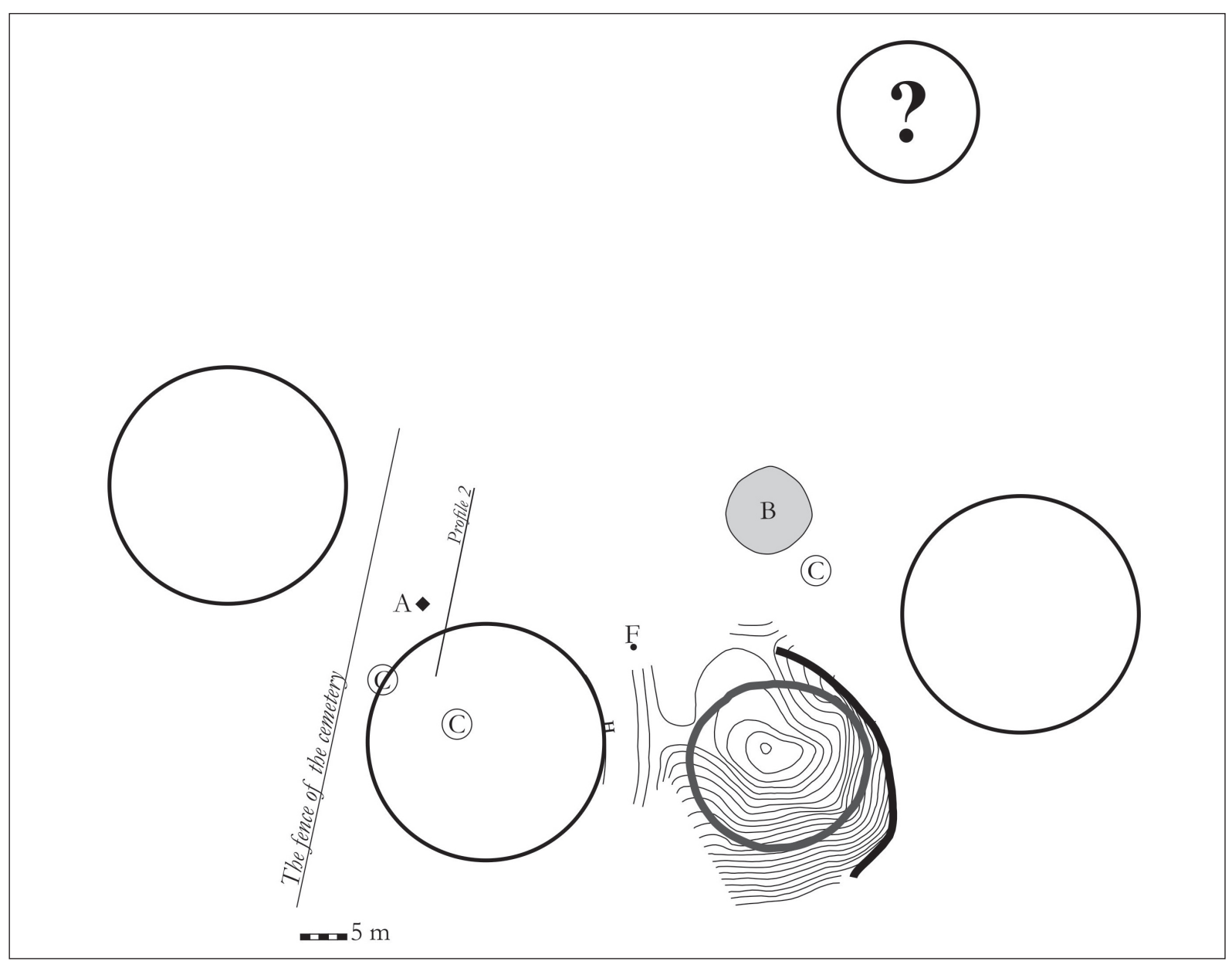

Fig. 17. Plan of the site. A - The stone-lined grave, B - The third tumulus, C - Late Bronze Age pits with human remains, $\mathrm{F}$ - Reference point, $\mathrm{H}$ - The border of the area covered with stones under Tumulus 2.

The Early Iron Age burial was discovered on March $1^{\text {st }}$. Due to the fact that no plans are available, its location can be only ascertained in relation to Tumulus 1 (Fig. 17). According to Uzsoki the area surrounding the grave was covered by stone blocks, which raises the question whether this feature is identical with the one depicted on Section Plan 2. Presumably, this section was cleared some $2.5 \mathrm{~m}$ to southeast of the stone-lined grave. As for the structure of this stone heap, Uzsoki remarks that it was similar to the feature identified in the "Early Iron Age tumulus", presumably Tumulus 1, since earlier he made the same comparison in the case of the stone blocks found in Tumulus 2 in late 1971. With regard to the latter, however, he raised attention that the structure is due to the loosely scattered stones dissimilar to the stone heap found in Tumulus 1. Hence, the stone packing depicted on Section Plan 2 might be interpreted as a new feature, since it seems as massive as the one in Tumulus 1, although, its dimension is more modest. On March $1^{\text {st }}$ Uzsoki wrote, to northeast we reached a stone packing observable on an area of several meters. This is the one covering the stone-lined grave, unfortunately, he does not mention anything with regard to its relation to the stones discovered earlier. However, it seems certain that in the documentation and later reports the grave is thought to be independent from Tumulus $2,^{346}$ whose burial has not been found, probably because it was destroyed by the shaft identified in the central part of the barrow. 


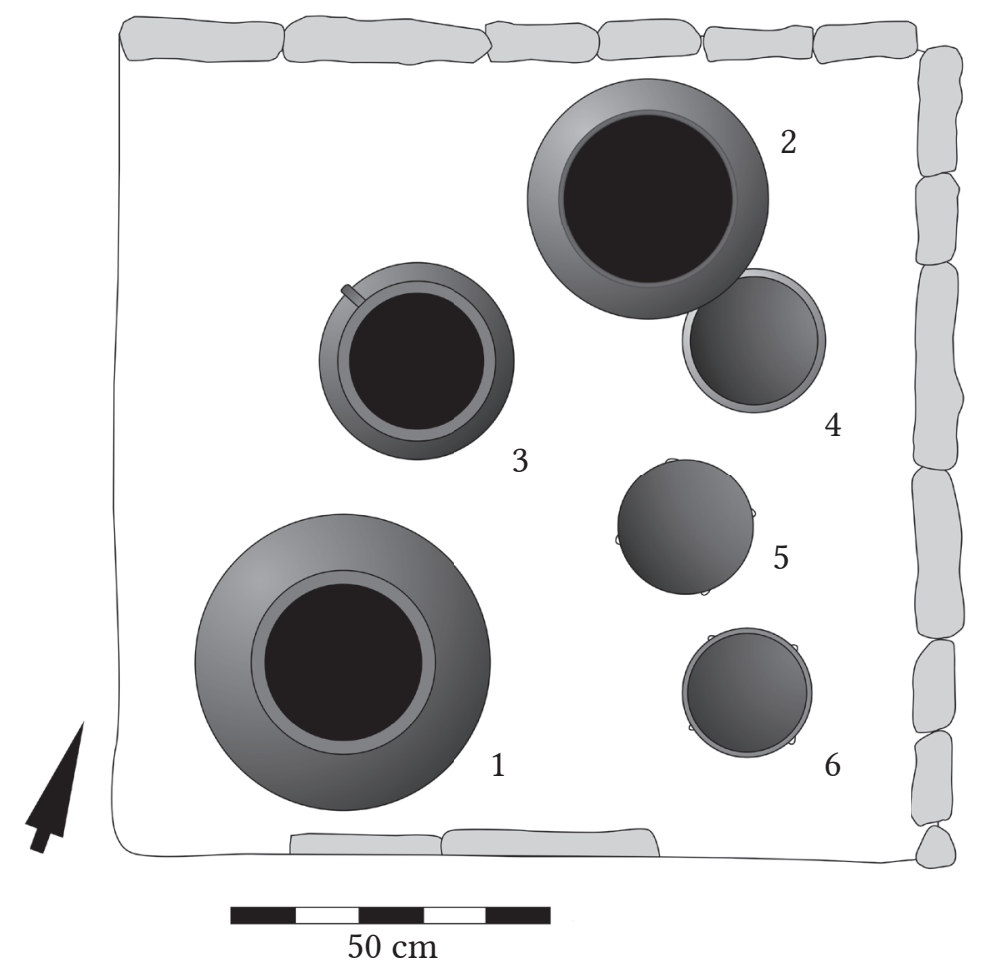

Fig. 18. Plan of the stone-lined grave after Uzsoki's drawing.

Description:

- Grave: $1 \mathrm{~m}$ long and $1.1 \mathrm{~m}$ wide, almost square, covered by a stone heap, its relative depth is unknown. From three sides it is surrounded by vertically placed stone slabs. There are no stone blocks between the potteries, suggesting that originally the grave could have had a certain kind of chamber.

- Type: Cremation burial in urn

- Grave goods: Six vessels have been unearthed, their arrangement is presented by Fig. 18.

\subsection{Vessels from the grave (Fig. 32)}

\subsubsection{Vessel with conical neck (G1)}

The stone-lined grave yielded only one specimen of the type. Its basic features concerning shape and decoration appear already in the late Urnfield period. ${ }^{347}$ Recently, several grave finds from the vicinity of Keszthely have been published. Unfortunately, the potteries are fragmentary in general, similar shapes might be observed nevertheless. ${ }^{348}$ The complete vessel from Hévíz-Egregy might be considered to be an exception. ${ }^{349}$ Due to its neck's shape and the knobs decorating it above the shoulder it can be compared with the vessel from the grave under discussion. Based on typological considerations, László Horváth dated the vessel to the Ha

347 PATEK 1968, 95; Kőszegi 1988, 56; Lochner 1991, 299.

348 For instance the lower part of a Kegelhalsgefäß type vessel from the Keszthely-Vadaskert cemetery, (HoRvÁth 2014, Fig. 8.6) dated to the Ha C period. HoRvÁth 2014, 66.

349 Horváth 2014, Fig. 2.1. 
C1 phase. ${ }^{350}$ However, this vessel does not show the somewhat sharply profiled shoulder-belly line that the G1 vessel does. This feature might be observed on the vessel assigned to the same type from Szigetszentmárton, and the knobs decorating the vessel represent a further similarity. ${ }^{351}$ This specimen came to light from a grave dated parallel with the occurence of the Scythian-type finds in Eastern Hungary. ${ }^{352}$ On the other hand, vessels with marked shoulder-belly line also appear in late Urnfield period contexts, as it is clearly indicated by the specimen from the Szombathely-Zanat cemetery dated to the Ha B1-B3 phases, ${ }^{353}$ or by several vessels from North-Eastern Slovenia. ${ }^{354}$ According to Biba Teržan these vessels represent a widely spread type in the South-Eastern pre-Alpine region during the Ha B3 phase. ${ }^{355}$ In addition, there are several specimens from Transdanubia suggesting that the characteristic features of the G1 vessel already appeared during the late Urnfield period. Among them the vessels from Mozsgó, ${ }^{356}$ Szentendre-Szigetmonostor ${ }^{357}$ and Csönge. ${ }^{358}$ It should be emphasised that these vessels are highlighted as early representatives of the so-called 'hallstattisation' of the vessels of late Urnfield period cemeteries. ${ }^{359}$

Grave 29 of the Dalj Busija cemetery also yielded a comparable vessel that based on its context might be dated to the early Hallstatt period. ${ }^{360}$ Similar dating has been ascertained in the case of a similar vessel unearthed in the cemetery near Wildon. ${ }^{361}$ Claus Dobiat distinguished five types of vessels with conical neck from the Sulmtal cemetery. ${ }^{362}$ Among these particularly the representatives of Type 1 could be closely linked to the G1 vessel. This variant was also present since the final part of the Urnfield period. ${ }^{363}$ Due to the very fact that in the case of Tihany only two instances are known of the Kegelhalsgefäß type it is hardly possible to ascertain a similar chronological trend like in the case of the Sulmtal cemetery. ${ }^{364}$ However, we might take into account Dobiat's observation, according to which the vessels of this variant were getting more sharply profiled with time. ${ }^{365}$

As for the close vicinity of the site, two comparable examples from the Halimba cemetery might be enumerated. ${ }^{366}$ In spite of its smaller size the vessel from Grave 33/34 deserves attention due to its similar shape and decoration. It also bears significance since in Carola Metzner-Nebelsick's view this specimen could be linked to the earliest phase of the cemetery, ${ }^{367}$ which is usually dated to the Ha C2 phase. ${ }^{368}$ The vessel from the Csönge tumulus

350 HORVÁTH 2014, 66.

351 KeMENCZEi 1977, Abb. 5.1.

352 Kemenczei 1977, 83.

353 IlON ET AL. 2011, Fig. 36.3.

354 For instance TeržAn 1990, Tab. 58.4; Tab. 75.2.

355 TERŽAN 1990, 65.

356 PATEK 1968, Tab. 97.8.

357 Patek 1968, Tab. 123.9,11,12; Tab. 128.12; Tab. 129.9; Nebelsick 1994, Abb. 10.D.

358 PATEK 1968, Tab. 40.5.

359 NeBELSICK 1994, 327.

360 MetZner-Nebelsick 2002, Taf. 71.1; 136.

361 Kramer 1996, Abb. 7.4.

362 DOBIAT 1980, 68.

363 DoBIAT 1980, 71.

364 DoBiAt 1980, 68-72.

365 DoBiAt 1980, 70.

366 Grave 10: Lengyel 1959, Tab. 35.9; Graves 33/34: Lengyel 1959, Tab. 46.9.

367 MetZner-Nebelsick 2002, 101.

368 Stegmann-Rajtár 1992, 106; Patek 1993, Abb. 34. 
might also be dated to the same phase ${ }^{369}$ its sharply profiled shape and broad neck resemble the vessel under discussion, but its horn-like knobs are presenting a dissimilar feature. A few examples from the Vrádište cemetery are also suggesting that vessels with comparable shape have been made during the second part of the Ha C period, even during the Ha D1 phase. ${ }^{370}$

To sum up, it can be said with some confidence that this vessel can hardly be dated prior to the final phase of the $\mathrm{Ha} \mathrm{B}$ period, ${ }^{371}$ but it cannot be dated precisely within the subsequent periods.

\subsubsection{Large bowl with conical neck (G2)}

A vessel with quite the same shape appears among the potteries of the near Early Iron Age settlement at Balatonboglár. ${ }^{372}$ András Jáky assigns this specimen to the Kegelhalsgefäß type. ${ }^{373}$ There is little doubt that the vessel possesses a conical neck, in this case however, the diameter of its rim is bigger than its height and the diameter of the bottom, a characteristic feature of the bowls. ${ }^{374}$ If we take into consideration the variants of the type defined by Dobiat, the G2 vessel might resemble the examples of Typ 3, though some bowl forms are also seem to be somewhat similar. ${ }^{375}$ It is worth mentioning that the taller, bulgy-shaped specimens are linked to the earlier graves of the cemetery. ${ }^{376}$

The ceramic material of the graves unearthed near Dvorišce has not yet been entirely published, but among the known vessels one appears to be to some extent similar to the G2 vessel, yet considerably smaller ${ }^{377}$ It is interesting that based on this vessel among others Josip Vidović assumes that the cemetery might have been already used during the final phase of the Urnfield period. ${ }^{378}$ The mentioned vessel, however, does not bear a channeled decoration. A vessel from Grave 38 of the Stillfried cemetery among others might also indicate that the type of the G2 vessel has analogies among the ceramic forms of the Urnfield period. ${ }^{379}$

In my view the best analogies of the vessel under discussion have been found during the excavation of Tumulus 1 at Nagyberki-Szalacska. ${ }^{380}$ However, their decoration is considerably dissimilar. As for the vessels from the barrows at Szalacska, we also find a specimen of the socalled Großgefäße mit kurzem Kegelhals type. ${ }^{381}$ Despite the fact that these also have relatively short, conical neck, they are hardly comparable to the G1 vessel, mainly because they tend to be richly decorated and their maximal diameter is considerably higher than in the case of the G2 vessel. Set apart from the examples found near Keszthely and Szalacska, they are chiefly distributed in the region between the Drava and Sava Rivers, and appear in the $7^{\text {th }}$ century BC..$^{382}$

369 LÁzÁr 1955, Tab. 31.3; PATEk 1993, Abb. 95.11.

370 Pichlerová 1960, 146; Pichlerová 1960, Tab. 6.14; Müller 2007, 626.

371 PATEK 1968, 95.

372 JÁKy 2016, Fig. 5.34.

373 ЈÁKY 2016, 157.

374 Dobiat 1980, 77; Rebay 2006, 75.

375 For instance the bowl of the Leitengritschwald 46 tumulus, which also bears an oblique channeled decoration. Dobiat 1980, Taf. 103.10.

376 DOBIAT 1980, 78.

377 Vidović 1990, Abb 5.1.

378 Vidović 1990, 81.

379 Kaus 1984, Taf. 38.g.

380 Kemenczei 1974, Fig. 3.3 (HNM 72.7.17); Fig. 4.1.

381 MetZner-Nebelsick 2002, Abb 40.1.

382 MetZner-Nebelsick 2002, 112. 
As for the G2 vessel's decoration composed of oblique chanelling on the shoulder and belly, it is considered to be characteristic of the Urnfield period even during its final phase as it is suggested by the vessels from Szombathely-Zanat, ${ }^{383}$ Barcs $^{384}$ and Somlóvásárhely. ${ }^{385}$ The latter vessel, a Kegelhalsgefäß, came to light in 1959, presumably from a late Urnfield - early Hallstatt period cemetery south of the Somló Hill. On the other hand, it appears that the same decoration became frequent to some extent during the second part of the Ha C period. ${ }^{386}$ Examples from Slovenia, ${ }^{387}$ Austria ${ }^{388}$ and of course Western Hungary, namely Halimba, ${ }^{389}$ Tatabánya ${ }^{390}$ and Cönge ${ }^{391}$ might be mentioned. It is worth mentioning that the latter example seems to partly resemble the G3 vessel in regard to its shape. From a chronological point of view, this kind of decoration has a very scant value. ${ }^{392}$

\subsubsection{Tall bowl with handle (G3)}

This vessel represents one of the most frequently occurring type in Hallstatt Age burial contexts in Western Hungary. ${ }^{393}$ It might be worth keeping in mind that at least three examples are found among the vessels from Tumulus 1, although, their shape is somewhat dissimilar to the G3 specimen. Frankly, most examples bear a decoration composed of "V"-shaped multiple channelling and knobs on the shoulder of the vessel. In the case of the G3 bowl only the knobs are apparent, and instead of the mentioned pattern the vessel's belly and shoulder bears oblique chanelling quite similar to the G2 bowl's decoration. Furthermore, the characteristic shape of the vessel type is more sharply profiled than the specimen from the stonelined grave. As for the dating of the classical variant they might be linked to the Early and Middle Hallstatt Age according to C. Metzner-Nebelsick. ${ }^{394}$ As it has been mentioned earlier, in É. Vadász' view the pattern observable for instance on the V01 and V02 vessels from the tumulus can be dated to the Ha C2-D1 phases, ${ }^{395}$ however, the example from Somlóvásárhely suggests the possibility of an even earlier occurence of such decoration. ${ }^{396}$

L. Nebelsick raised attention to a similar vessel found in the Szentendre-Szigetmonostor cemetery dated to the Ha A2-B periods. ${ }^{397} \mathrm{He}$ argues that a number of vessels, for example $\mathrm{Ke}$ gelhalsgefäße and the mentioned bowl with handle, represent very early Hallstatt forms in this cemetery. ${ }^{398}$ Interestingly, there is some evidence that these graves were belted by stone circles and were covered by modest mounds. ${ }^{399}$ In this sense, a similar vessel from the Halim-

383 ILON ET AL. 2011, Fig. 19.4; Fig. 22.3; Fig. 49.1-2; Fig. 54.3.

384 Honti 1993, Abb 6.1.

385 BAKAY ET AL. 1970, 209.

386 TERŽAN 1990, 114.

387 TeržAn 1990, Taf. 14.29; Taf. 15.19.

388 Dobiat 1980, Taf. 53.1,6; Taf. 89.2.

389 Lengyel 1959, Tab. 48.4.

390 Groma 2015, Abb. 6.2; Abb. 6.11; Abb. 7.1.

391 LÁzÁr 1955, Tab. 33.6.

392 DULAR 2013, 58.

393 VADÁsz 1983, 46.

394 METZNER-NEBELSICK 2002, 122.

395 VADÁsz 1983, 46.

396 Unpublished, Laczkó Dezső Museum Veszprém, inv. no. 63.25.1. As for the dating of Tumulus 1 at Somlóvásárhely see EGG 1996b.

397 PAtek 1968, Taf. 128.8.

398 NeBELSICK 1994, 327.

399 PATEK 1968, 75. 
ba cemetery, ${ }^{400}$ from the Csönge tumulus ${ }^{401}$ and from Tumulus $1 / 57$ near Hurbanovo ${ }^{402}$ along with the specimen from the stone-lined grave might also represent the early variant of the characteristic Hallstatt-type. Another bowl from the Nagydém-Középrépáspuszta cemetery might be also mentioned here. ${ }^{403}$ Although their shape is quite similar to the G3 vessel, none of them bears similar decoration. There is one instance corresponding to the classical variant, yet with oblique chanelling, from the Tatabánya-Alsó vasútállomás cemetery, nevertheless. ${ }^{404}$ A further vessel found unter the tumulus near Tata might suggest that this variant was still in use during the Ha D1 phase. ${ }^{405}$

\subsubsection{Small bowls}

It has been mentioned earlier that these vessels represent one of the most frequent and widely spread type throughout both the Urnfield as well as the subsequent Hallstatt period. ${ }^{406}$ Thus, it is not surprising that among the vessels of the stone-lined grave we find more than one example, which, however, can be assigned to distinct variants.

\subsubsection{Bowl with inverted and oblique faceted rim (G4)}

If we follow the typological framework elaborated by K. Rebay-Salisbury for the Statzendor cemetery, the vessel could be assigned to the variant defined as Einzugrandschalen mit schräg kanneliertem bzw. facettiertem Rand. Interestingly, similarities between the examples of this type and the G4 vessel are not limited to the decoration, but there are also shared features considering the shape. ${ }^{407}$ As the author notes, the oblique chanelling already appears as a frequent decoration in the early Urnfield period and persists till the Ha D1 phase, but the slanting faceting seems to be characteristic from the early Hallstatt period. ${ }^{408}$ In the case of Lower Austria this tends to be the general opinion, ${ }^{409}$ though, in some cases there is intention to distinguish between chanelling and faceting by the definition of bowls with "real" and "pseudo" turban-shaped rim, respectively. ${ }^{410}$ Truth to be told, the usage of the term "pseudo" turban-shaped rim, seems to be somewhat flexible, however. ${ }^{411}$ In the case of Styria the term is generally used to refer to a decoration on the bowl's rim composed of particularly thin fluted lines that do not reach or deform the rim itself. ${ }^{412} \mathrm{~S}$. Kovačević adds another feature, but basically agrees with the above definition, namely the "pseudo" turban rim is supposed to be composed of shallow chanelling that does not modify the shape of the rim. ${ }^{413} \mathrm{I}$. Hellerschmid argues that the pseudo turban-shaped decoration is composed of slanting faceting or shallow fluting. ${ }^{414}$

400 Lengyel 1959, Tab. 39.6.

401 LÁzÁr 1955, Tab. 33.6.

402 PAulík 1958, Taf. 3.7.

403 NAgy 1939, Taf. 4.11.

404 Groma 2015, Abb 6.11.

405 VadÁsz 2003, Tab. 3.2.

406 Griebl 1997, 41; Hellerschmid 2006, 135; Dular - Tomanič Jevremov 2010, 188.

407 ReBay 2006, 58.

408 ReBay 2006, 58.

409 Griebl 2004, 167; Preinfalk 2012, 72.

410 HeLlerschmid 2006, 140-141.

411 Gutjahr 2015b, 183.

412 Dobiat 1980, 116; Smolník 1994, 47; Tiefengraber 2005, 103-104.

413 KovačEvić 2009, 56.

414 Hellerschimd 2006, 141. 
As for Transdanubia, bowls with turban-shaped rim are thought to be quite common throughout the Urnfield and Ha C periods; it seems to be valid for both faceting as well as slanting cannelures. ${ }^{415}$ The same applies to North-Eastern Slovenia ${ }^{416}$ and the region between the Drava and Sava Rivers. ${ }^{417}$ In the case of the Sulmtal cemetery the bowls decorated with wide, shallow cannelures in fact similar to faceting tend to come from contexts dated to the younger phases of the cemetery. ${ }^{418}$ Bowls with inverted rim and similar decoration found in the tumuli at Sopron-Burgstall are mainy dated to the IIa phase according to A. Eibner-Persy, ${ }^{419}$ albeit the settlement yielded comparable examples that could be dated to the earliest phase of the site. ${ }^{420}$ The Hallstatt period settlement near Letenye is also worth mentioning, because L. Horváth argues that the absence of any kind of the decoration technique under discussion on small bowls suggests a dating of the site to the later phases of the early Iron Age, i.e. further from the Urnfield period in terms of chronology. ${ }^{421}$ Contrary to the Letenye site, however, small bowls with turban-shaped rim do appear in context of the settlement near Balatonboglár dated to the Ha C2-D1 phases. ${ }^{422}$

The best analogy of the G4 vessels in my view is the small bowl found with an iron spearhead presumably in a tumulus near Bakonygyepes. ${ }^{423}$ The specimen is decorated similarly to the G4 vessel, but unfortunately it has very limited dating value.

\subsubsection{Conical bowl with inverted, oblique faceted rim and omphalos (G5)}

Set aside that among the small bowls this specimen seems to be the most delicately shaped, two basic features distinguish it from the G4 vessel. Firstly, the bottom formed with an omphalos, a decorative element that was present throughout both the Urnfield as well as the subsequent Hallstatt period. ${ }^{424}$ In the case of the Sulmtal cemetery such bowls with similarly formed bottom are generally quite frequent. ${ }^{425}$ Hence this feature has scant dating value. Another difference between the two bowls are the four knobs under the rim decorating the vessel under discussion. Bowls with similar knobs tend to be associated with the earlier graves of the Sulmtal cemetery, ${ }^{426}$ but a specimen from Leibnitz-Altenmarkt points to the usage of such vessels during the later phases of the Hallstatt Age. ${ }^{427}$

As for Transdanubia, these features are quite common, though, separately. In the case of the Halimba cemetery two conical bowls might be mentioned that bear knobs similarly to the G5 vessel, ${ }^{428}$ but the omphalos-formed bottom tends to be an often occurring feature of the globular cups. ${ }^{429}$ The slanting faceting decorating the rim is absent similarly to the bowls

415 Patek 1968, 102; Kalicz-Schreiber Et AL. 2010, 253.

416 Dular 2013, 57

417 MetZner-Nebelsick 2002, 135.

418 Dobiat 1980, 116; Tiefengraber 2005, 115.

419 Eibner-Persy 1980, 81.

420 PATEK 1982a, Abb. 25.15-16.

421 HoRvÁth 2012, 125.

422 JÁKY 2016, 155.

423 BAKay ET AL. 1970, Tab. 2.3.

424 Kalicz-Schreiber ET AL. 2010, 253.

425 Dobiat 1980, 116-117.

426 Dobiat 1980, 74.

427 Hampel 2005, Taf. 13.

428 Lengyel 1959, Taf. 36.3,6; PAtek 1993, Abb. 69.15,17.

429 Lengyel 1959, Taf. 31.11,12; Taf 32.6,7; Taf. 34.6; Taf. 35.7; Taf. 39.4; Taf. 40.2; Taf. 43.4; Taf. 45.4; PAtek 1993, Abb 69.14; Abb. 71.11. 
found in the Csönge tumulus and in Tumulus 14 at Vaszar-Pörösrét, but both of them bears an omphalic bottom. Although the latter bears too, its basic shape does not resemble the G5 vessel. ${ }^{430}$ In contrast, the example from Csönge resembles the basic shape. It is worth pointing out that in the case of the vessels found in the Csönge tumulus omphalic bottoms tend to decorate globular cups, like it has been observed in the case of the Halimba cemetery. The tumulus near Kismező is thought to be the oldest Hallstatt period tumulus associated with the Ság Hill; among the vessels discovered in it were three small bowls with inverted rim and conical lower part, both of them have knobs under their rim, but the similarities with the G5 vessel are limited to that. In addition, the same can be said about the small bowl came to light from a tumulus near Felsőnyék. ${ }^{431}$ In fact, small bowls with similar knobs were in use in the Urnfield period in Transdanubia. ${ }^{432}$

The best analogies of the vessel, yet their bottom is not omphalic, are the ones found in the Süttő and Mesteri tumuli, respectively. In the case of Süttő seven bowls were unearthed, these are utterly similar to each other, both bear knobs under the slightly inverted rim decorated with slanting faceting. ${ }^{43}$ The example from the Mesteri mound is also characterised by the same features, however its rim's shape is more inverted than it is on the former instances. Both of them are supposed to be dated to the Ha C2 phase. ${ }^{434}$ Contrary to these examples, due mainly to the fact that other finds are unknown, although allegedly several graves had been unearthed there, the bowl found near Tapolca cannot be dated accurately. ${ }^{435}$ It is really unfortunate given its close similarity to the aforementioned specimens as well as to the example from Tihany, though, it also lacks the omphalic bottom. One vessel from Tumulus 4 at Sopron-Burgstall dated to the IIa phase of the cemetery shows the same features, ${ }^{436}$ hence it also might be taken into consideration as a good analogy of the G5 vessel.

In addition, I would like to raise attention to the pre-Scythian burial assemblages east of the River Danube. Bowls with turban-shaped or slanting faceted, inverted rim are commonly occouring, ${ }^{437}$ and knobs as decorations are not seldom either. ${ }^{438}$ Examples comparable with the specimen from Tihany came to light from Szeged-Algyö ${ }^{439}$ and Füzesabony-Kettős halom. ${ }^{440}$

\subsubsection{Globular variant (G6)}

According to the types distinguished based on the vessels of the Statzendorf cemetery, this bowl might be assigned to the examples labelled as Gedrückte Einzugschale mit kalottenförmigen Unterteil. ${ }^{441}$ Already during the Urnfield period vessels of similar forms were quite frequent. ${ }^{442}$ They have barely any dating value. As it has been mentioned earlier knobs just

430 Patek 1993, Abb 87.9.

431 Wosinszky 1896, Taf. 103.7. Based on a bowl with an ansa lunata-shaped handle the small conical bowl might have come to light from a Ha C2-D1 context.

432 PATEK 1968, Tab. 6.30.

433 VADÁsz 1983, Abb. 15.4-10.

434 VADÁsz 1983, 47; VADÁsz 1996/97, 34.

435 Bakay ET AL. 1966, 162; Taf. 11.13. They date the site to the Late Bronze and Early Iron Age, while E. Patek believes that the graves belong to the Ha A2-B phases. РАTEK 1968, 39.

436 Eibner-Persy 1980, Taf. 3.7.

437 KeMENCZEi 1989, 66.

438 For instance: Mezőcsát-Hörcsögös. PAtek 1993, Abb. 26.16-17; Abb. 28.18.

439 Matuz 2000, Abb. 8.6.

440 Patek 1990, Tab. 6.4.

441 Rebay 2006, 57.

442 Kalicz-Schreiber ET AL. 2010, 252. 
under the rim of the bowls were already frequent during the Urnfield period, and as we have seen several examples can be dated to the Hallstatt period, too.

\subsection{Grave form and burial rite}

To begin with, I would like to address the stones covering the burial, which to some extent raises the question whether it is a tumulus burial. In my view it seems to be certain that Tumulus 2 and the stone-lined grave represent separate burials, even though the grave in the tumulus has not been found. However, both of them along with the example of Tumulus 1 emphasise the importance of using stones with regard to the grave's structure. However, some differences can be recognised. Contrary to Tumulus 1 the stones above the burial seemingly only compose a covering, and not a tumulus. As for Tumulus 2 the stones build a loose packing.

Turning back to the stone-lined grave, it is highly dubious whether it could be considered as a tumulus grave. If it is only about size, it is worth pointing out that in the case of the Zalaszántó cemetery a great variance is observable with regard to the tumuli's dimension. ${ }^{443}$ On the other hand, according to Uzsoki north of Tumulus 1 there was another, third mound, in this case of quite modest dimension. Sadly, its inner structure is entirely unknown; it was destroyed while Uzsoki was not present. But it raises attention to the fact that we might reckon with tumuli of different sizes at this site as well. However, it very well might be that in context of the hillslope the smaller mounds were particularly prone to erosion, and we should also bear in mind that the area was used as a graveyard in the modern ages. ${ }^{444}$ Let us consider the so-called "flat" graves of the region north of Lake Balaton. In the case of Halimba the graves were covered with stones several times suggesting that some kind of superstructure above the burials cannot be ruled out. ${ }^{445}$ Although the graves of the Nagydém-Középrépáspuszta cemetery lack such stone packings, other examples for such structure can be mentioned. ${ }^{446}$ Hence, based merely on analogies and the available documentation of the excavation, it can be hardly decided whether it was a small tumulus or a "flat" grave. Here, I would like to raise attention to the observation made by A. Uzsoki and Gy. Nováki, according to whom there is supposedly a sixth tumulus at the site north of the hitherto excavated one. According to the map they designed it should be relatively small. ${ }^{447}$ Maybe its future investigation will provide an answer for our present question.

Let us move on to the grave form. According to Uzsoki the stone-lined grave might be interpreted as a small burial chamber, possibly built partly of wood. Similar structures have been described in the case of the tumuli at Sopron-Burgstall. ${ }^{448}$ Due to the stone slabs arranged in a nearly square plan the burial chamber of Tumulus 1 at Zalaszántó-Várhely might be taken into account as the best analogy. ${ }^{449}$ Unfortunately, due to previous robbing, the chronological position of this tumulus is doubtful. ${ }^{450}$

443 Havasi - Busznyák 2008, Fig. 12.

444 According to L. D. Nebelsick in fact due to the uncertain circumstances it is pointless to distinguish between small tumuli and simple urn graves at the beginning of the Hallstatt Age. NebeLsick 1997a, 36.

445 Lengyel 1959, 167.

446 Vrádište: MÜLler 2007, 625; Tatabánya-Alsó vasútállomás: GromA 2015, 154.

447 NovÁki - Uzsoki 1999, 66.

448 For instance Patek 1982a, Abb. 11; PAtek 1991, Abb. 2.

449 PATEK 1993, Abb. 67.1.

450 PATEK 1974/75, 206. 
Interestingly, several cases from Styria suggest that graves with nearly regular rectangular plan mainly occur in association with assemblages dated rather to the Hallstatt period than to the previous late Urnfield period. ${ }^{451}$ In addition, in these cemeteries there are several examples of similar stone-lined structures. ${ }^{452}$ During the excavation conducted in 2013 at the Habakuk site two stone-lined graves were discovered, but their exact dating is not yet known. ${ }^{453}$ Vertically placed stone slabs occur in a few tumuli of the Sulmtal cemetery as well. Among them tumuli Leitengritschwald 27 and Grellwald 6 seem to be most successfully comparable with the example from Tihany, because the stones do not entirely enclose the burials. ${ }^{454}$

As for the burial rite, contrary to the tumulus in the case of this grave the calcined human remains were in the G3 vessel and partly in the bowl with conical neck (G2), thus it can be said with confidence that an urn grave has been unearthed. If we take into consideration the "flat" cemeteries of Northern Transdanubia a fairly heterogenic picture becomes apparent. On the one hand, urn graves tend to predominate in the cemeteries of Tatabánya-Dózsakert, ${ }^{455}$ Hegyfalu $^{456}$ and Fertörákos ${ }^{457}$, here the cemetery of Vrádište might be also mentioned. ${ }^{458}$ In contrast, the cemeteries of Nagydém, ${ }^{459}$ Győrszemere ${ }^{460}$ and Tatabánya-Alsó vasútállomás ${ }^{461}$ are characterised by human remains scattered into the grave pit. The graveyard near Halimba has both kinds of cremation burials, and the reason why it deserves special attention is that in three graves the calcined bones have been discovered in deep bowls with handle quite similar to the one filled with cremated remains in the stone-lined grave. ${ }^{462}$ Though, it is not a general phenomenon.

\subsection{Vessel set}

Conspicuously, contrary to the ceramics found under the tumulus the vessels of the stonelined burial were in general presumably intact when they were placed into the grave. This is noteworthy for several reasons. Firstly, it emphasises the differences between the funerary rituals related to the two burials. On the other hand, this presupposes somewhat different funcitions for the vessels. Of course, one functional dissimilarity is that the G3 bowl was used as an urn, which is, as we have seen, relatively common in other cases. In fact, this is the only vessel that bears signs suggesting possible exposure to strong heat. Since these marks of possible secondary burining can only be seen on one side of the vessel, it might be assumed that this side was turned to what possibly might have been the funeral pyre. It is also noteworthy that a number of vessels placed into the grave is significantly lower than the amount identified in the case of Tumulus 1. In fairness, this number rather resembles the amount of grave goods in the case of the Halimba and Nagydém-Középrépáspuszta cemeteries.

451 Karlsdorf: Tiefengraber 2005, 128; Graz-Leechkirche: Lehner 1996, 28; Wildon-Hauptschule: Kramer 2015, 199.

452 Lehner 1996, 28; Kramer 1996, 215; Tiefengraber 2005, 28; Gutjahr 2015a, 428

453 Medarić ET AL. 2016, 79.

454 Dobiat 1980, 56.

455 VAdÁsz 1986a, 219.

456 MolnÁr 2006, 205.

457 Ďurkovič 2009, 65.

458 MÜLLER 2007, 625.

459 Nagy 1939, 50.

460 FigLER 1985, 13.

461 Groma 2015, 156.

462 Grave 7: Lengyel 1959, 160; Grave 10: ibid, 161; Grave 14: ibid, 161. 
According to Uzsoki, they found a fairly decent amount of fragmented animal bones in the G1 vessel. Thus it seems reasonable to believe that it contained food offerings. Vessels with conical neck are chiefly thought to be parts of drinking sets within Hallstatt period graves, ${ }^{463}$ however, one grave of the Halimba cemetery yielded similar food offerings placed into vessels of the Kegelhalsgefä $\beta$ type. ${ }^{464}$ In fact, it seems to be an exception within the cemetery as well as in a broader context, because here and in the case of the Tatabánya-Alsó vasútállomás and Nagydém-Középrépáspuszta ${ }^{465}$ graveyards animal remains were predominantly placed within or around small bowls. Patently, the representatives of this type in the case of Tihany possibly had a different function in context of the grave, though, it has to remain unknown.

What can be said about the assemblage itself? As a rule, the graves of the cemeteries near Nagydém and Halimba are relatively well-comparable with the stone-lined burial in respect of vessel sets. Small bowls if present tend to predominate in each grave, but vessels with conical neck occur more frequently in general. Deep bowls with handle are relatively often associated with sets composed of the two aforementioned. To be more precise, there are 8 graves from both graveyards (50 graves) that possess at least one of each type, i. e. it possesses a set similar to the grave from Tihany. One problematic element is that the G2 vessel does not really have analogies at either site, on the other hand, pots similar to the V07 vessel of the tumulus are the fourth most frequent type among the vessels from Halimba and Nagydém, but none of them appeared among the vessels of the stone-lined burial.

\subsection{Chronology and concluding remarks}

I would like to emphasise that the vessels alone do not allow an accurate dating of the grave. In my view they can be linked to the $\mathrm{Ha} \mathrm{C} 1-\mathrm{C} 2$ phases, but there are other circumstances worth taking into consideration. First of all, the comparison of the vessels found in the tumulus as well as in the grave reveal that the oblique chanelling and faceting, the most characteristic decoration technique for the grave's vessels, is completely absent on the potteries of the tumulus. In contrast, the vessels of the latter frequently show various decorations made with application of graphite, which does not appear in relation to the potteries of the stone-lined burial. Futhermore, typological features that cannot be dated earlier than the Ha C2 phase do not appear among the vessels of the urn grave. I believe that these differences suggest an earlier dating for the burial, however, admittedly these dissimilarities could be linked to a certain social distance between the tumulus and the grave. On the other hand, one has to bear in mind that currently no reliable typochronological framework based on sequences collected from the vicinity of Tihany is at our disposal.

Another aspect is also worth taking into consideration. Excavations on the Óvár site above the tumuli proved that the settlement was already active during the late Urnfield period. ${ }^{466}$ In this sense this site is quite similar to several other significant Hallstatt period settlements

463 RebAy 2002, 98; MÜLLER 2007, 635.

464 Grave 6: Lengyel 1959, 159.

465 NAgy 1939, 50.

466 Regenye 2004, 190; Marton - Regenye 2005, 50. 
in Transdanubia. ${ }^{467}$ Thus, it is reasonable to assume burials possibly older by generations than the tumuli around the settlement. It might be dangerously close to speculation, yet it is worth posing the question whether we might reckon with graves even older than the urn burial. If yes, would they form a cemetery continuously used since the late Urnfield period?

\section{Summary}

The prehistoric site Tihany-Óvár has been a widely-known Late Bronze and Early Iron Age hilltop settlement and a tumulus cemetery since the late $19^{\text {th }}$ century, however, the first documented archaeological investigations did not start until the 1970s. In the course of the rescue excavation András Uzsoki opened three mounds under the hillfort. Regrettably, there is no available information concerning one of them (Tumulus 3).

The two graves unearthed during this campaign show utterly different features, but they are easily comparable with the Hallstatt Age burials of Transdanubia in general. To begin with, it is worth pointing out that they represent different grave forms. Set aside that both graves seem to have been covered by stone blocks, Grave 2 had a stone-lined, rectangular burial pit, but it is questionable whether it was covered by a mound. Contrary to that, inside Tumulus 1 no structure of any kind has been found. The burial rite seems quite different as well. Under Tumulus 1 Uzsoki found a feature that in my view suggests that this grave is a Bustumgrab, i.e. the mound was erected over the exact location of the funeral pyre. In addition, and contrary to Grave 2, the human remains were not put in an urn neither were collected. One of the characteristics of the Bustumgrab was the fragmentary state of the vessels. As it turned out, they cannot be entirely reconstructed and the different marks of secondary burning on matching sherds lead to the assumption that they were not intact when they were placed onto the funeral pyre. Hence the presumption that these might be referred to as 'pyre goods' instead of 'grave goods'. As opposed to this situation, the stone-lined grave yielded six vessels, and all of them could have been placed into the grave in a whole, which also alludes to the quite different rites performed during the two funerals. Furthermore, set aside that both graves yielded vessels representing common types in Transdanubia in general, the vessels found in Tumulus 1 seem to be closely linked to the vessel sets of the richly furnished tumulus burials of Transdanubia, Styria, North-Eastern Slovenia and Northern Croatia. The stone-lined grave yielded a significantly modester set rather similar to the ones found in the so-called flat cemeteries, for instance Halimba and Nagydém-Középrépáspuszta. Contrary to the mounds, however, the Tihany tumulus did not yield any weapons, and it is doubtful whether the remained metal finds might be interpreted as elements of horse harness. Metal objects have not been recovered from the stone-lined grave.

One of the main questions is what the reason for these dissimilarities might be. One possibility is that the chronological distance between the two is responsible for the above-listed differences. Tumulus 1 dates to the Ha C2-D1 phase, its age can hardly be ascertained more accurately due to the lack of characteristic metal finds. In spite of the fact that the stone-lined grave can only be dated in broad terms, too, ie. Ha C1-C2, it seems reasonable to believe, based chiefly on typological considerations, that it is at least somewhat older than Tumulus 1 . 
On the other hand, another possible explanation for the differences might be supposing a certain social distance between the two burials. There are several features of the two graves supporting this assumption; just to mention one example, contrary to Grave 2 Tumulus 1 yielded metal finds. I would like to emphasise that the aforementioned two possible explanations are not necessarily exclusive.

Finally, I would like to briefly touch upon the question of the cemetery under the prehistoric hillfort, Tihany-Óvár. The five hitherto identified tumuli clearly indicate that a small graveyard was used during the Hallstatt Age, yet one has to keep in mind that the settlement dates back at least to the Ha B3 phase. Consequently, arises the question, whether Grave 2 might allude to a 'flat' cemetery in close vicinity of the tumuli and the settlement that might also include burials from earlier phases. However, without further investigations on the site the above questions can hardly be answered. I hope future investigations around Tihany will reveal the needed data and help broadening our knowledge about the Hallstatt Age of this remarkable site on the peninsula.

\section{Appendix - Catalogue}

\subsection{Ceramic material from Tumulus 1}

In the case of 321 fragments we were not able to identify the vessel type nor the vessel they belonged to. However, in the following table I would like to present some general characteristic feature regarding this part of the ceramic assemblage. ${ }^{468}$

\begin{tabular}{|c|c|c|c|c|}
\hline Profile & $\begin{array}{c}\text { Surface } \\
\text { treatment }\end{array}$ & Graphited & Polished $^{467}$ & Smoothed \\
\hline \multicolumn{2}{|l|}{ Rim } & - & 3 & - \\
\hline \multicolumn{2}{|c|}{ Rim-neck line } & 1 & - & - \\
\hline \multicolumn{2}{|l|}{ Neck } & 47 & 1 & - \\
\hline \multicolumn{2}{|c|}{ Neck-shoulder line } & 18 & - & - \\
\hline \multicolumn{2}{|l|}{ Belly } & 63 & - & - \\
\hline \multicolumn{2}{|l|}{ Side } & 40 & 113 & 38 \\
\hline \multicolumn{2}{|l|}{ Bottom } & - & - & 4 \\
\hline
\end{tabular}

V01: 23 fragments (inv. no. 71.10.55, 71.10.52., 71.10.68., 71.10.69., 71.10.70, 71.10.71)

Material: Ceramic, finely tempered with sand and grained ceramic. The outer surface is dark grey with brown spots. The inner surface is dark grey with brown and light grey spots. The exterior is graphited.

Shape: Slightly outcurving and thickening rim, slightly curving and conical neck. The neck and the shoulder is divided by a fluted line. A thick strap handle is running from the shoulder-neck line to the neck. The vessel has a bulging belly and conical lower part.

468 Abbreviations: $\mathrm{H}$ - Height, DR - Diameter of the rim, MD - Maximal diameter, HMD - Height of the maximal diameter, DB - Diameter of the bottom, Inv. no. - Inventory number

469 It may be assumed that the graphit coating disappeared due to secondary burning. On the other hand, one should also bear in mind that this kind of surface treatment is prone to the chemical properties of the surrounding earth. (VADÁsz 1986a, 223) 
Decoration: Three knobs on the shoulder enclosed by multiple V-lined flutes. The handle bears three vertical ribs.

Dimensions: DR: 320 mm; MD: 460 mm; HMD: $146 \mathrm{~mm}$ (from the rim)

V01F01 fragments: 12 fragments (inv. no. 71.10.56., 71.10.68)

Material: Ceramic, finely tempered with sand and grained ceramic. The outer surface is dark grey with brown and reddish-brown spots (secondarily burnt). The inner surface is dark grey with brown and light grey spots. The exterior is graphited.

Shape: Bulging parts of the vessel's belly.

Decoration: V-lined flutes.

V02 vessel: 15+2(?) fragments (inv. no. 71.10.68, 71.10.69., 71.10.70., maybe 71.10.65.)

Material: Ceramic, finely tempered with sand and grained ceramic. Fragments with different colour. The exterior is graphited.

Shape: Slightly outcurving and thickening rim. The neck and the shoulder is divided by a flute. A thick strap handle is running from the shoulder-neck line to the neck. The vessel has a bulging belly and conical lower part.

Decoration: Knobs on the shoulder enclosed by 'V'-lined flutes. The handle bears three vertical ribs.

Dimensions: DR: $360 \mathrm{~mm}$; MD: $560 \mathrm{~mm}$; HMD: $155 \mathrm{~mm}$ (from the rim)

V02F01: 6 fragments (inv. no. 71.10.65)

Material: Ceramic, finely tempered with sand and grained ceramic. The exterior is dark grey, black, the interior is dark grey. The exterior bears traces of polishing.

Shape: Bottom of the vessel.

Dimensions: DB: $155 \mathrm{~mm}$

V02F02: 10 fragments (inv. no. 71.10.52.)

Material: Ceramic, finely tempered with sand and grained ceramic. The exterior is dark grey, black, the interior is dark grey with brown spots (secondarily burnt). The exterior and the interior of the rim are graphited.

Shape: Straight, slightly thickening rim, slightly curving neck.

Dimensions: DR: $360 \mathrm{~mm}$

V02F03: 4 fragments (inv. no. 71.10.68.)

Material: Ceramic, finely tempered with sand and grained ceramic. The exterior is grey, dark grey with red spots, the interior is dark grey, brown with red spots (secondarily burnt).

Shape: Slightly curving neck, strongly bulging fragment. The neck and the shoulder is divided by a flute.

Decoration: Knobs on the shoulder enclosed by 'V'-lined cannelures.

V03: (inv. no. 71.10.33., 71.10.60 71.10.68.)

Material: Ceramic, finely tempered with sand and grained ceramic. The exterior is red, grey, dark grey with light brown spots, the interior is brown, red with grey spots (secondarily burnt). On the surfaces of the vessel traces of graphite can be observed.

Shape: Straight rim, slightly curving neck, marked neck-shoulder line, and slight carination. A strap handle is attached to the neck-shoulder line.

Decoration: Three knobs are situated on the neck-shoulder line. The belly is decorated with triangles of fluted lines with hatching. The strap handle bears three vertical ribs.

Dimensions: DR: 245 mm; MD: 320 mm; HMD: 69 mm (from the rim); DB: $90 \mathrm{~mm}$ 
V03F01: 1 fragment (inv. no. 71.10.60)

Material: Ceramic, finely tempered with sand and grained ceramic. The exterior is dark grey with brown spots, the interior is red.

Shape: Part of the vessel's belly, with a thick strap handle attached to it.

Decoration: oblique cannelures, the handle bears three vertical ribs.

V03F02: 3 fragments (inv. no. 72.10.40).

Material: Ceramic, finely tempered with sand and grained ceramic. Dark grey, brown, red spotted fragments (secondarily burnt).

Shape: Fragment of a handle raised above the rim bearing horns.

Decoration: Three vertical ribs

V04: (inv. no. 71.10.66., 71.10.69)

Material: Ceramic, finely tempered with sand. The exterior is black, dark grey, the interior is dark brown; this top layer is frequently flaking off. Polished surface, scantly traces of graphite.

Shape: Funnel-shaped rim, conical neck, distinctive rim-neck and neck-shoulder line, bulging body with conical lower part.

Decoration: Vertical thin flutes on the belly.

Dimensions: DR: $330 \mathrm{~mm}$; MD: $410 \mathrm{~mm}$; HMD: $120 \mathrm{~mm}$ (from the rim)

V04F01: 2 fragments (inv. no. 72.10.62)

Material: Ceramic, finely tempered with sand. The exterior is black, dark grey, the interior is grey, brown spotted. Polished surface.

Shape: Conical lower part ending in a flat bottom.

Dimensions: DB: $100 \mathrm{~mm}$

V05: 28 fragments (inv. no. 71.10.68., 71.10.67., 71.10.70)

Material: Ceramic, finely tempered with sand and grained ceramic. The exterior is grey, reddish-brown, grey spotted, the interior is dark grey, grey, brown (secondarily burnt). The outer surface is graphited.

Shape: Funnel-shaped rim, conical neck, bulging body, distinctive rim-neck and neck-shoulder line.

Dimensions: DR: $305 \mathrm{~mm}$; MD: $630 \mathrm{~mm}$ (?); HMD: $300 \mathrm{~mm}$ (from the rim).

V05F01: 1 fragment (inv. no. 71.10.68)

Material: Ceramic, coarse-tempered. The exterior is light grey, reddish-brown spotted, the interior is dark grey. Traces of graphite on the outer surface.

Shape: Slightly curving conical neck, bulging body.

Decoration: Knobs on the shoulder enclosed by multiple V-lined flutes hanging from the neck-shoulder line.

V05F02: 6 fragments (inv. no. 72.10.68)

Material: Ceramic, coarse-tempered. The exterior is grey, red spotted, the interior is red, reddish-brown, grey spotted.

Shape: Slightly curving conical neck, bulging body.

Decoration: Oblique fluted lines on the shoulder of the vessel.

V05F03: 5 fragments (inv. no.72.10.68)

Material: Ceramic, coarse-tempered. The exterior is dark grey, grey, reddish-brown, grey spotted, the interior is dark grey, light brown, light grey spotted (secondarily burnt).

Shape: Slightly curving conical lower part of the vessel ending in a flat bottom.

Dimensions: DB: $130 \mathrm{~mm}$ 
V05F04: 1 fragment (inv. no. 72.10.78)

Material: Ceramic, finely tempered with sand and grained ceramic. The exterior is dark grey, brown, reddish-brown spotted, the interior is brown, light brown, grey and red spotted. The outer surface bears traces of graphite.

Shape: Funnel-shaped rim.

Decoration: Flute marking the rim-neck line.

Dimensions: DR: $290 \mathrm{~mm}$

V05F05: 4 fragments (inv. no. 72.10.70)

Material: Ceramic, finely tempered with sand and grained ceramic. The exterior and the interior are dark grey, back. The outer surface bears traces of graphite.

Shape: Funnel-shaped rim.

Dimensions: DR: $290 \mathrm{~mm}$

V06: 9 fragments (inv. no. 71.10.53., 71.10.76.)

Material: Ceramic, coarse-tempered. The exterior is dark grey, black, brown spotted, the interior is black, dark grey, brown spotted. The outer surface is polished.

Shape: Outcurving rim, curving neck, distinctive neck-shoulder line, slightly curving conical lower part. Situla-shaped vessel.

Dimensions: H: 201 mm; DR: 190 mm; MD: 230 mm; HMD: 60 mm (from the rim); DB: $120 \mathrm{~mm}$

V07: inv. no. 72.10.54.

Material: Ceramic, coarse-tempered. The exterior is red, yellow spotted, grey on the rim, the interior is grey with lighter and darker spots (secondarily burnt).

Shape: Thickened, straight rim, bulging big vessel, flat bottom.

Decoration: Cordon on the neck decorated with finger-tip impressions.

Dimensions: DR: 240-280 mm; MD: $330 \mathrm{~mm}$; HMD: $125 \mathrm{~mm}$ (from the rim); DB: $120 \mathrm{~mm}$.

V08: 10 fragments (inv. no. 72.10.57., 72.10.68)

Material: Ceramic, finely tempered with sand. The exterior is black, dark grey, the interior is dark grey. The outer surface is graphited.

Shape: Slightly curving conical neck, bulging body. Distinctive neck-shoulder line.

Decoration: Knobs on the shoulder enclosed by multiple fluted V-lines.

Dimensions: MD: $450 \mathrm{~mm}(?)$

V08F01: 5 fragments (inv. no. 72.10.51., 71.10.68., 71.10.70)

Material: Ceramic, finely tempered with sand. The exterior is dark grey, black, red and grey spotted, the interior is black, dark grey, to some extent red.

Shape: Straight rim, slightly curving conical neck, a strap handle is attached to the neck just below the rim.

Decoration: Fluted line marking the rim-neck line.

Dimensions: DR: $310 \mathrm{~mm}$

V09: 6 fragments (inv. no. 72.10.31)

Material: Ceramic, finely tempered with sand and grained ceramic. The exterior is red, slightly grey spotted, the interior is dark grey. On the outer surface only traces of graphite can be observed, the inner surface is entirely graphited.

Shape: Straight rim, globular body, pedestal-like lower part with strongly curved profile. A handle is attached to the body.

Decoration: Multiple fluted V-lines, horizontal flutes on the top of the pedestal.

Dimensions: H: 72 mm; DR: 120 mm; MD: 128 mm; HMD: 58 mm; BD: 54 mm 
V10: 11 fragments (inv. no. 72.10.15.; 72.10.25)

Material: Ceramic, finely tempered with sand. The exterior is black, dark grey, brown with grey and brownish-grey spots, the interior is black, dark grey with brown, dark grey and greyishbrown spots (secondarily burnt). The outer surface is polished.

Shape: Inverted, faceted rim, curving conical lower part.

Decoration: The interior is decorated with multiple graphited lines intersecting at the bottom of the vessel, multiple graphited V-lines hanging form the rim on the interior.

Dimensions: H: 53 mm; DR: 170 mm; DB: 54 mm

V11: 6 fragments (inv. no. 72.10.16)

Material: Ceramic, finely tempered with sand. The exterior is dark grey, red with brown spots, the interior is dark grey, red with brown spots (secondarily burnt). The outer as well as the inner surface is polished.

Shape: Straight rim, globular body, bottom with omphalos.

Decoration: The interior is decorated with multiple graphited lines intersecting at the bottom of the vessel, multiple graphited V-lines hanging form the rim on the interior.

Dimensions: H: $50 \mathrm{~mm}$; DR: $150 \mathrm{~mm}$; DB: $30 \mathrm{~mm}$

V12: 8 fragments (inv. no. 72.10.17)

Material: Ceramic, finely tempered with sand. The exterior is dark grey with brown spots, the interior is grey with brown spots. The outer surface bears traces of polishing.

Shape: Straight rim, globular body.

Dimensions: H: 48 mm; DR: 130 mm; DB: 28 mm.

V13: 8 fragments (inv. no. 72.10.23.; 72.10.25)

Material: Ceramic, finely tempered with sand and grained ceramic. The exterior is grey with red and light brown spots, the interior is grey with red spots.

Shape: Slightly incurving rim, distinct carination on the body.

Dimensions: DR: $130 \mathrm{~mm}$; MD: $134 \mathrm{~mm}$; HMD: $20 \mathrm{~mm}$ (from the rim).

V14: 9 fragments (inv. no. 72.10.24)

Material: Ceramic, finely tempered with sand and grained ceramic. The exterior is light grey with red spots, the interior is dark grey with light brown and red spots. On the outer surface traces of polishing could be observed.

Shape: Slightly incurving rim, distinct carination on the body.

Decoration: Fishbone pattern of fluted lines in sections following each-other in a distance of $39 \mathrm{~mm}$.

Dimensions: DR: $140 \mathrm{~mm}$; MD: $145 \mathrm{~mm}$; HMD: $14 \mathrm{~mm}$ (from the rim).

V15: 13 fragments (inv. no. 72.10.28)

Material: Ceramic, finely tempered with sand and grained ceramic. The exterior is dark grey, grey, red with brown and grey spots, the interior is dark grey, red with brown and grey spots.

Shape: Conical bowl with pedestal.

Decoration: Triangles filled with hatching of flutes. The triangles are confined to horizontal bands bordered by horizontal double channelled lines.

Dimensions: DR: $290 \mathrm{~mm}$.

V16: 9 fragments (inv. no. 72.10.13)

Material: Ceramic, finely tempered with sand. The exterior is brown with dark grey spots, the interior is brown and dark grey on the rim.

Shape: Flat, curved conical lid. 
Decoration: zigzagging double channeled lines (in a shape of a star) in a band bordered by two lines of double channeled lines.

Dimensions: DR: $200 \mathrm{~mm}$

V17: 12 fragments (inv. no. 72.10.14)

Material: Ceramic, finely tempered with sand. The exterior is black, dark grey with brown spots, the interior is dark grey with brown spots. The outer surface is polished.

Shape: Flat globular lid.

Decoration: Double lines of cannelures perpendicular to each-other. They are bordered by V-lines painted with graphite in the four areas.

Dimensions: DR: $190 \mathrm{~mm}$.

V18: 12 fragments (inv. no. 72.10.18)

Material: Ceramic, finely tempered with sand and grained ceramic. The exterior is grey, dark grey with brown and dark grey spots, the interior is grey with red spots. The outer surface bears traces of graphite.

Shape: Flat, curved conical lid.

Decoration: Three-branched swastikas of cannelures.

Dimensions: DR: $280 \mathrm{~mm}$.

V19: 5 fragments (inv. no. 72.10.22)

Material: Ceramic, finely tempered with sand. The exterior is black, dark grey with red spots, the interior is dark grey. The outer surface is graphited.

Shape: Flat, slightly curved conical lid.

Decoration: On the edge of the rim there are impressions followed by two lines of cannelure.

Dimensions: DR: $195 \mathrm{~mm}$.

V20: 2 fragments (inv. no. 72.10.20)

Material: Ceramic, finely tempered with sand. The exterior is grey, dark grey with brown spots, the interior is light grey and dark grey with brown spots (secondarily burnt?).

Shape: Flat, slightly curved conical lid.

Decoration: Densely spaced oblique incised lines running from the rim.

Dimensions: DR: $185 \mathrm{~mm}$.

V21: 8 fragments (inv. no. 72.10.26)

Material: Ceramic, finely tempered with sand. The exterior is dark grey, red with grey spots, the interior is dark grey and red with dark grey spots (secondarily burnt). Traces of polishing can be seen.

Shape: Slightly curved conical (concave) lid.

Decoration: Cannelures in $\widehat{\bigwedge}$ shape raising from the rim. Spiral lines of cannelures are situated on the upper part of the fragments

Dimensions: DR: $160 \mathrm{~mm}$.

V22: 4 fragments (inv. no. 72.10.27)

Material: Ceramic, finely tempered with sand. The exterior is dark grey, red with grey spots, the interior is dark grey and red with grey and red spots (secondarily burnt).

Shape: Slightly curved conical (concave) lid, the handle is missing.

Decoration: Channelled V-lines can be seen by the rim.

Dimensions: DR: $170 \mathrm{~mm}$.

IF23: 3 fragments (inv. no. 72.10.29)

Material: Ceramic, finely tempered with sand. The exterior is red, dark brown, the interior is dark brown. 
Shape: Handle of lid, strongly outcurving rim with cylindrical body.

Decoration: Horizontal cannelures just below the outcurving rim of the handle.

Dimensions: DR: $65 \mathrm{~mm}$.

1F24: 4 fragments (inv. no. 72.10.30)

Material: Ceramic, finely tempered with sand. The exterior is red, dark brown, the interior is dark brown and dark grey (secondarily burnt).

Shape: Handle of lid, strongly outcurving rim with cylindrical body.

Decoration: Horizontal cannelures just below the outcurving rim of the handle.

Dimensions: DR: $65 \mathrm{~mm}$.

1F25: 2 fragments (inv. no. 72.10.19)

Material: Ceramic, finely tempered with sand. The exterior is grey with brown spots, the interior is brownish-grey.

Shape: Curved conical lid.

Dimensions: DR: $165 \mathrm{~mm}$.

IF26: 1 fragment (inv. no. 72.10.21)

Material: Ceramic, finely tempered with sand. The exterior is grey with red spots, the interior is red.

Shape: Curved conical lid.

Dimensions: DR: $185 \mathrm{~mm}$.

1F27: 4 fragments (inv. no. 72.10.44)

Material: Ceramic, finely tempered with sand. The exterior is grey with brown spots, the interior is brownish-grey.

Shape: Conical side of a vessel (probably lid).

Decoration: S-shaped spirals of cannelures and perpendicular fluted lines.

rF28: 1 fragment (inv. no. 72.10.47)

Material: Ceramic, finely tempered with sand and grit. The exterior is black, the interior is dark grey with brown spots. The outer surface is graphited.

Shape: Strongly outcurving, thickening rim.

Decoration: Wide, horizontal cannelures on the neck.

Dimensions: DR: $260 \mathrm{~mm}$

rF29: 1 fragment (inv. no. 72.10.45)

Material: Ceramic, coarse-tempered. The exterior is light brown with grey spots, the interior is grey with light grey and light brown spots. The outer surface is coarse, the inner surface is smoothed.

Shape: Slightly outcurving, slightly thickening rim, curved neck, to some extent distinct neck-shoulder line.

Decoration: Finger-tip impressions below the neck-shoulder line.

Dimensions: DR: $210 \mathrm{~mm}$

rF30: 1 fragment (inv. no. 72.10.77)

Material: Ceramic, organic-tempered. The exterior is brownish-grey with light brown spots, the interior is grey. Coarse surfaced.

Shape: Slightly ooutcurving, slightly thickening rim, curving neck, to some extent distinct neck-shoulder line.

Dimensions: DR: $290 \mathrm{~mm}$ 
rF31: 2 fragments (inv. no. 72.10.61)

Material: Ceramic, finely tempered with sand and grit. The exterior is grey with reddish-brown spots, the interior is reddish-brown with grey spots.

Shape: Slightly ooutcurving, slightly thickening rim.

Decoration: Finger-tip impressions on the rim.

Dimensions: DR: 270 (?) mm

bF32: 2 fragments (inv. no. 72.10.72)

Material: Ceramic, finely tempered with sand and grained ceramic. The exterior is reddish-brown with grey spots, the interior is black with red spots.

Shape: Slightly concave conical side ending in a flat bottom.

Dimensions: BR: $200 \mathrm{~mm}$

bF33: 2 fragments (inv. no. 72.10.63)

Material: Ceramic, coarse-tempered. The exterior is black with reddish-brown spots, the interior is dark grey with light grey and reddish-brown spots (secondarily burnt). Coarse-surfaced.

Shape: Slightly concave conical side ending in a flat bottom.

Dimensions: DR: $110 \mathrm{~mm}$

bF34: 5 fragments (inv. no. 72.10.63)

Material: Ceramic, coarse-tempered. The exterior is dark grey with black spots, the interior is light grey with brown spots.

Shape: Slightly concave conical side ending in a flat bottom.

Dimensions: DR: $150 \mathrm{~mm}$

bF35: 2 fragments (inv. no. 72.10.68)

Material: Ceramic, coarse-tempered. The exterior is grey, dark grey with brown spots, the interior is grey and brown (secondarily burnt?)

Shape: Slightly concave conical side ending in a flat bottom.

Dimensions: DR: $150 \mathrm{~mm}$

bF36: 2 fragments (inv. no. 72.10.61)

Material: Ceramic, finely tempered with sand and grained ceramic. The exterior is dark grey and black, the interior is light brown with red spots. Due to secondary burning the outer surface is flaking off.

Shape: Slightly concave conical side ending in a flat bottom.

Dimensions: DR: $150 \mathrm{~mm}$

bF37: 1 fragment (inv. no. 72.10.73)

Material: Ceramic, coarse-tempered. The exterior is dark grey and black, the interior is dark grey. The outer surface bears traces of polishing.

Shape: Slightly concave conical side ending in a flat bottom.

Dimensions: DR: $140 \mathrm{~mm}$

bF38: 1 fragment (inv. no. 72.10.74)

Material: Ceramic, coarse-tempered. The exterior is dark grey with brown spots, the interior is reddish-brown.

Shape: Slightly concave conical side ending in a flat bottom.

Dimensions: DR: $125 \mathrm{~mm}$

bF39: 1 fragment (inv. no. 72.10.75)

Material: Ceramic, finely tempered with sand. The exterior is black and dark grey, the interior 
is dark grey with brown spots. The outer surface is polished, the inner surface bears traces of polishing.

Shape: Slightly concave conical side ending in a flat bottom.

Dimensions: DR: $140 \mathrm{~mm}$

bF40: 1 fragment (inv. no. 72.10.58)

Material: Ceramic, tempered with grit. The exterior is dark grey with brown spots, the interior is brownish-grey with light grey spots.

Shape: The upper part of a straight pedestal.

Decoration: Three horizontal fluted lines on the upper part of the fragment.

sF41: 1 fragment (inv. no. 72.10.39)

Material: Ceramic, coarse-tempered. The exterior and the interior are dark grey and black. The exterior as well as the interior are graphite-coated.

Shape: Curving side of a vessel.

Decoration: A curving, horn-shaped, broken knob on the side.

sF42: 1 fragment (inv. no. 72.10.42)

Material: Ceramic, finely tempered with sand and grained ceramic. The exterior is red, the interior is red with grey spots. The exterior as well as the interior bear traces of graphite-coating.

Shape: Curving side of a vessel.

Decoration: Curving line of flute accompanied by a line of dot-like impressions.

sF43: 3 fragments (inv. no. 72.10.48)

Material: Ceramic, finely tempered with grained ceramic. The exterior is dark grey with brown spots, the interior is black.

Shape: Curving side of a vessel.

Decoration: The inner surface bears a graphite-painted rhomboid motive.

sF44: 1 fragment (inv. no. 72.10.49)

Material: Ceramic, finely tempered with grained ceramic. The exterior is black, the interior is black with red spots.

Shape: Curving side of a vessel with a distinct neck-shoulder line.

Decoration: Part of a pattern comprising graphite-painted rhomboid motives.

Dimensions: MD: 290 (?) mm

sF45: 1 fragment (inv. no. 72.10.81)

Material: Ceramic, finely tempered with sand and grained ceramic. The exterior and the interior are dark grey with dark brown spots. The exterior bears graphite-coating.

Shape: Curving side of a vessel.

Decoration: Multiple fluted lines.

F46: 1 fragment (inv. no. 72.10.38)

Material: Ceramic, finely tempered with sand. Grey and brown.

Shape: Curving prism-shaped piece (part of a handle).

F47: 2 fragments (inv. no. 72.10.37)

Material: Ceramic, finely tempered with sand and grained ceramic. Grey and brown.

Shape: Curving, horn-shaped knobs.

F48: 1 fragments (inv. no. 72.10.39)

Material: Ceramic, finely tempered with sand and grained ceramic. Grey and brown.

Shape: Shaped like a head of a bird. 
F49: 18 fragments (inv. no. 72.10.32, 72.10.41)

Material: Ceramic, finely tempered with sand and grained ceramic. The exterior is dark grey, reddish-brown, red, the interior is red, dark grey, brownish-red (secondarily burnt). The exterior as well as the interior bears traces of graphite-coating.

Shape: Curving side of a vessel.

Decoration: Triangles filled with hatching of flutes with spiral lines attached to their angles. Spirals of fluted lines. Rectangular, plastic spirals.

Spindle-whorl: (inv. no. 72.10.34.)

\subsection{Metal finds of the tumulus}

Inv. no. $72.10 .2 ; 72.10 .10$.

Description: 2 iron rings of the same diameter and hexagonal cross-section. One of them is broken. D: $30 \mathrm{~mm}$; W: 5-6 mm.

2 curved iron fragments corroded together, presumably pieces of a similar ring. W: $4.7 ; 5.3 \mathrm{~mm}$, L: 17 and $14 \mathrm{~mm}$

Inv. no. 72.10 .3 .

Description: Two whole and one in fragmentary state.

Dimensions: Diameter of the ring: 10.3-12 mm, diameter of the button: 9.5-9.7 mm.

Inv. no. 72.10.1.

Description: 27 pieces are in fragmentary state, partly melted. 34 pieces of whole bronze rings, perhaps chain links.

Dimensions: D: 5-8 mm, W: 1-1.5 mm.

Inv. no. 72.10.1.

Description: 3 pieces. Their diameter and the width of the bronze wire is comparable with the dimensions of the small bronze rings presented above.

Inv. no. $72.10 .4 ; 72.10 .8$.

Curved bronze fragments, presumably pieces of bronze rings, one of which bears a loop (possibly melted to it) (Fig. 14.6).

Dimensions: W: 4.8-5.1, 6.2 mm L: 23.6; 17.7; 17.8, $17.2 \mathrm{~mm}$

Inv. no. 72.10.6.

Acoording to the museums inventory 5 pieces have been discovered during the excavation, however, only 2 can be found among the objects. It could hardly be discerned what kind of object they could have been belonged to (Fig. 14.7).

Dimensions: D: 7.4-7.7 mm

Inv. no. 72.10.5.

6 pieces with different dimensions (the smallest is $5 \times 8$ millimeter, the largest is $25 \times 13$ millimeter).

They bear no decoration of any kind (Fig. 14.8).

Inv. no. 72.10 .7 .

Melted fragments of objects made of bronze sheets. Their original shape is hardly discernible. Part of a recurved rim can be observed in one case (Fig. 14.9).

Dimensions: L: $10.7 \mathrm{~mm} ; 21.6 \mathrm{~mm} ; 27.9 \mathrm{~mm}$ 
Inv. no. 72.10 .11 .

Small fragment, uncertain (Fig. 14.10).

Dimensions: L: $27.8 \mathrm{~mm}$; W: $7.1 \mathrm{~mm}$.

Inv. no. 72.10 .8 .

Melted bronze fragments attached to calcined bones

\subsection{Ceramic finds from the stone-lined grave}

G1 vessel (inv. no. 72.2.1.)

Material: Ceramic, finely tempered with grained ceramic, both the outer and inner surface is grey, dark grey, with brown spots.

Surface treatment: The inner side is smoothed, the outer is polished.

Shape: Outcurving and thickening rim, slightly curving and conical neck. The neck and the shoulder is divided by a fluted line marking transition from the neck to the shoulder. Slightly sharp belly-line. The lower part is concave conical, the bottom is flat.

Decoration: Three evenly spaced knobs along the line between the neck and the shoulder.

Dimensions: H: 36 cm; DR: 24.8 cm; MD: $41.4 \mathrm{~cm}$; HMD: $16.4 \mathrm{~cm}$; DB: $15.5 \mathrm{~cm}$

G2 vessel (inv. no.: 72.2.3.)

Material: Ceramic, finely tempered with grained ceramic, both the outer and inner surface is grey, dark grey, with brown spots mainly on the interior.

Surface treatment: The interior side is smoothed, the exterior and the inner side of the rim are polished.

Shape: Slightly outcurving and thickening rim, slightly curving and conical neck. Bulging shoulder and belly. The lower part is concave conical, the bottom is flat.

Decoration: Densely placed slanting cannelures on the shoulder and the belly.

Dimensions: H: 22.6 cm; DR: 24.3 cm; MD: 32.4 cm; HMD: 12.2 cm; DB: 13.9 cm

G3 vessel (inv. no. 72.2.2.)

Material: Ceramic, finely tempered with grained ceramic, both the outer and the inner surface is grey, dark grey, with brown spots mainly on the interior.

Surface treatment: The interior side is smoothed, the exterior and the inner side of the rim are polished.

Shape: Slightly outcurving and thickening rim, slightly curving and conical neck. The neck and the shoulder is divided by a fluted line. A thick strap handle is running from the shoulder-neck line to the neck. The vessel has a bulging belly and conical lower part. The bottom is flat.

Decoration: Densely placed slanting cannelures on the shoulder and belly.

Dimensions: H: 17.5 cm; DR: 21.8 cm; MD: 26.5 cm; HMD: 10.6 cm; DB: $9.6 \mathrm{~cm}$.

G4 vessel (inv. no. 72.2.4.)

Material: Ceramic, finely tempered with grained ceramic, both the outer and inner surface is grey, dark grey, with brown spots.

Surface treatment: The interior side is smoothed, the exterior and the inner side of the rim are polished.

Shape: Small bowl with inverted rim and slightly curving conical lower part. The bottom is flat.

Decoration: Slanting faceted rim resembling turban-like rims.

Dimensions: H: $6.1 \mathrm{~cm}$; DR: $17.7 \mathrm{~cm}$; MD: $19.8 \mathrm{~cm}$; DB: $6.8 \mathrm{~cm}$

G5 vessel (inv. no. 72.2.6.) 
Material: Ceramic, finely tempered with grained ceramic, both the outer and the inner surface is grey, dark grey, with brown spots.

Surface treatment: The interior side is smoothed, the exterior and the inner side of the rim are polished.

Shape: Small bowl with inverted rim and slightly curving conical lower part. The bottom is omphalic.

Decoration: Slanting faceted rim similar to turban-like rims, below the rim four evenly spaced knobs.

Dimensions: H: $6.2 \mathrm{~cm}$; DR: $16.5 \mathrm{~cm}$; MD: $16.7 \mathrm{~cm}$; DB: $5.1 \mathrm{~cm}$

G6 vessel (inv. no. 72.2.5.)

Material: Ceramic, finely tempered with grained ceramic, both the outer and the inner surface is grey, dark grey, with brown spots.

Surface treatment: The interior side is smoothed, the exterior is polished.

Shape: Small bowl with slightly inverted rim and globular lower part. The bottom is flat.

Decoration: Below the rim four evenly spaced knobs.

Dimensions: H: 7.3 cm; DR: 17.8 cm; MD: $18.1 \mathrm{~cm}$ HDM: 6 cm; DB: $6.8 \mathrm{~cm}$

\section{References}

ArTNER, W. 1996: Neue hallstattzeitliche Grabfunde aus Leibnitz-Altenmarkt, Steiermark. Archäologie Österreichs 7/1, 48-52.

BAKAY, K. - KALICZ, N. - SÁGI, K. 1966: Veszprém megye régészeti topográfiája. A keszthelyi és tapolcaijárás Magyarország régészeti topográfiája 1 . Budapest.

BAKAY, K. - Kalicz, N. - SÁGI, K. 1970: Veszprém megye régészeti topográfiája. A devecseri és sümegi járás Magyarország régészeti topográfiája 3. Budapest.

BARB, A. 1937: Hügelgräbernekropolen und frühgeschichtliche Siedlung im Raume der Gemeinden Schandorf und Pinkafeld (Burgenland). Mitteilungen der Anthropologischen Gesellschaft 67, 74-118.

BARTH, F. 1970: Katalog der ausgestellten Funde. In: Krieger und Salzherren: Hallstattkultur im Ostalpenraum. Ausstellung des Naturhistorischen Museums in Wien in der Neuen Galerie der Stadt Linz, vom 7. September bis 24. Oktober 1971. Mainz, 151-194.

Bernhard, A. - WeIHS, A. 2003: Neuerforschte Gräber der frühen Eisenzeit in Kleinklein (Weststeiermark). Universitätsforschungen zur prähistorischen Archäologie 93. Bonn.

Bernhard, A. - Fuchs, G. 2004: Urnenfelderzeitliche Hügelgräber beim Glaserkogel in der Weststeiermark. Fundberichte aus Österreich 43, 213-274.

BERTHOLD, B. 1998: Bronze-, urnenfelder- und früheisenzeitliche Keramikdeponierungen in Süddeutschland. In: Berthold, B. - KAhler, E. - KAS, S. (Eds.): Zeitenblicke. Festgabe für Walter Fanssen. Leidorf, 25-72.

BóNA, I 1975: Die mittlere Bronzezeit Ungarns und ihre südöstliche Beziehungen. Archaeologia Hungarica 49. Budapest

Brosseder, U. 2004: Studien zur Ornamentik hallstattzeitlicher Keramik zwischen Rhonetal und Karpatenbecken. Universitätsforschungen zur prähistorischen Archäologie 106. Bonn.

ChropovskÝ, B. 1955: Výskum halštatskej mohyly v Réci (Fouilles d'un tumulus hallstattien de Rica). Archeologické Rozhledy 7, 769-771.

DARnAY, B. 1899: A zala-szántói halmok és két magyar lovas sír. Archaeologiai Értesítő 19, 276-280.

Doвiat, C. 1980: Das hallstattzeitliche Gräberfeld von Kleinklein und seine Keramik. Schild von Steier Beiheft 1. Graz.

Dular, J. 1982: Halštatska keramika v Sloveniji: prispevek k proučevanju halštatske grobne keramike in lončarstva na Dolenjskem (Die Grabkeramik der älteren Eisenzeit in Slowenien). Ljubljana. 
Dular, J. 2013: Severovzhodna Slovenija v pozni bronasti dobi (Nordostslowenien in der späten Bronzezeit). Opera Instituti Archaeologici Sloveniae 27. Ljubljana.

Dular, J. - Tomanič Jevremov, M. 2010: Ormož. Utrjeno naselje iz pozne bronaste in starejse zelezne dobe (Ormož. Befestigte Siedlung aus der späten Bronze- und der älteren Eisenzeit). Opera Instituti archaeologici Sloveniae 18. Ljubljana.

Ďurкovič, É. 2009: Kora vaskori temető Fertőrákos-Kőhidai dűlőn (Früheisenzeitliches Gräberfeld in Fertőrákos-Kőhidai dűlő). Communicationes Archaeologicae Hungariae 2009, 51-83.

DušEk, M. 1966: Thrakisches Gräberfeld der Hallstattzeit in Chotin. Bratislava.

DušEk, M. 1976: Junghallstattzeitliches Gräberfeld von Modrany. Slovenská Archeológia 24, 397-427.

EGG, M. 1985: Die hallstattzeitlichen Grabhügel vom Siedelberg in Oberösterreich. Jahrbuch des Römisch-Germanischen Zentralmuseums 32, 265-322.

EGG, M. 1996a: Zu den Fürstengräbern im Osthallstattkreis. In: JeREM, E. - Lippert, A. (Eds.): Die Osthallstattkultur. Akten des Internationalen Symposiums, Sopron, 10.-14. Mai 1994. Budapest, 53-86.

EGG, M. 1996b: Einige Bemerkungen zum hallstattzeitlichen Wagengrab von Somlóvásárhely, Kom. Veszprém in Westungarn. Jahrbuch des Römisch-Germanischen Zentralmuseums 43, 327-354.

EgG, M. - Kramer, D. (Eds.) 2013: Die hallstattzeitlichen Fürstengräber von Kleinklein in der Steiermark: der Kröllkogel. Monografien des Römisch-Germanischen Zentralmuseums 110. Mainz.

Eibner-Persy, A. 1980: Hallstattzeitliche Grabhügel von Sopron (Ödenburg). Die Funde der Grabungen 1890-92. in der Prähistorischen Abteilung des Naturhistorischen Museums in Wien und im Burgenländischen Landesmuseums in Eisenstadt. Wissenschaftliche Arbeiten aus dem Burgenland 62. Eisenstadt.

Éri, I. - Kelemen, M. - Németh, P. - Torma, I. 1969: Veszprém megye régészeti topográfiája. A veszprémi járás. Magyarország Régészeti Topográfiája 2. Budapest.

Figler, A. 1985: Győrszemere-Tót-tag. Régészeti Füzetek I/38, 12-13.

FigLer, A. 2010: Hallstatt-kori halomsírok Nagybarátin (Hallstatt Age Tumuli in Nagybaráti, Győrújbarát). Arrabona 48/2, 7-48.

FeKete, M. 1985: Rettungsgrabung früheisenzeitlicher Hügelgräber in Vaskeresztes. Acta Archaeologica Acadaemiae Scientiarum Hungaricae 37, 33-78.

Fontijn, D. - VAn DER VAART, S. - JANSEn, R 2013: Transformation through destruction. A monumental and extraordinary Early Iron Age Hallstatt C barrow from the ritual landscape of Oss-Zevenbergen. Leiden.

Gallus, S. - HoRváth, T. 1939: A legrégibb lovasnép Magyarországon. A korai vaskorból való régészeti hagyatéka és eurázsiai kapcsolatai (Un peuple cavalier préscythique en Hongrie. trouvailles archéologiques du premier âge du fer et leurs relations avec l'Eurasie). Dissertationes Pannonicae 2/9. Budapest.

GÁL, K. - Molnár, A. 2004: Sé-Doberdó, az 1998-es ásatások vaskori leletanyaga. Savaria 28, 159-230.

GÁtı, Cs. 2009: A szajki (Baranya megye) koravaskori telep kulturális kapcsolatai (Cultural contacts of the Early Iron Age settlement at Szajk, Baranya County). In: ILON G. (Ed.): $M \Omega M O \Sigma$ VI. Öskoros Kutatók VI. Összejövetelének konferenciakötete - Nyersanyagok és kereskedelem, Köszeg, 2009. március 19-21. Szombathely, 65-77.

Gleirscher, P. 2001: Norische Könige - Historische Quellen und archäologischer Befund. Prähistorische Zeitschrift 76, 87-104.

Gleirscher, P. 2005a: Hügelgräber und Herrschaftsbereiche im Ostalpenraum. Arheološki Vestnik 56 (2005) 99-112.

GLEIRSCher, P. 2005b: Das Grab eines namenlosen Königs in Waisenberg. In: Wedenig, R. (Ed.): Hallstattkultur im Trixnertal. Klagenfurt, 58-79.

Griebl, M. 1997: Siedlungsobjekte der Hallstattkultur aus Horn (Niederösterreich). Notbergungen auf dem Gelände der Ziegelei Thalhammer und den benachbarten Flächen in den Jahren 1888/89 bis 1976. Mitteilungen der Prähistorischen Komission 31. Wien.

GrIEBl, M. 2004: Die Siedlung der Hallstattkultur von Göttlesbrunn, Niederösterreich. Rettungsgrabungen im Zuge des Ostautobahnbaus (A 4) im fahre 1989. Mitteilungen der Prähistorischen Kommission 54 . Wien. 
Groma, K. 2015: Das Gräberfeld aus der Früheisenzeit bei Tatabánya-Alsó vasútállomás (Ungarn). In: Szathmáry, I. (Ed.): An der Grenze der Bronze- und Eisenzeit: Festschrift für Tibor Kemenczei zum 75. Geburtstag. Budapest, 137-166.

Gutjahr, Сн. 2015a: Eine ausgewählte Fundstelle: Das spätbronze- und frühhallstattzeitliche Brandgräberfeld in Kainach bei Wildon. In: HEBERT, B. (Ed.): Urgeschichte und Römerzeit in der Steiermark. Geschichte der Steiermark 1.Wien, 427-430.

Gutjahr, Сн. 2015b: Das Grab 3 aus dem spätbronze-und frühhallstattzeitlichen Gräberfeld von Kainach bei Wildon, Gem. Weitendorf, Stmk. In: Gutjahr, CH. - Tiefengraber, G. (Eds.): Beiträge zur Hallstattzeit am Rande der Südostalpen, Akten des 2. Wildoner Fachgespräches am 10. und 11. Juni 2010 in Wildon/Stmk. Rahden/Westf. 2015, 173-194.

HACK, S. 2002: Der Wiesenkaisertumulus Nr. 4, eine hallstattzeitliche bestattung in Goldes, Steiermark. Fundberichte aus Österreich 41, 91-166.

HAMPEL, U. 2005: Hallstattzeitliche und provinzialrömische Funde der Feststellungsgrabung 1991/92 im Gräberfeld von Leibnitz-Altenmarkt, Steiermark. Fundberichte aus Österreich 44, 223-280.

Hansen, L. 2007: Das Panzergrab im Tschoneggerfranzl-Tumulus 2 bei Kleinklein (Gem. Großklein, Bez. Leibnitz) in der Weststeiermark. Jahrbuch des Römisch-Germanischen Zentralmuseums 54/1, 173-215.

Havasi, B. - BusznYÁk, J. 2008: A zalaszántói őskori tumulusok felmérésének legújabb eredményei (The most recent results of the measuring of the prehistoric tumuli at Zalaszántó). Zalai Múzeum 17, 93-102.

Heger, F. 1879: Der Tumulus bei Pillichsdorf in Niederösterreich. Mitteilungen der Anthropologischen Gesellschaft 9, 229-243.

Heger, F. 1887: Bericht über die in den Jahren 1877 und 1878 von dem K. K. Naturhistorischen Hofmuseum am Salzberge und am Hallberge bei Hallstatt ausgeführten Ausgrabungen. Mitteilungen der Prähistorischen Komission 1, 33-40.

Hellerschmid, I. 2006: Die urnenfelder-/hallstattzeitliche Wallanlage von Stillfried an der March. Ergebnisse der Ausgrabungen 1969-1989 unter besonderer Berücksichtigung des Kulturwandels an der Epochengrenze Urnenfelder-/Hallstattkultur. Mitteilungen der Prähistorischen Komission 63. Wien.

Holl, B. - CzAJLik, Z. 2013: Where are all the tumuli? Problems of interpretation in aerial archaeology. In: Czajlik Z. - BöDőcs A. (eds.): Aerial Archaeology and Remote Sensing from the Baltic to the Adriatic. Selected Papers of the Annual Conference of the AARG, 2012. Budapest, 25-31.

HolporT, Á. 1985: Ásatások Százhalombattán 1978-82 (Előzetes jelentés) (Ausgrabungen in Százhalombatta 1978-1982, Vorläufiger Bericht). Studia Comitatensia - Múvészettörténeti Tanulmányok Pest Megyéből 17 (1985) 25-62.

Holport, Á. 1986: Questions in connection with recent excavations at Százhalombatta. In: Török L. (Ed.): Hallstatt Kolloquium Veszprém, 1984. Budapest, 93-98.

Holport, Á. 1993: Kora vaskori halomsíros temető Érd-Százhalombatta határában. In: Poroszlai I. (Ed.): 4000 év a 100 halom városában - Fejezetek Százhalombatta történetéből. Százhalombatta, 23-32.

Holport, Á. 1996: Építészeti emlékek az Érd-százhalombattai kora vaskori halomsíros temetőből (Architectural remains in the Tumulus cemetery of Százhalombatta). In: PoroszlaI, I. (Ed.): Ásatások Százhalombattán 1989-1995 (Excavations at Százhalombatta 1989-1995). Százhalombatta, 34-42.

Hontr, Sz. 1993: Angaben zur Geschichte der Urnenfelder-Kultur in Südwest-Transdanubien. Pavúk, J. (Ed.): Actes du 12e Congrès International des Sciences Préhistoriques et Protohistoriques, Bratislava, 1-7 septembre 1991. 3. Bratislava, 147-155.

HoRváth, A. 1969: A vaszari és somlóvásárhelyi Hallstatt-kori halomsírok (Hügelgräber aus der Hallstattzeit nächst Somlóvásárhely und Vaszar). Veszprém Megyei Múzeumi Közlemények 8, 109-134.

HorvÁth, L. 2012: Kora vaskori település Letenyén (An Early Iron Age settlement at Letenye). Zalai Múzeum 20, 111-158. 
HoRváth, L. 2014: Early Iron Age graves from Keszthely and its environs (Data publication). In: HeInRich-TAmÁska, O. - Straub, P. (Eds.): Mensch, Siedlung und Landschaft im Wechsel der Jahrtausende am Balaton (People, settlement and landscape on Lake Balaton over the millenia). Castellum Pannonicum Pelsonense 4. Budapest - Leipzig - Keszthely - Rahden, 63-97.

Hvala, S. T. - Dular, J. - Kocuvan, E. 2004: Zeleznodobne gomile na Magdalenski gori (Eisenzeitliche Grabhügel auf der Magdalenske gora). Katalogi in Monografije 36. Ljubljana.

Ilon, G. 1992: A nagydémi Középrépáspuszta évszázadai. Pápa.

ILON, G. 2001: Siedlungswesen und Bestattungssitten in Gór. Zum Übergang von der Urnenfelder- zur Hallstattzeit. In: Lippert, A. (Ed.): Die Drau-, Mur- und Raab-Region im 1. vorchristlichen fahrtausend. Akten d. Internat. u. Interdisziplinären Symposiums vom 26. bis 29. April 2000 in Bad Radkersburg. Universitätsforschungen zur prähistorischen Archäologie 78. Bonn, 243-267.

ILON, G. 2004: Szombathely őskori településtörténetének vázlata - avagy a római kor elött is volt élet (Outline of the pre-historic settlement of Szombathely, or life before the Roman Age). Szombathely.

Ilon, G. - SÜmegi, P. - Tóth, G. - NÁfrádi, K. - Persaits, G. - PÁll, D. G. - Törő́csik, T. - Nyerges, É. - MinÁly, J. - SÁndor-KovÁcs, J. - RAdics, A. - Udvardi, B. 2011: Szombathely-Zanat késő urnamezős korú temetője és a lelőhely más ős- és középkori emlékei természettudományos vizsgálatokkal kiegészitett anyagközlése (The Late Urnfield Period Cemetery from Szombathely-Zanat supplemented by an assessment of prehistoric and medieval settlement features and interdisciplinary analyses). VIA - Kulturális Örökségvédelmi Kismonográfiák 2. Budapest.

JÁKy, A. 2016: Kora vaskori teleprészlet Balatonboglár-Berekre-dűlőből. Communicationes Archaeologicae Hungariae 2015-2016, 147-172.

Jerem, E. 1968: The Late Iron Age Cemetery of Szentlőrinc. Acta Archaeologica Acadaemiae Scientiarum Hungaricae 20, 159-208.

KabAy M., É. 1960: A szalacskai koravaskori tumulusok anyaga a Magyar Nemzeti Múzeumban (Das Fundmaterial der früheisenzeitlichen Hügelgräber von Szalacska im ungarischen Nationalmuseum). Folia Archaeologia 12, 45-59.

Kalicz-Schreiber, R. - Kalicz, N. - VÁczi, G. 2010: Ein Gräberfeld der Spätbronzezeit von Budapest-Békásmegyer. Budapest.

Kaus, M. 1984: Das Gräberfeld der jüngeren Urnenfelderzeit von Stillfried an der March. Ergebnisse der Ausgrabung 1975-1977. Forschungen in Stillfried 6. Wien.

Keller, CH. 2015: Die Rekonstruktion sozialer Gruppen der Hallstattzeit zwischen Enns und Donau. Eine statistische Analyse. Berliner Archäologische Forschungen 14. Berlin.

KemenCZEI, T. 1973: Előzetes jelentés a Nagyberki-szalacskai halomásatásokról (Vorläufiger Bericht über die Erschliessung von Hügelgräbern in Nagyberki-Szalacska). Somogyi Múzeumi Közlemények 1, 329-333.

KemenczeI, T. 1974: Újabb leletek a Nagyberki-szalacskai koravaskori halomsírokból (Neuere Funde aus den früheisenzeitlichen Hügelgräbern von Nagyberki-Szalacska). Archaeologiai Értesitó 101, 3-16.

Kemenczei, T. 1975: Beszámoló a Nagyberki-szalacskai 1974. évi ásatásról. Somogyi Múzeumi Közlemények 2, 163-171.

Kemenczei, T. 1976: Früheisenzeitliche Keramikfunde von Nagyberki. Folia Archaeologia 27, 203-208.

Kemenczei, T. 1977: Hallstattzeitliche Funde aus der Donaukniegegend. Folia Archaeologia 28, 67-90.

KemenczeI, T. 1989: Koravaskori sírleletek az Alföldről az Őskori Gyüjteményben (Grabfunde der Früheisenzeit von der Tiefebene in der Prähistorischen Sammlung). Folia Archaeologia 40, 55-74.

KIss, V. 2012: Middle Bronze Age encrusted pottery in Western Hungary. Varia Archaeologica Hungarica 27. Budapest.

Klemm, S. 1996: Zum Verhältnis Höhensiedlung-Gräberfeld im Spiegel der hallstattzeitlichen Funde am Alpenostrand, dargestellt am Beispiel der Malleiten bei Bad Fischau/ NÖ. In: Jerem, E. - Lippert, A. (Eds.): Die Osthallstattkultur. Akten des Internationalen Symposiums, Sopron, 10.-14. Mai 1994. Budapest, 187-208.

KomA, Zs. - ZLINSZKY, A. 2014: DTM generation using land cover classification based on low density lidar data. Geophysical Research Abstracts 16. (http://adsabs.harvard.edu/abs/2014EGUGA. $16.9397 \mathrm{~K})$ 
KovAČEvić, S. 2009: Torčec-Međuriče - prilog poznavanju materijalne kulture halštatskih naselja u koprivničkoj Podravini (Torčec-Međuriče - a Contribution to the Understanding of the Material Culture of the Hallstatt Settlements in the Podravina Region around Koprivnica). Prilozi Instituta za arheologiju u Zagrebu 26, 45-78.

KősZEGi, F. 1988: A Dunántúl története a későbronzkorban. BTM Mủhely 1. Budapest.

Kramer, M. 1996: Zum Beginn der Hallstattkultur in der Steiermark. In: Jerem, E. - Lippert, A. (Eds.): Die Osthallstattkultur. Akten des Internationalen Symposiums, Sopron, 10.-14. Mai 1994. Budapest, 209-220.

Kramer, M. 2015: Das Gräberfeld bei der Hauptschule in Wildon. In: Gutjahr, Ch. - Tiefengraber, G. (Eds.): Beiträge zur Hallstattzeit am Rande der Südostalpen, Akten des 2. Wildoner Fachgespräches am 10. und 11. Juni 2010 in Wildon/Stmk. Rahden/Westf. 2015, 195-210.

Kreiter, A. - Czifra, Sz. - Bendő, Zs. - Jánosné, I. E. - PÁnczÉL, P. - VÁczi, G. 2014: Shine like metal: an experimental approach to understand prehistoric graphite coated pottery technology. Journal of Archaeological Science 52, 129-142.

Kromer, K. - Pescheck, Сн. 1957: Die hallstättischen Grabhügel in Niederösterreich und im Burgenland. Mitteilungen der Anthropologischen Gesellschaft 87, 53-66.

KulcsÁr, G. 2007: Ordacsehi-Kis-töltés. In: BelÉNyesy K. - Hontr Sz. - KIss V. (Eds.): Gördülő idő. Régészeti feltárások az M7-es autópálya Somogy megyei szakaszán Zamárdi és Ordacsehi között. Budapest, 185-192.

Kuzsinszky, B. 1920: A Balaton környékének archaeologiája. Budapest 1920.

Lagia, A. - Papathanasiou, A. - Malakasioti, Z. -Tsiouka, F. 2013: Cremations of the Early Iron Age from Mound 36 at Voulokalyva (ancient Halos) in Thessaly: a bioarchaeological appraisal. In: Lochner, M. - Ruppenstein, F. (Eds.): Brandbestattungen von der mittleren Donau bis zur Ägäis zwischen 1300 und 750 v. Chr. Mitteilungen der Prähistorischen Komission 77. Wien, 197-220.

LÁzÁR, J. 1951: A sághegykörnyéki hallstattkori tumulus-sírokról (Tumulus graves belonging to the Hallstatt period from the surroundings of Sághegy). Archaeologiai Értesitő 78/1, 36-42.

LÁzÁr, J. 1955: Hallstatt-kori tumulusok a Ság-hegy távolabbi környékéről (Hallstattzeitliche Tumuli aus der weiteren Umgebung des Ságberges, Westungarn). Archaeologiai Értesitó 82, 202-211.

LeHner, M. 1996: Die Archäologie des Leechhügels. In: Forschungen zur Leechkirche in Graz. Fundberichte aus Österreich Materialheft A/4. Wien, 19-156.

LENGyeL, I. 1959: A halimbai (Veszprém megye) koravaskori temető (La Cimetière du premier Âge du Fer de Halimba). Archaeologiai Értesítő 86, 159-169.

Lipp, V. 1884: A keszthelyi sírmezők. Budapest.

LipPert, A. 2008: Hallstattzeitliche Grabhügel auf dem Slazkogel in Paldau, Steiermark. Archaeologia Austriaca 92, 73-131.

Lochner, M. 1988: Ein Flachgräberfeld der Hallstattkultur in Grafenwörth, pol. Bez. Tulln, Niederösterreich. Archaeologia Austriaca 72, 91-142.

LochNeR, M. 1991: Studien zur Urnenfelderkultur im Waldviertel (Niederösterreich). Mitteilungen der Prähistorischen Kommission 25. Wien.

Luczenbacher, J. 1847: A’ pogány magyar sírok. Magyar Academiai Értesítő VII/9, 282-290.

MarÁz, B. 1996: Pécs-Jakabhegy - Ausgrabungsergebnisse und die Fragen der Frühhallstattkultur in Südpannonien. In: Jerem, E. - Lippert, A. (Eds.): Die Osthallstattkultur. Akten des Internationalen Symposiums, Sopron, 10.-14. Mai 1994. Budapest, 255-265.

Marton, E. - Regenye, J. 2005: A Fortified Site from the Late Bronze-Late Iron Age at Lake Balaton in Tihany-Óvár: A Rescue Excavation in Hungary, May 2000. In: Congrès UISPP (14e), Université de Liège, Belgique, 2-8 septembre 2001. Section 12: Âge du Fer en Europe / The Iron Age in Europe. British Archaeological Reports International Series 1378. Oxford, 45-52.

D. MAtuz, E. 2000: A Szeged-Algyő 258. kútkörzet területén feltárt preszkíta temető (Das präskythische Gräberfeld im Brunnenbezirk 258 von Szeged-Algyő). A Móra Ferenc Múzeum Évkönyve - Studia Archaeologica 6, 139-164.

Márton, L. 1933: A korai La Tene-kultúra Magyarországon (Die Frühlatenezeit in Ungarn). Archaeologia Hungarica 11. Budapest. 
MCKINLEY, J. I. 1994: A pyre and grave goods in British cremation burials; have we missed something? Antiquity 68/1, 132-134.

McKinley, J. I. 1997: Bronze Age 'Barrows' and Funerary Rites and Rituals of Cremation. Proceedings of the Prehistoric Society 63, 129-145.

McKinley, J. I. 2013: Cremation: Excavation, Analysis, and Interpretation of Material from Cremation-Related Contexts. In: TArLow, S. - Nilsson Stutz, L. (Eds.): The Oxford Handbook of the Archaeology of Death and Burial. Oxford, 47-172.

MEDARIĆ, I. - Mušić, B. - ČrEŠNAR, M. 2016: Tracing flat cramation graves using integrated advanced processing of magnetometry data. In: Armit, I. - PotrebicA, H. - Črešnar, M. - Philip, M. Büster, L. (eds.): Cultural Encounters in Iron Age Europe. Budapest, 67-94.

MetZner-Nebelsick, C. 2002: Der „Thrako-Kimmerische“ Formenkreis aus der Sicht der Urnenfelderund Hallstattzeit im südöstlichen Pannonien. Vorgeschichtliche Forschungen 23. Leidorf.

Mrthay S. 1980: A vaszari koravaskori temető és telephely (Gräberfeld und Siedlung von Vaszar aus der Früheisenzeit). Archaeologiai Értesító 107, 53-78.

Mitнay S. 1983: Koravaskori temetkezés Lovászpatona-Kishalmon (Früheisenzeitliche Bestattung in Lovászpatona-Kishalom). Communicationes Archaeologicae Hungariae 3, 55-62.

Molnár A. 2006: Hallstatt-kori temető Hegyfalu határából (Das hallstattzeitliche Gräberfeld von Hegyfalu). Savaria 30, 199-230.

MoosleitneR, F. 1996: Zum Übergang von der Urnenfelderzeit zur Hallstattperiode im Salzburger Becken. In: Jerem, E. - Lippert, A. (Eds.): Die Osthallstattkultur. Akten des Internationalen Symposiums, Sopron, 10.-14. Mai 1994. Budapest, 315-326.

MüLlER, S. 2007: Das hallstattzeitliche Gräberfeld von Vrádište (Untersuchungen zur Grabausstattung und Beigabenstrukturierung). In: BLEČIć, M. ET AL. (Eds.): Scripta praehistorica in honorem Biba Teržan. Ljubljana 2007, 623-642.

MÜLLER, S. 2012a: Monumente der Ahnenverehrung? Zur Deutung der hallstattzeitlichen Grabhügel von Nové Kosarišká. Slovenská Archeológia 60, 343-363.

Müller, S. 2012b: Smolenice-Molpír, Sered' und Ratkovce: Studien zu Siedlungen der frühen Eisenzeit in der Südwestslowakei. Universitätsforschungen zur prähistorischen Archäologie 220. Bonn.

NAGY L. 1939: A középrépáspusztai (Veszprém megye) kora-vaskori temető (Das früheisenzeitliche Gräberfeld von Puszta Középrépás (Komitat Veszprém)). Folia Archaeologica 1, 39-57.

NeBELsick, L. D. 1994: Der Übergang von der Urnenfelder- zur Hallstattzeit am nördlichen Ostalpenrand und im nördlichen Transdanubien. In: Schauer, P. (Ed.): Archäologische Untersuchungen zum Übergang von der Bronze- zur Eisenzeit zwischen Nordsee und Kaukasus: Ergebnisse einses Kolloquiums in Regensburg, 28.-30. Oktober 1992. Regensburg, 307-364.

Nebelsick, L. D. 1997a: Die Kalenderberggruppe der Hallstattzeit am Nordostalpenrand. In: NeBeLsick, L. D. - Lauermann, E. - Eibner, A. (Eds.): Hallstattkultur im Osten Österreichs. Wissenschaftliche Schriftenreihe Niederösterreich 106-109. St. Pölten - Wien, 9-128.

Nebelsick, L. D. 1997b: Trunk und Transzendenz: Trinkgeschirr im Grab zwischen der frühen Urnenfelder- und späten Hallstattzeit im Karpatenbecken. In: Becker, C. - Dunkelmann, M.-L. Metzner-Nebelsick, C. (Eds.): Chronos: Beiträge zur prähistorischen Archäologie zwischen Nord- und Südosteuropa; Festschrift für Bernhard Hänsel. Internationale Archäologie - Studia honoraria 1. Leidorf, 373-387.

Nebelsick, L. D. 2000: Drinking against Death. Drinking Sets in Ostentatious Tombs in the Late Bronze and Early Iron Ages in the Western Carpathian Basin. Altorientalische Forschungen 27, 211-241.

Neogrády, S. 1950: A légi fénykép és az archeológiai kutatások. Térképészeti Közlemények 7, 283-332.

Nováki, Gy. - Uzsoki, A. 1999: Tihany, Óvár őskori földvára. (Prehistoric earthen fort of Tihany, Óvár). Régészeti kutatások Magyarországon 1999, 63-70.

Novinszki-Groma, K. 2017: New data on the burial customs in the Early Iron Age on the Basis of examples from Northeast-Transdanubia. In: HečKovÁ, J. (Ed.): Studia Historica Nitriensia 2017/ Supplementum - mimoriadne číslo časopisu venované životnému jubilee prof. Petra Romsauera: Sedem Decénií Petra Romsauera. Nitra, 155-172.

PARE, CH. F. E. 1992: Wagons and Wagon-Graves of the Early Iron Age in Central Europe. Oxford 1992. 
Parzinger, H. - Stegmann-Rajtár, S. 1988: Smolenice-Molpír und der Beginn skythischer Sachkultur in der Südwestslowakei. Prähistorische Zeitschrift 63, 162-178.

Patek, E. 1968: Die Urnenfelderkultur in Transdanubien. Archaeologia Hungarica 44. Budapest.

PateK, E. 1973: Zalaszántó. Archaeologiai Értesító 100, 261-262.

PAтEK, E. 1974/75: Zalaszántó, Várrét. Mitteilungen des Archäologischen Instituts der Ungarischen Akademie der Wissenschaften 5, 206-207.

Patek, E. 1982a: Neue Untersuchungen auf dem Burgstall bei Sopron. Bericht der Römisch-Germanischen Komission 63, 105-179.

PATEK, E. 1982b: Recent excavations at the Hallstatt and La Tène hill-fort of Sopron-Várhely (Burgstall) and the predecessors of the Hallstatt culture in Hungary. In: GABleR, D. - PATEK, E - VöRös, I. (Eds.): Studies in the Iron Age of Hungary. British Archaeological Reports International Series 144. Oxford, 1-56.

PATEK, E. 1982/83: Die nordosttransdanubische Hallstattgruppe: ein Überblick. Mitteilungen des Archäologischen Instituts der Ungarischen Akademie der Wissenschaften 12/13, 59-84.

PAтEK, E. 1990: A Szabó János Győző által feltárt „preszkíta” síranyag. A Füzesabony-mezőcsát típusú temetkezések újabb emlékei Heves megyében (Die von János Győző Szabó freigelegten „preskythischen“ Grabfunde. Die neuen Denkmäler der Bestattungen des Typs Füzesabony-Mezőcsát im Komitat Heves). Agria Az Egri Múzeum Évkönyve 25/26, 61-118.

Patek, E. 1991: Der Tumulus Nr.177 von Sopron-Burgstall. Acta Archaeologica Acadaemiae Scientiarum Hungaricae 43, 273-298.

PateK, E. 1993: Westungarn in der Hallstattzeit. Qvellen und Forschungen zur Prähistorie und provincialrömische Archäeologie 7. Weinheim.

PAULík, J. 1958: Nové hrobové nálezy z mladšej doby halštatskej na juhozápadnom Slovensku (Neue Grabfunde aus der jüngeren Hallstattzeit in der Slowakei). Slovenská Archeológia 6, 361-379.

Peschecк, СH. 1948: Späthalltättische Kulturströmungen im Ostalpenraum. In: Schwarz, K. (Ed.): Strena Praehistorica - Festgabe zum 60. Geburtstag von Martin Fahn. Halle, 153-182.

Petres, É. - Jungbert, B. 1997: Fehérvárcsurgó - Kora vaskori halomsíros temető. In: Cserményi V. (Ed.): Évezredek kincsei - Régészeti Kiállítások. A Szent István Múzeum Közleményei D. sorozat 244, Székesfehérvár 1997.

Pichlerová, M. 1960: Mladohalštatské popolnicové pohrebisko vo Vrádišti (Junghallstattzeitliches Urnenfeld in Vrádište). Slovenská Archeológia 8/1, 125-167.

Pichlerová, M. 1969: Nové Košariská: kniežacie mohyly zo staršej doby železnej (Nové Košariská: Die fürstlichen Hügelgräber aus der frühen Eisenzeit). Slovenské Národné Múzeum (Bratislava), Historický Odbor, Fontes 3. Bratislava.

Pittioni, R. 1954: Urgeschichte des Österreichischen Raumes. Wien.

Potrebica, H. 2011: Kaptol-Čemernica (istraživanje 2009). Hrvatski arheološki godišnjak 6, 101-105.

Potrebica, H. 2012: Religious Phenomena of the Hallstatt Communities of Southern Pannonia. In: BereczKi, S. (Ed.): Iron Age Rites and Rituals in the Carpathian Basin. Proceedings of the International Colloqium from Targu Mures, 7-9 October 2011. Târgu Mureş, 9-29.

Potrebica, H. - Mavrović Mokos, J. 2016: Encounters on borders of worlds: the Kaptol Group in the Early Iron Age communication network. In: Armit, I. - PotrebicA, H. - ČrešnAR, M. - Philip, M. Büster, L. (Eds.): Cultural Encounters in Iron Age Europe. Budapest, 39-66.

Preinfalk, F. 2003: Die hallstattzeitlichen Hügelgräber von Langenlebarn, Niederösterreich. Fundberichte aus Österreich, Materialhefte A 12. Wien.

Preinfalk, A. 2012: Die hallstattzeitliche Siedlung von Michelstetten. Archäologische Forschungen in Niederösterreich 10. St. Pölten.

Radimský, V. - Szombathy, J. 1885: Urgeschichtliche Forschungen in der Umgegend von Wies in Mittel-Steiermark II. Bericht über die in den Jahren 1881, 1882 und 1883 durchgeführten Grabungen. Mitteilungen der Anthropologischen Gesellschaft 15, 117-168.

Rakvin, M. 2015: Naselje na gradini Marić kod Mikleuške tijekom kasnoga brončanog i starijeg željeznog doba (The Marić Hillfort Settlement near Mikleuška during the Late Bronze and the Early Iron Age). Prilozi Instituta za arheologiju u Zagrebu 32 (2015), 75-110. 
Rebay, K. C. 2002: Die frühhallstattzeitliche Grabhügelgruppe von Zagersdorf. Eisenstadt.

Rebay, K. C. 2006: Das hallstattzeitliche Gräberfeld von Statzendorf in Niederösterreich. Möglichkeiten und Grenzen der Interpretation von Sozialindexberechnungen. Universitätsforschungen zur prähistorischen Archäologie 135. Bonn.

RÉCSEY, V. 1895: Balaton-vidéki régészeti kutatásaim néhány eredménye. Veszprém.

Regenye, J. 2004: Előzetes jelentés a Tihany-Óvárban folytatott feltárásról. In: NAGy, E. Gy. DANI, J. - HAJDÚ, Zs. (Eds.): MQMO乏 II. - Öskoros kutatók II. összejövetelének konferenciakötete. Debrecen, 187-198.

RHÉ, Gy. 1929: A somlóvásárhelyi halomsírok. Évi jelentés a Veszprémvármegyei Múzeum és Múzeumi Könyvtár 1928/29. évi fejlődéséről és évvégi állapotáról 4. Veszprém, 1-10.

Rómer, F. 1878: Congrés International d'Anthropologie et d'Archéologie Préhistorique. Compte-rendu de la huitieme session a Budapest 1876, Second volume I. partie: Résultats généraux du mouvement archéologique en Hongrie 2/1. Budapest.

SAuer, F. 2015: Eisen - Gräber - Trinkgelage. Die Hallstattkultur und das Burgenland. Fundberichte aus Österreich, Materialhefte A 24. Wien.

Schumann, R. 2012: Eine unscheinbare keramische Fremdform aus dem hallstattzeitlichen Grabhügelfeld von Farovške njive bei Otočec. Arheološki Vestnik 63, 37-56.

Schumann, R. 2015: Status und Prestige in der Hallstattkultur; Aspekte sozialer Distinktion in ältereisenzeitlichen Regionalgruppen zwischen Almühl und Save. Münchner Archäologische Forschungen 3. München.

Siegfried-Weiss, A. 1979: Der Ostalpenraum in der Hallstattzeit und seine Beziehungen zum Mittelmeergebiet. Hamburger Beiträge zur Archäologie VI. Hamburg.

ŠımeK, M. 1998: Ein Grabhügel mit Pferdebestattung bei Jalžabet, Kroatien. In: HäNSEL, B. - Machnik, J. (Eds.): Das Karpatenbecken und die osteuropäische Steppe: Nomadenbewegungen und Kulturaustausch in den vorchristlichen Metallzeiten (4000-500 v.Chr.). Prähistorische Archäologie in Südosteuropa 12. Leidorf, 493-510.

ŠimeK, M. 2004: Grupa Martijanec-Kaptol / Martijanec-Kaptol Group / Martijanec-Kaptol-Gruppe. In: BALEn-Letunič, D. (ed.): Ratnici na Razmeđu Istoka i Zapada. Starije željezno doba u kontinentalnoj Hrvatskoj. Zagreb, 79-129.

ŠIMEK, M. 2007: Die Fürstengräber der älteren Eisenzeit in Nordkroatien. In: GALTER, H. - Kramer, D. (Eds.): Der Gräberfund von Kleinklein im europäischen Kontext. Graz, 123-153.

Smolník, R. 1994: Der Burgstallkogel bei Kleinklein II: die Keramik der vorgeschichtlichen Siedlung. Veröffentlichungen des Vorgeschichtlichen Seminars Marburg, Sonderband 9. Marburg 1994.

Sørensen, M. L. - RebAy, K. C. 2005: Interpreting the Body. Burial practices at the Middle Bronze Age cemetery at Pitten, Austria. Archaeologia Austriaca 89, 153-175.

Stegmann-RajtáR, S. 1992a: Grabfunde der älteren Hallstattzeit aus Südmähren. Košice.

Stegmann-RAjtáR, S. 1992b: Spätbronze- und früheisenzeitliche Fundgruppen des mittleren Donaugebietes. Bericht der Römisch-Germanischen Komission 73, 29-180.

STEGMANN-RAJTÁR, S. 2009: Žiarové pohrebisko východohalštatskej a vekerzugskej kultúry v Nových Zámkoch (Das Brandgräberfeld der Osthallstattkultur und der Vekerzug-Kultur in Nové Zámky). Slovenská Archeológia 57/1, 57-116.

STUdENíkovÁ, E. 1994: Záchranný výskum halštatskej mohyly v Novej Dedinke (Rettungsgrabung des hallstattzeitlichen Hügelgrabes in Nová Dedinka). Zborník Slovenského Národného Múzea 88 Archeológia 4, 25-50.

StudENíKovÁ, E. 1995: Halštatská mohyla II v Janíkoch, okres Dunajská Streda (Hallstattzeitlicher Tumulus II in Janíky, Bez. Dunajská Streda). Zborník Slovenského Národného Múzea 89, Archeológia 5, 49-76.

Szabó, G. - Fekete, M. 2014: Pannon tumulus feltárásának előkészítése - Regöly, Strupka-Magyar birtok. A Wosinsky Mór Múzeum Évkönyve 36, 7-158.

Szombathy, J. 1924: Die Tumuli im im Feichtenboden bei Fischau am Steinfeld. Mitteilungen der Anthropologischen Gesellschaft 54, 164-197.

TANkó, K. 2005: "Horn-handled" bowls of the Central Europe Iron Age. In: DobrzańsKa, H - Megaw, 
J. V. S. - Poleska, P. (Eds.): Celts on the Margin: Studies in European Cultural Interaction 7th Century BC - 1st Century AD dedicated to Zenon Woźniak. Kraków, 153-162.

TERŽAN, B. 1986: Zur gesellschaftsstruktur während der älteren Hallstattzeit im Ostalpen-Westpannonischen Gebiet. In: TöRÖK, L. (Ed.): Hallstatt Kolloquium Veszprém, 1984. Budapest, 227-244.

TERžAn, B. 1990: Starejša železna doba na slovenskem Štajerskem (The Early Iron Age in Slovenian Styria). Katalogi in monografija 25. Ljubljana.

TERŽAn, B. 1998: Auswirkungen des skythisch geprägten Kulturkreises auf die hallstattzeitlichen Kulturgruppen Pannoniens und des Ostalpenraumes. In: Hänsel, B. - MachniK, J. (Eds.): Das Karpatenbecken und die osteuropäische Steppe. Prähistorische Archäologie in Südosteuropa 12. Südosteuropa-Schriften 20. Leidorf, 511-560.

Tiefengraber, G. 2005: Untersuchungen zur Urnenfelder- und Hallstattzeit im Grazer Becken. Universitätsforschungen zur prähistorischen Archäologie 124. Bonn.

Tiefengraber, G. - Tiefengraber, S. 2015: Zum Stand der Erforschung hallstattzeitlicher „Zentralsiedlungen" in der Obersteiermark. In: Tiefengraber, G. - Gutjahr, Ch. (Eds.): Beiträge zur Hallstattzeit am Rande der Südostalpen: Akten des 2. Internationalen Symposiums am 10. und 11. Juni 2010 in Wildon (Steiermark/Österreich). Rahden/Westfalen, 217-275.

Tótн, F. M. 2012: Korai szkítakori sírok Dédestapolcsány-Verebce-tető lelőhelyen (Early Scythian Age Graves at the Site of Dédestapolcsány-Verebce-tető, NE Hungary). A Hermann Ottó Múzeum Évkönyve 51 (2012) 63-92.

TomedI, G. 1992: Rettungsgrabungen am hallstattzeitlichen Wiesenkaisertumulus Nr. 4 in Goldes, Steiermark. Ein Vorbericht. Archäologisches Korrespondenzblatt 22/2, 209-218.

Tomedi, G. 1994: Der Übergang von der Bronzezeit zur Eisenzeit am Beispiel von Frög, Tumulus „ $\mathrm{K}^{“}$. In: Schauer, P. (Ed.): Archäologische Untersuchungen zum Übergang von der Bronze- zur Eisenzeit zwischen Nordsee und Kaukasus: Ergebnisse einses Kolloquiums in Regensburg, 28.-30. Oktober 1992. Regensburg, 365-383.

Tomedi, G. 2002: Das hallstattzeitliche Gräberfeld von Frög: die Altgrabungen von 1883 bis 1892. Budapest. TöröK, Gy. 1950: Pécs-jakabhegyi földvár és tumulusok. Archaeologiai Értesitőo 77, 4-9.

Uzsoki, A. 1971a: Tihany. Régészeti Füzetek I/24, 17.

Uzsoki, A. 1971b: Tihany Régészeti Füzetek I/25, 22.

Uzsokı, A. 1986: Über die Höhensiedlung und Hügelgraber von Tihany. In: TöRöк, L. (Ed.): Hallstatt Kolloquium Veszprém, 1984. Budapest, 245-250.

VADÁsz, É. V. 1983: Előzetes jelentés egy koravaskori halomsír feltárásáról Süttőn (Vorbericht über die Erschließung eines früheisenzeitlichen Hügels in Süttő). Communicationes Archaeologicae Hungariae 3 (1983) 19-54.

VADÁsz, É. V. 1986a: Neue früheisenzeitlichen Gräberfunde aus Transdanubien. In: Chropovsky, B. CAplovic, D. - LAmiovÁ-Schmiedlová, M. (Eds.): Urzeitliche und frühhistorische Besiedlung der Ostslowakei in Bezug zu den Nachbargebieten. Nitra, 217-226.

VAdÁsz, É. V. 1986b: Das früheisenzeitliche Gräberfeld von Süttő. In: TöröK, L. (Ed.): Hallstatt Kolloquium Veszprém, 1984. Budapest, 251-258.

VADÁsz. É. V. 1996/97: A Sághegy környéki kora vaskori halomsírok fémmellékletei I (Die Metallbeigaben der früheisenzeitlichen Hügelgräber in der Umgebung des Sághegy I). Savaria 23/3, 23-50.

VAdÁsz, É. V. 1997: Das Hügelgrab von Kismező bei dem Ságberg. Zalai Múzeum 8, 27-38.

VADÁsz, É. V. 2003: Kora vaskori halomsír Tata határában (Früheisenzeitliches Hügelgrab in der Gemarkung von Tata). In: KIsNÉ CSEH, J. (Ed.): Annales Tataienses III. Régészeti adatok Tata történetéhez I. Tata, 89-136.

VejvodA, V. - Mirnik, I. 1971: Istraživanja prehistorijskih tumula u Kaptolu kraj Slavonske Požege (Excavations of Prehistoric Barrows at Kaptol). Vjesnik Arheološkog Muzeja u Zagrebu 3/5, $183-210$.

VÉKony, G. - VADÁsz, É. V. 1982: Régészeti Kutatások a Dunántúlon. Őskori sáncok és halmok Süttőn (A fortified settlement and cemetery of the Early Iron Age at Süttő). A Komárom Megyei Múzeumok és a Fejér Megyei Múzeumok régészeti kiállitásai 2. Süttő.

VIDović, J. 1990: Nekropola tumula kraj sela Dvorišća kod Turčišća u Međimurju (Tumulus Necropolis 
near the village Dvorišće by Turčišće in Međimurje). Arheološka istraživanja u Podravini i Kalničko-Bilogorskoj Regiji. Hrvatsko arheološko društvo 14. Zagreb, 77-87.

Vidović, J. 2003: Pogrebni ritus u grobnim humkama Međimurja: Burial rites at grave mounds in Međimurje (Burial rites at grave mounds in Međimurje). In: Čečuk, B. (Ed.): Arheološka istraživanja u bjelovarsko-bilogorskoj županiji i pogrebni ritusi na teritoriju hrvatske. Znanstveni skup. Bjelovar, 25.-27. rujna 1996. Zagreb, 79-86.

VINSKI-GASPARINI, K. 1961: Iskopavanje kneževskog tumula kod Martijanca u Podravini (Ausgrabung eines hallstaättischen Grabhügels bei Martijanec in Draugebiet). Vjesnik Arheološkog Muzeja u Zagrebu 3/2, 39-66.

WedENIG, R. 1997: Erste Ausgrabungen im hallstattzeitlichen Gräberfeld von Führholz in Kärnten. In: Hainzmann, H. (Eds.): Corolla memoriae Walter Modrijan dedicata. Graz, 117-133.

Wosinszky, M. 1896: Tolnavármegye az őskortól a honfoglalásig. Tolnavármegye története 1. Budapest. 


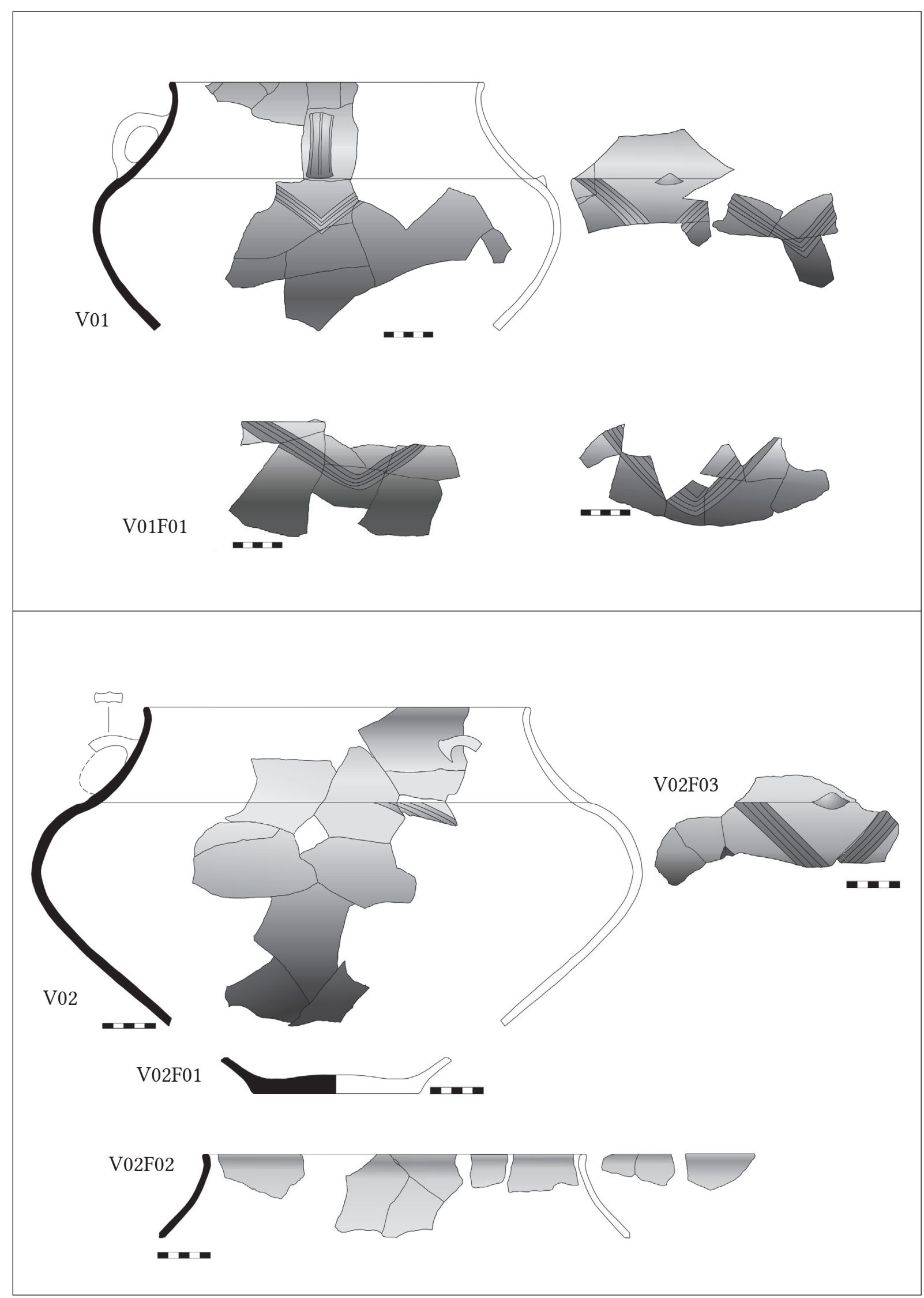

Fig. 19. Potteries of Tumulus 1. 


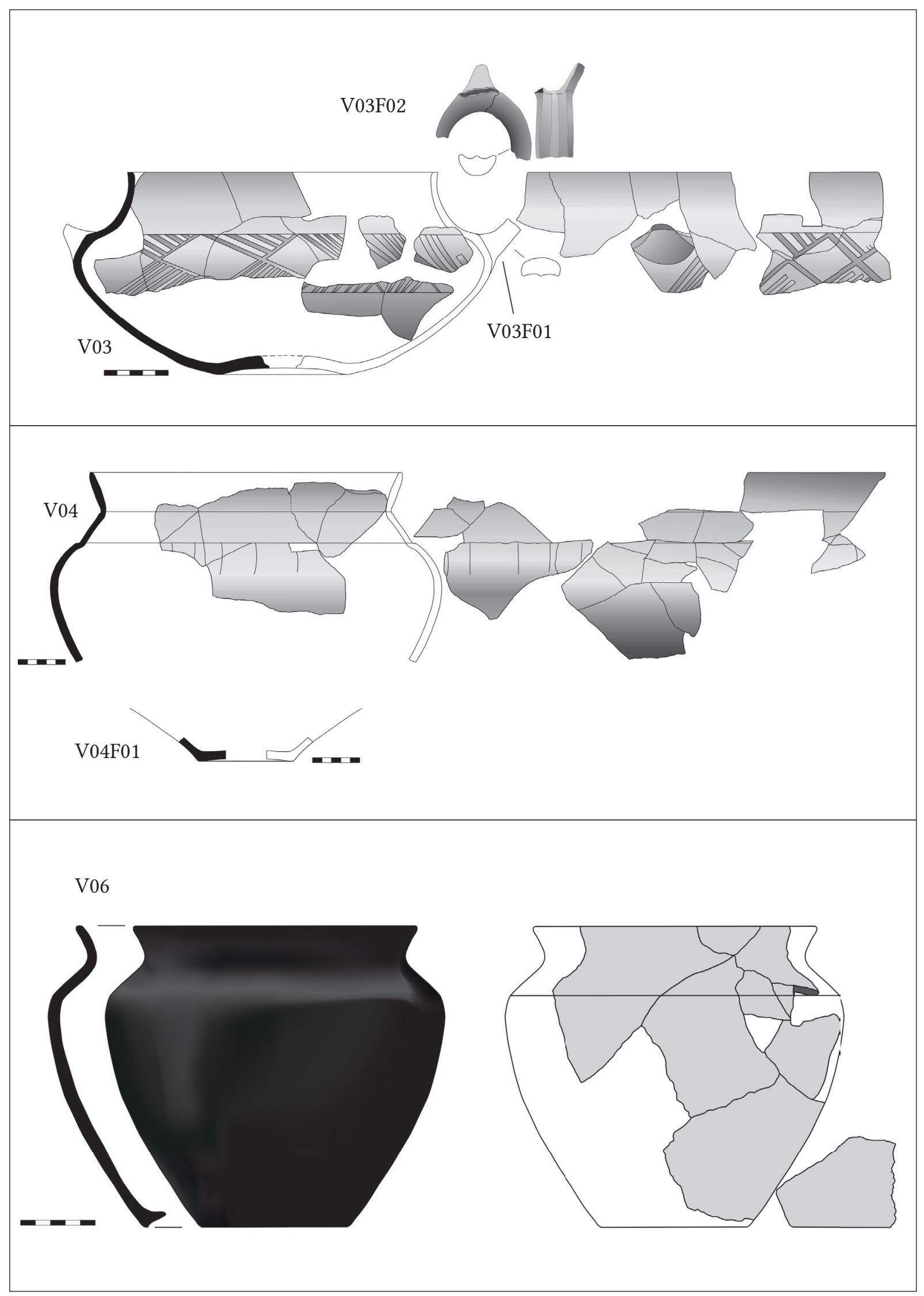

Fig. 20. Potteries of Tumulus 1. 


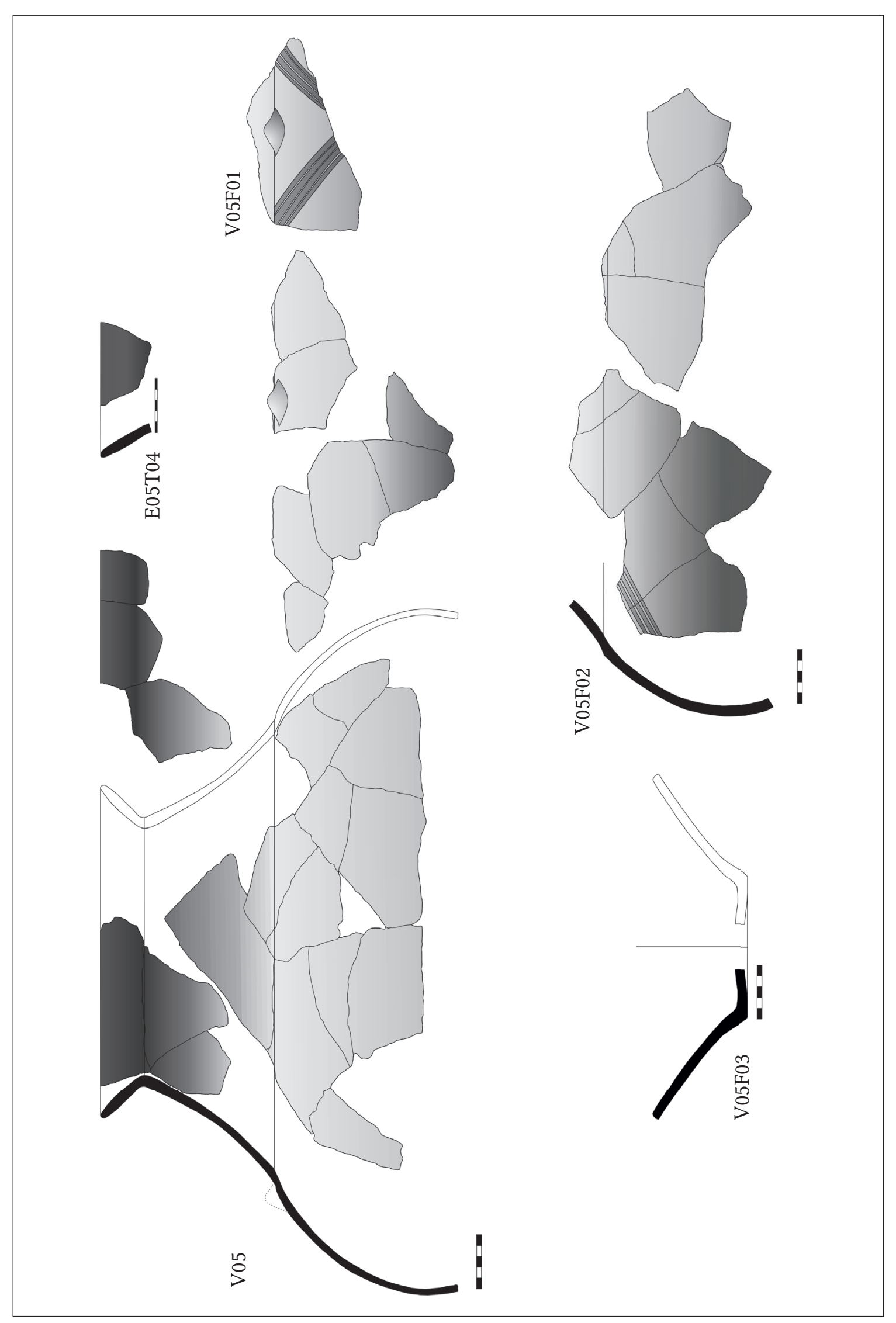

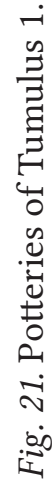




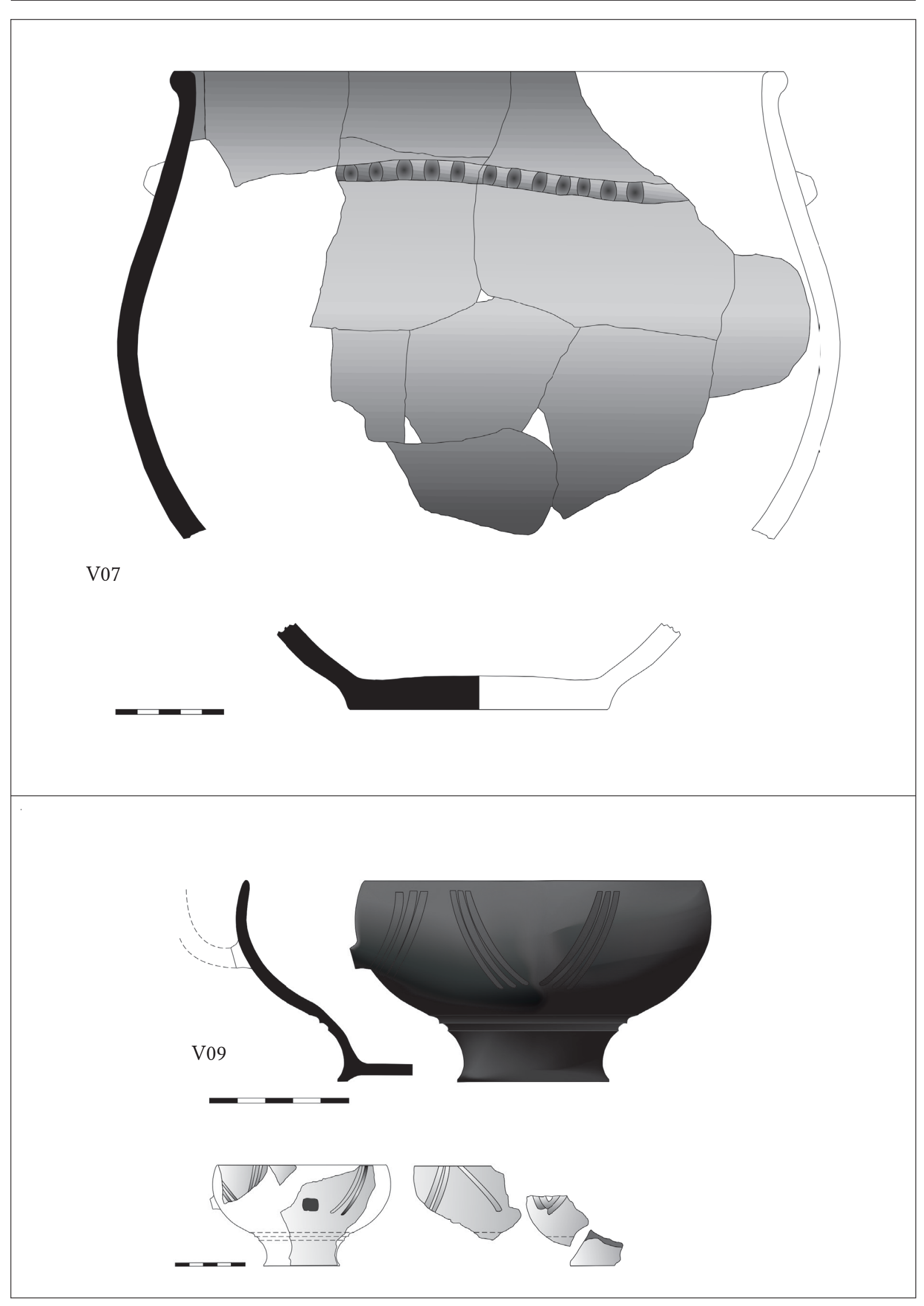

Fig. 22. Potteries of Tumulus 1. 


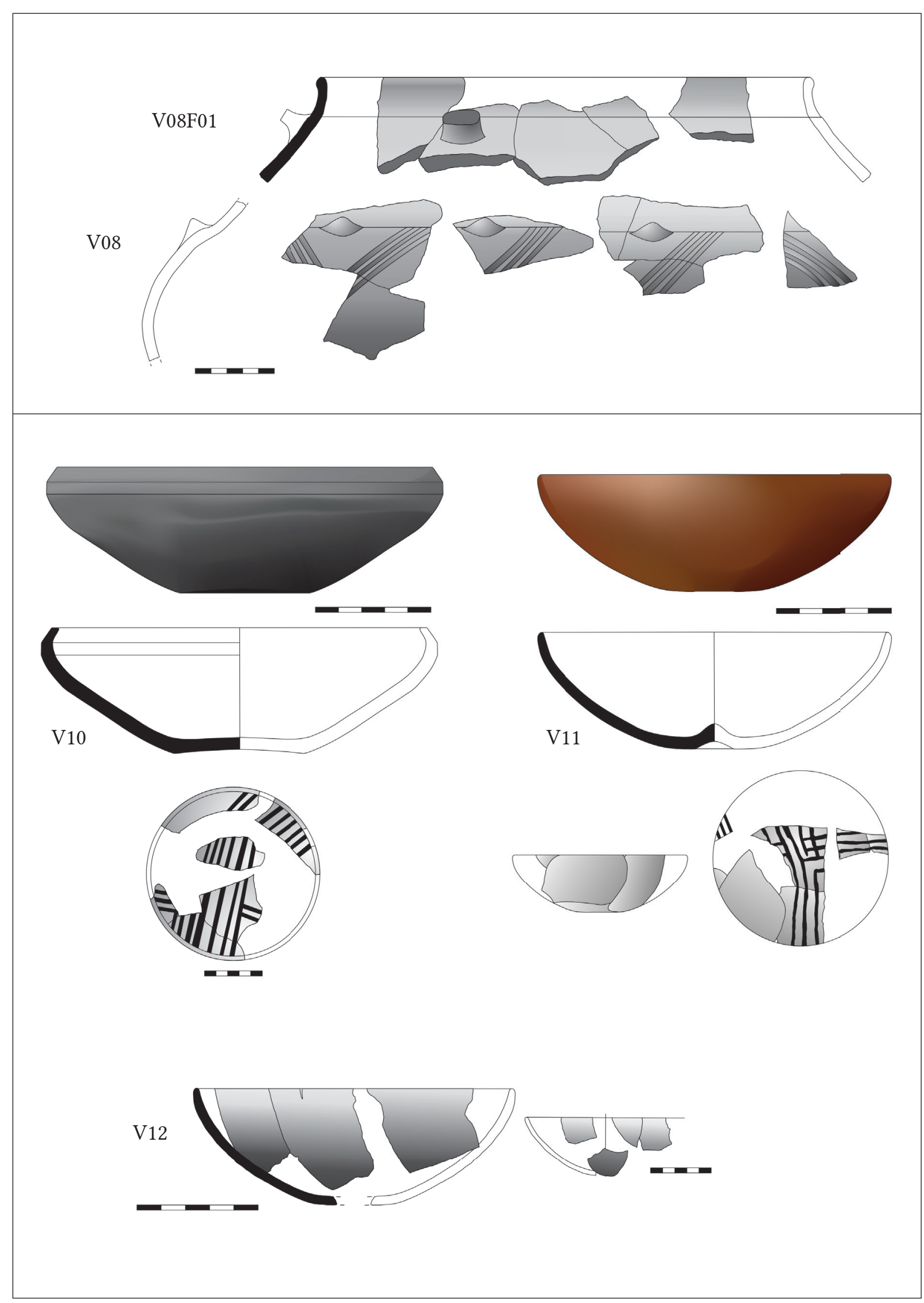

Fig. 23. Potteries of Tumulus 1. 


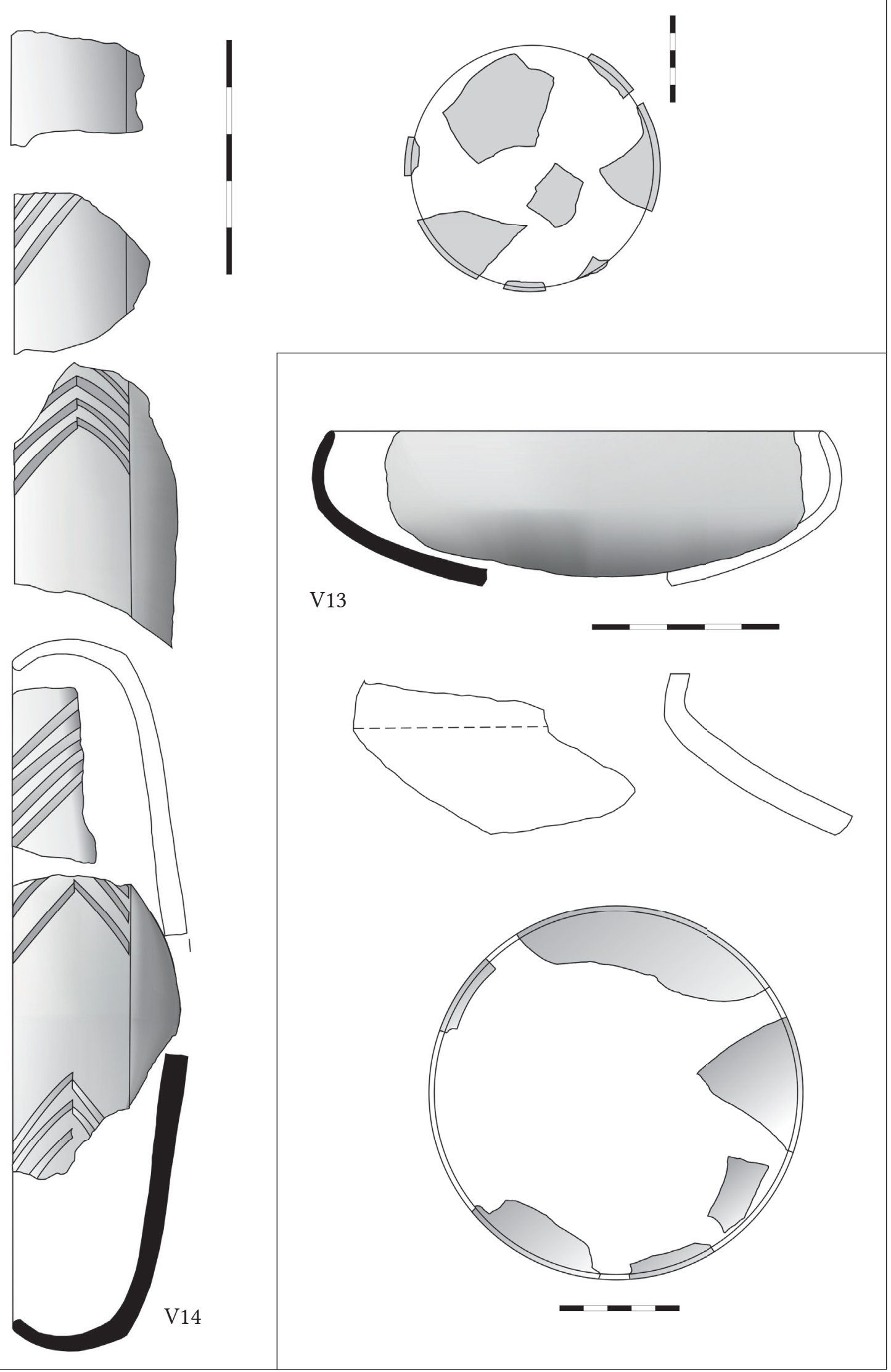

Fig. 24. Potteries of Tumulus 1. 


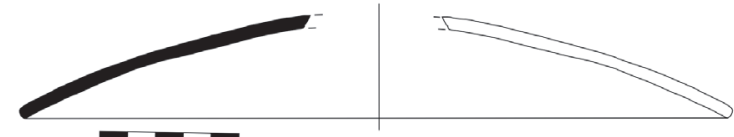

V16
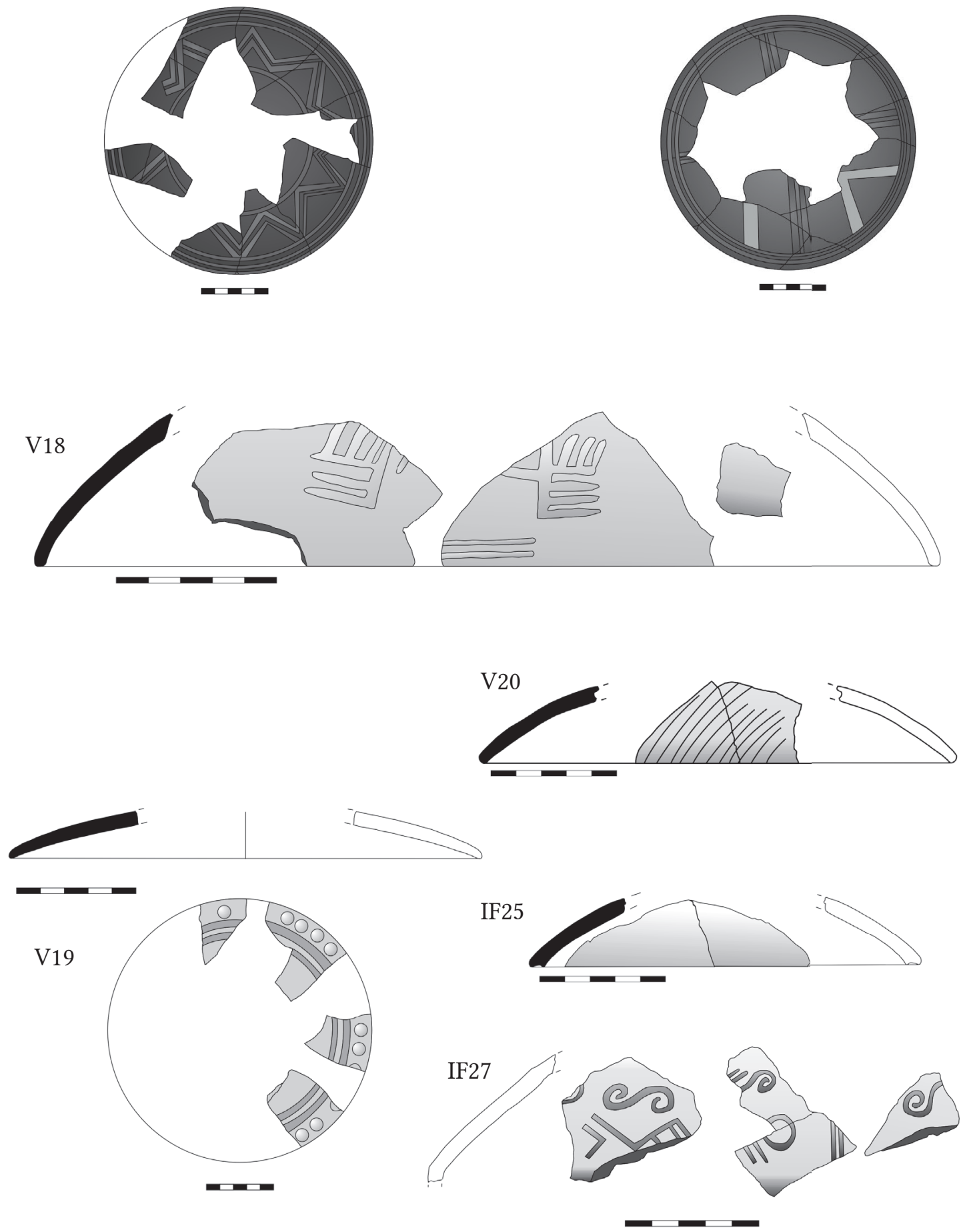

Fig. 25. Potteries of Tumulus 1. 


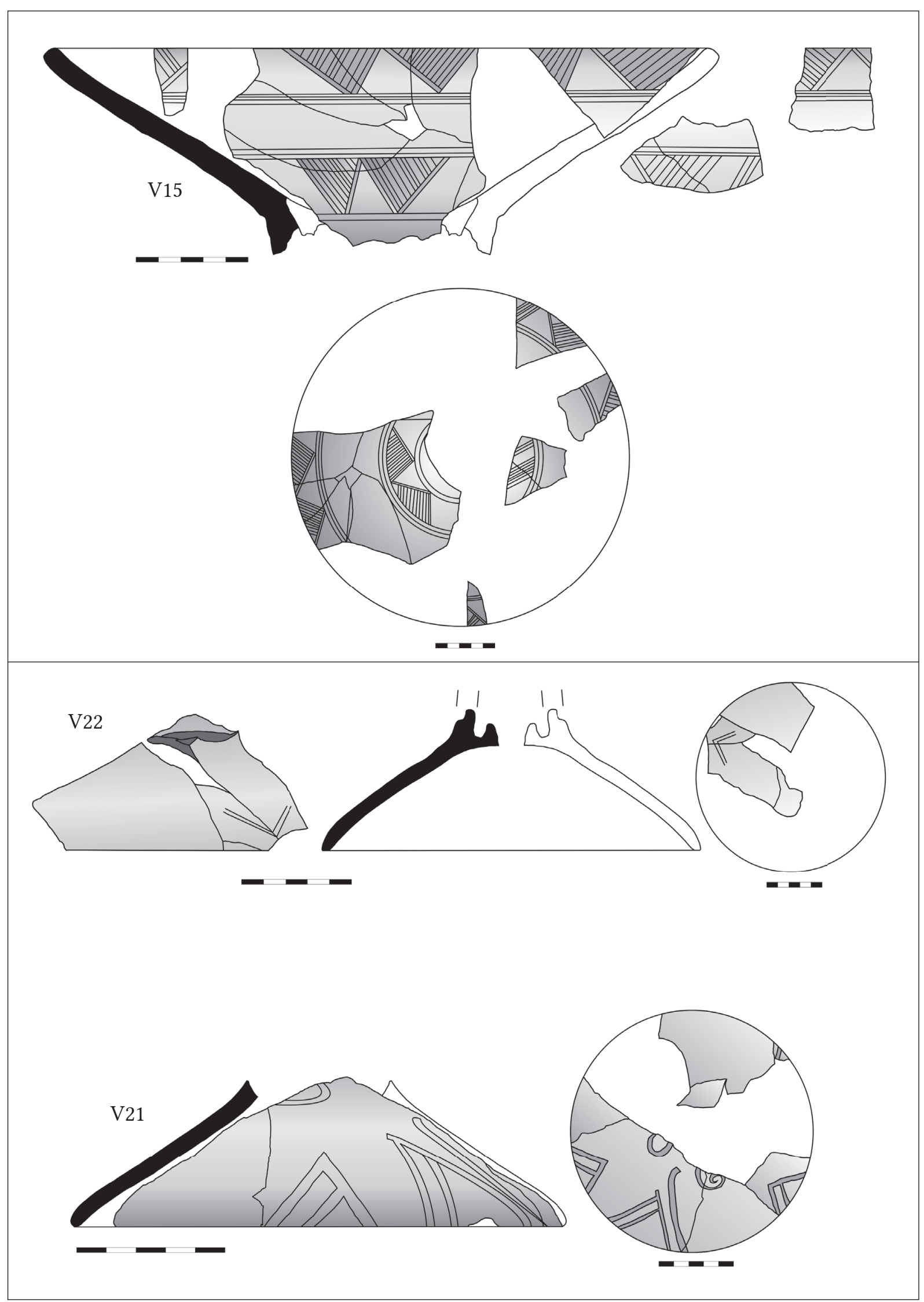

Fig. 26. Potteries of Tumulus 1. 


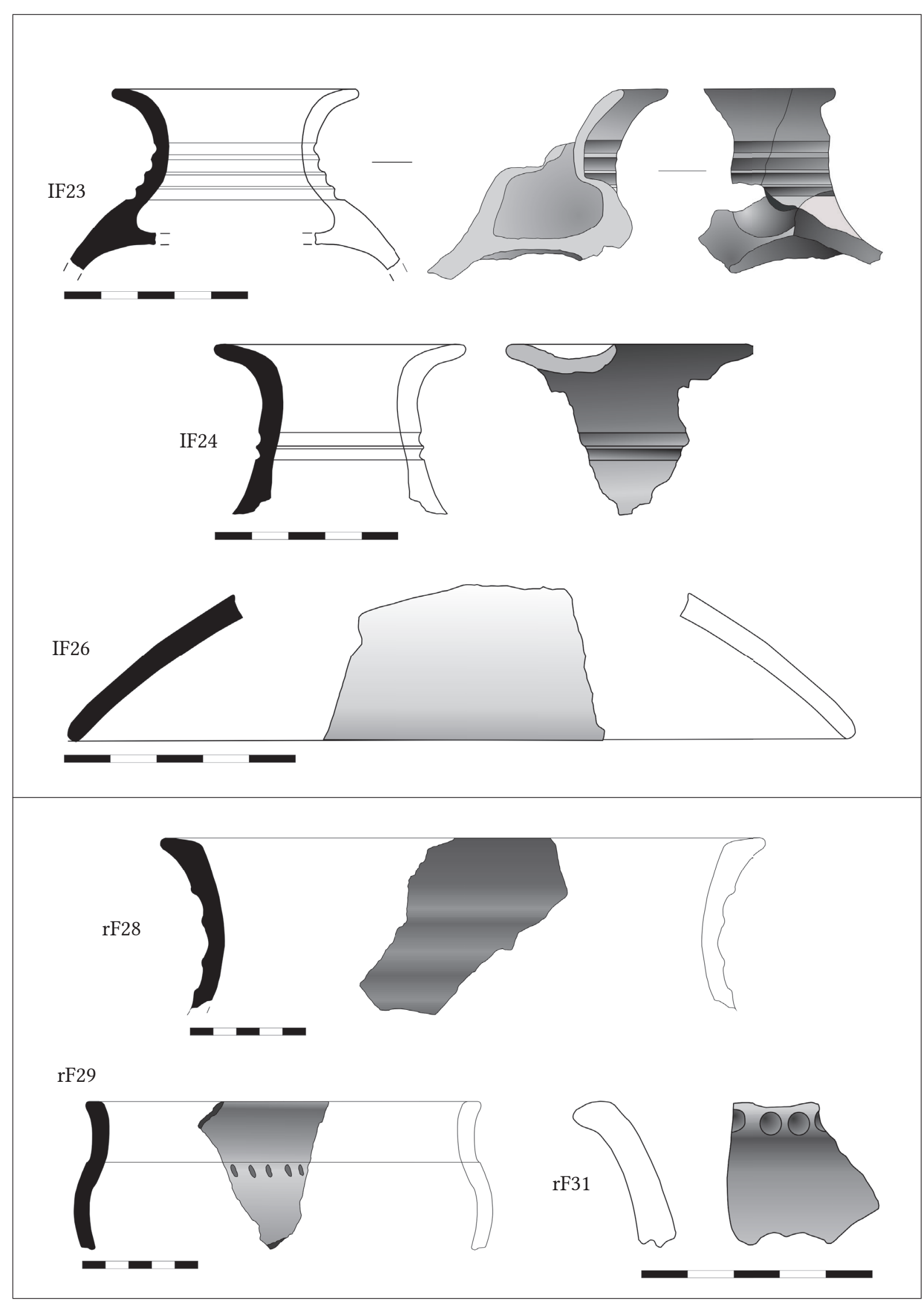

Fig. 27. Potteries of Tumulus 1. 


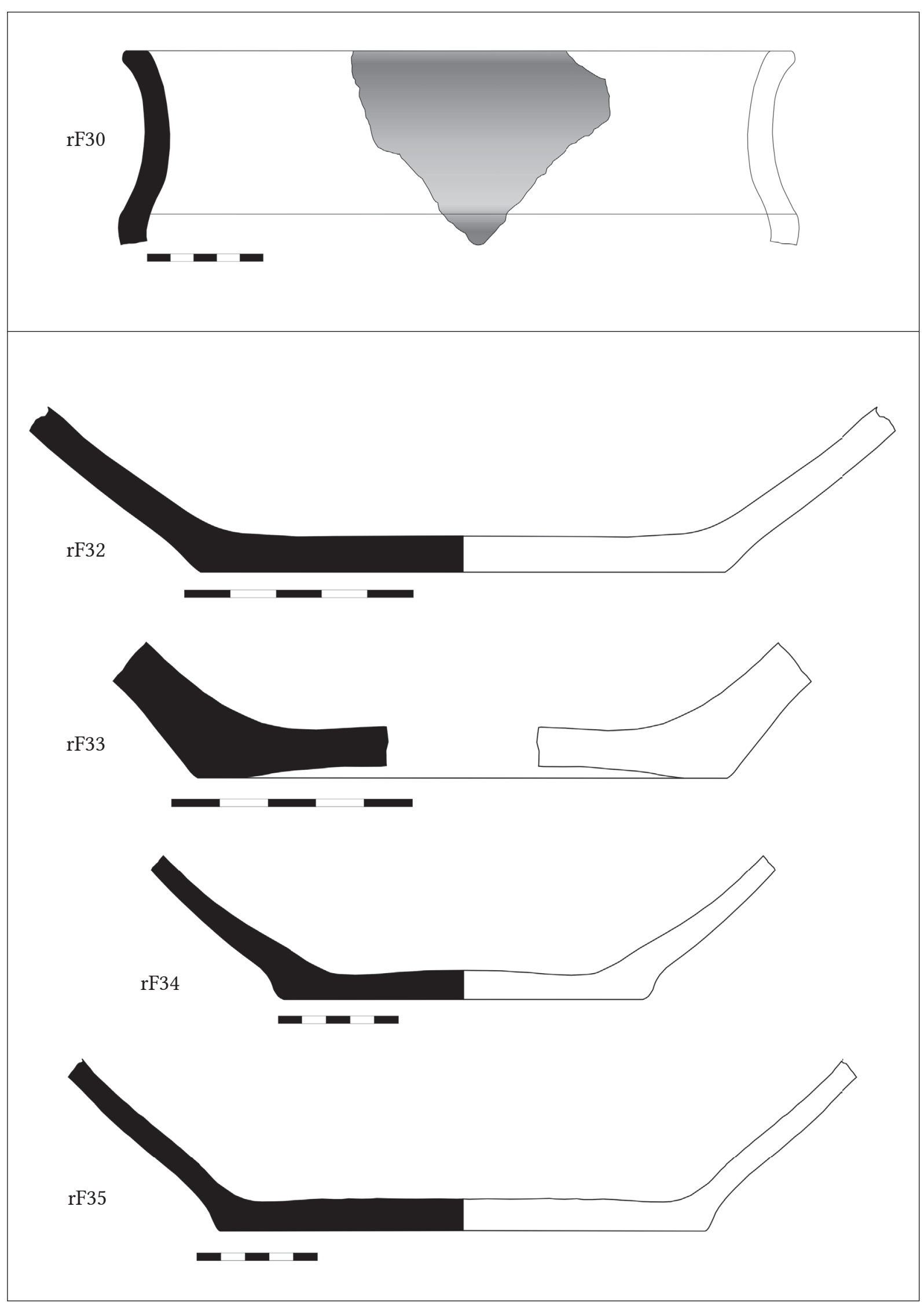

Fig. 28. Potteries of Tumulus 1. 


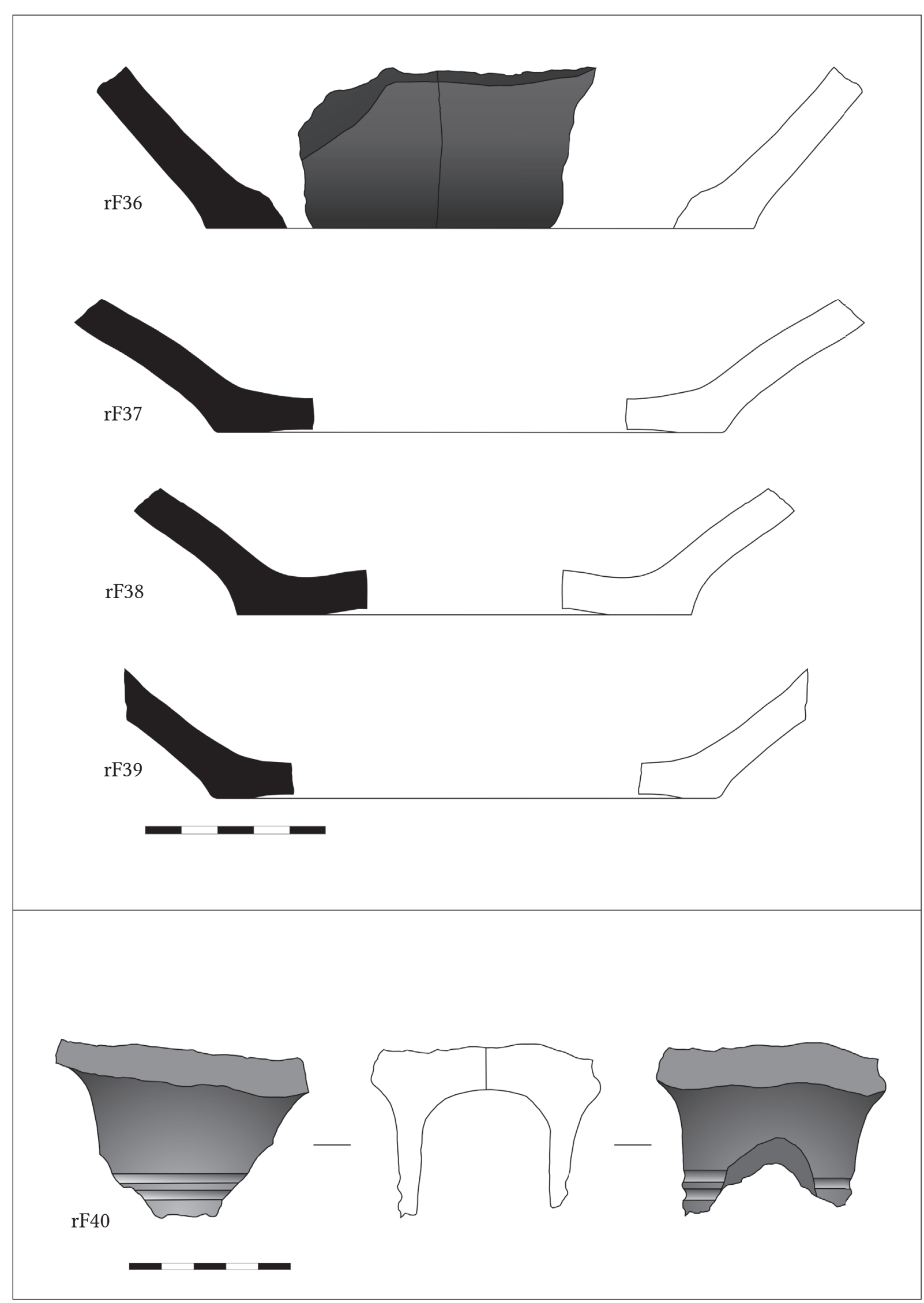

Fig. 29. Potteries of Tumulus 1. 
Bence Soós

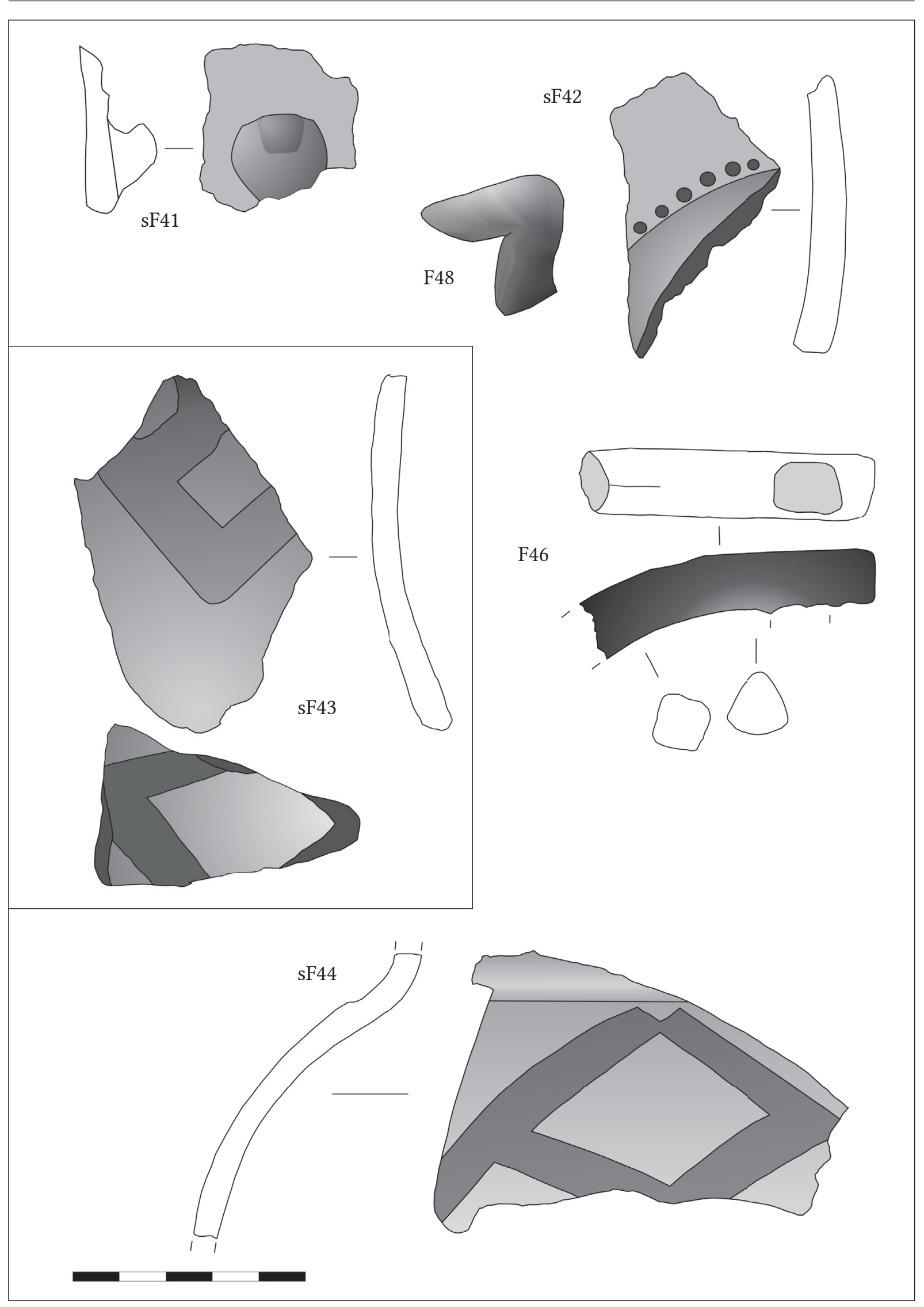

Fig. 30. Potteries of Tumulus 1.

204 


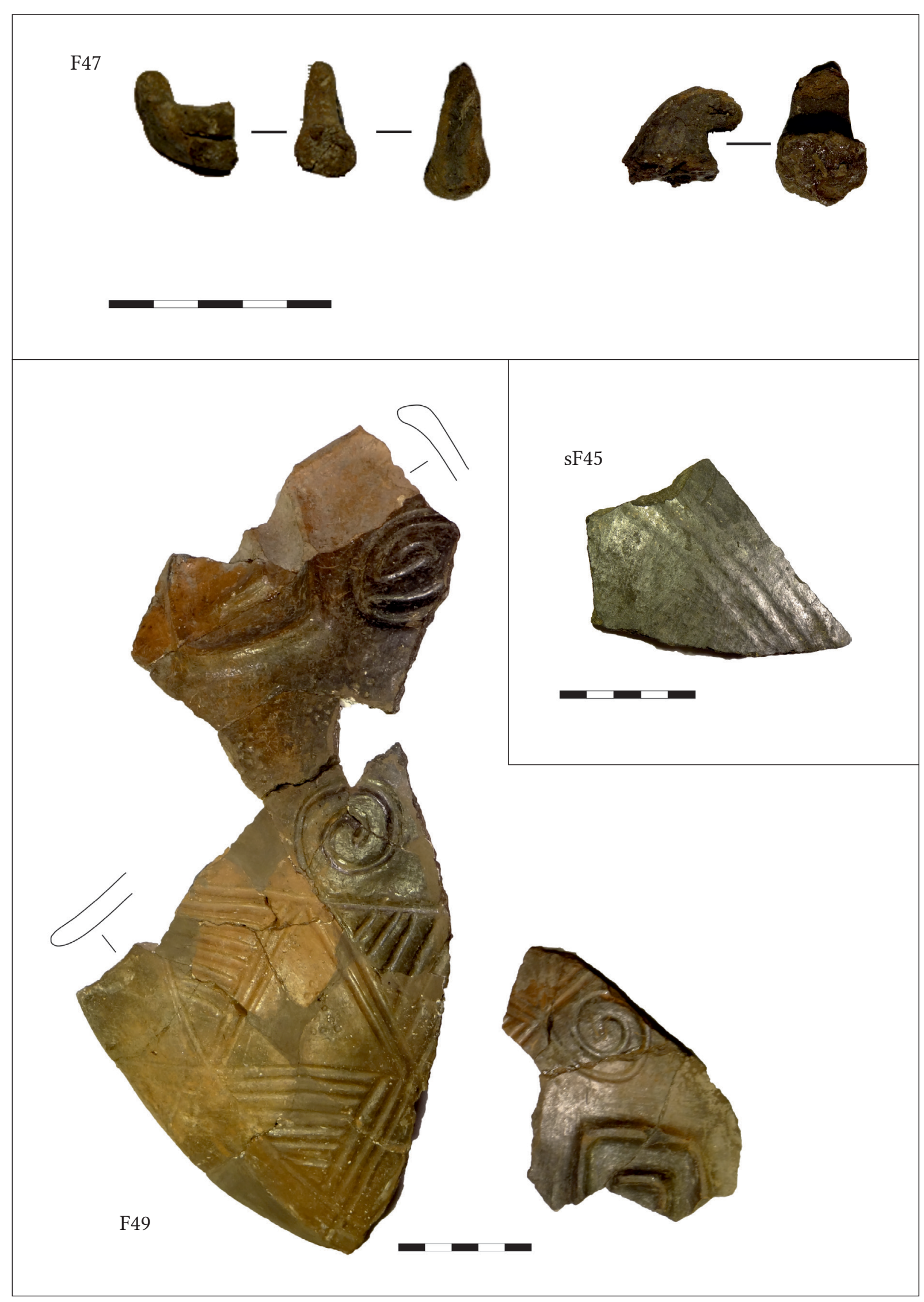

Fig. 31. Potteries of Tumulus 1. 

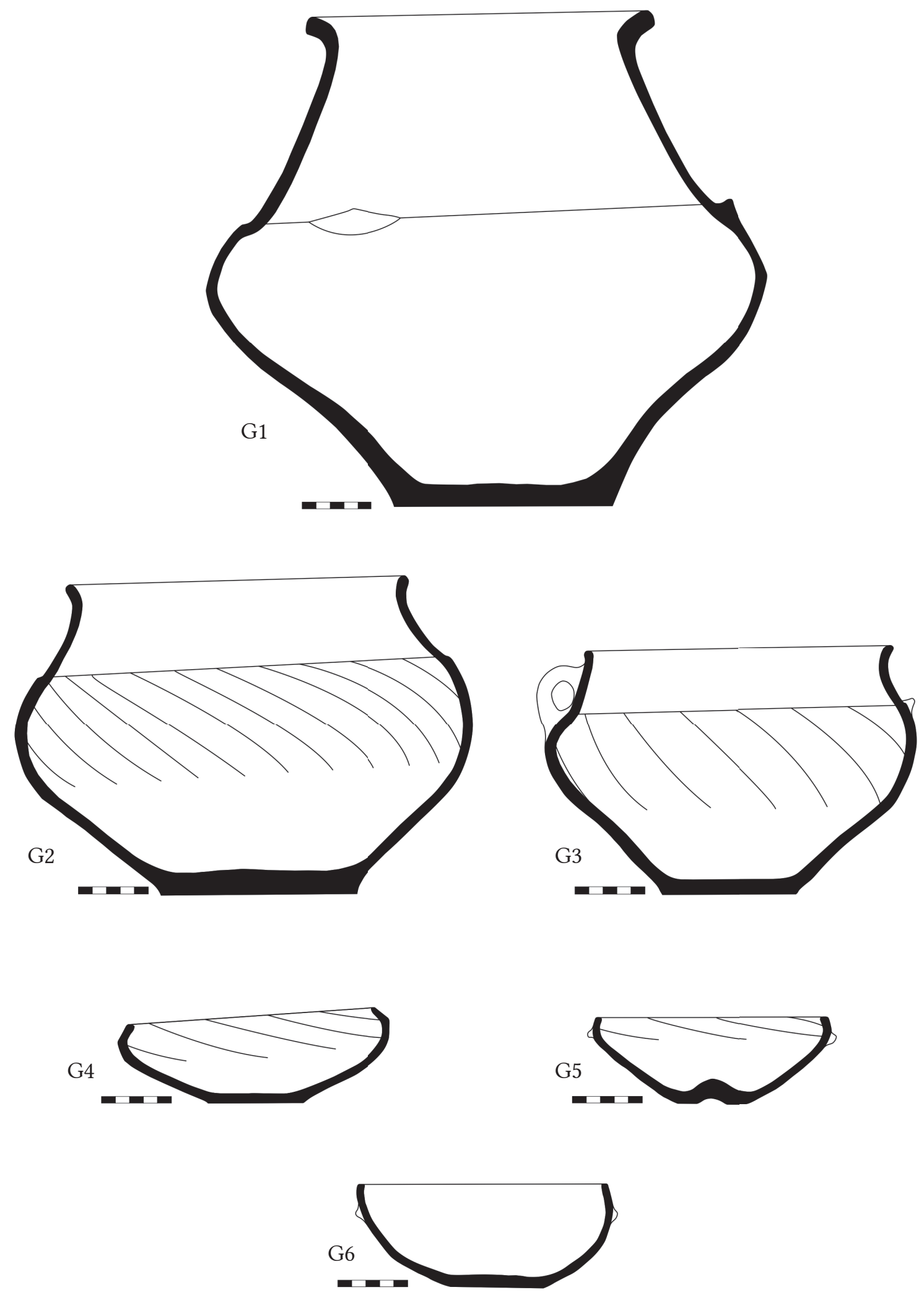

Fig. 32. Potteries of Tumulus 1. 